Leveling with Friends: Social Networks and Indian Farmers' Demand for a Technology with Heterogeneous Benefits

Nicholas Magnan, University of Georgia (corresponding author)

Department of Agricultural and Applied Economics

301 Conner Hall, Athens GA 30602

nmagnan@uga.edu / (706) 542-0731

David J. Spielman, International Food Policy Research Institute

Environment and Production Technology Division

2033 K St NW, Washington DC 20006

D.Spielman@cgiar.org/ (202) 862-5600

Travis J. Lybbert, University of California, Davis

Department of Agricultural and Resource Economics

One Shields Ave, Davis CA 95616

tlybbert@ucdavis.edu / (530) 554-1393

Kajal Gulati, University of California, Davis

Department of Agricultural and Resource Economics

One Shields Ave, Davis CA 95616

kgulati@ucdavis.edu / (530) 400-5769 


\title{
Leveling with Friends: Social Networks and Indian Farmers' Demand for a Technology with Heterogeneous Benefits
}

\author{
By Nicholas Magnan*, David J. Spielman ${ }^{\S}$, Travis J. Lybbert ${ }^{\ddagger}$, and Kajal Gulati ${ }^{\ddagger}$
}

\begin{abstract}
Agricultural technologies typically spread as farmers learn about profitability through social networks. This process can be nuanced, however, when net returns for some farmers may not be positive. We investigate how social learning influences demand for a resource-conserving technology in eastern Uttar Pradesh, India. We identify potential adopters through an experimental auction and randomly select a subset to adopt. We exploit this variation in adoption across networks to estimate network effects on demand for the technology one year later using a second auction. Technology benefits vary, and network effects are completely conditional on benefits. Having a benefiting adopter in one's network increased demand by over 50 percent, whereas having a non-benefiting adopter had no effect. These effects are strong enough to bring average demand in line with expected benefits. For many farmers, however, demand remains below the market price, suggesting that network effects will lead to increased-but not rapid widespread-adoption.
\end{abstract}

\section{JEL Codes: 013, 033, Q12}

Keywords: Agricultural technology, Benefit heterogeneity, Laser land leveling, Resource conserving technology, Social learning, Social networks

\footnotetext{
*Contact author, Department of Agricultural and Applied Economics, 301 Conner Hall, University of Georgia, Athens, GA 30602. Email: nmagnan@uga.edu. Phone: 706-542-0731; ${ }^{\S}$ Environment and Production Technology Division, International Food Policy Research Institute; ${ }^{\ddagger}$ Department of Agricultural and Resource Economics, University of California, Davis.
} 


\section{Introduction}

Technological innovation can make agriculture more productive and more profitable for the rural poor in developing countries and improve household food security among both producers and consumers. Yet, slow adoption, non-adoption, and dis-adoption of seemingly beneficial technologies remain a persistent concern. Such adoption puzzles have fueled decades of research in development economics to examine drivers of and barriers to technology adoption. Factors found to influence adoption include risk aversion (Feder 1980; Liu 2013); credit constraints; access to information about the availability, profitability, and use of new technologies (Besley and Case 1994; Conley and Udry 2010; Foster and Rosenzweig 1995; Munshi 2004); and heterogeneous benefits (Griliches 1957; Suri 2011).

Farmers frequently cite other farmers as their most trusted and reliable source of information regarding new technologies (Anderson and Feder 2007; Birner, et al. 2009). The empirical literature largely shows that farmers do indeed learn about the benefits and correct use of new technologies through their social networks (Bandiera and Rasul 2006; Cai, de Janvry and Sadoulet 2015; Conley and Udry 2010; Maertens 2013; McNiven and Gilligan 2012; Munshi 2004). ${ }^{1}$ Less is known, however, about the role of heterogeneous information in the social learning process. Such information heterogeneity may arise from differential adoption across networks, differential benefits among adopters, or both. For example, some farmers may not personally know anyone who has adopted a new technology, while others may be surrounded by early adopters. Alternatively (or additionally), for technologies with heterogeneous benefits, adopters' experiences can range from positive to neutral to negative, which introduces another dimension of information heterogeneity. Social learning processes are rich and nuanced because they are multidimensional in these ways: variation in the amount and type of information farmers receive through their social networks fundamentally shape social learning and

\footnotetext{
${ }^{1}$ To our knowledge two notable exceptions exist. Duflo, Kremer, and Robinson (2006) find no network effects on fertilizer among Kenyan farmers. In an instance outside of agriculture, Kremer and Miguel (2007) find that network effects on uptake of deworming medicine are negative among Kenyan schoolchildren.
} 
technology dissemination. These sources of information heterogeneity can pose particular challenges for researchers - a challenge we directly address in this paper.

While most existing studies on network effects do not account for information heterogeneity, those that do find that it plays an important role. Munshi (2004) finds that during the Green Revolution, social learning accelerated adoption of high-yielding varieties of a crop cultivated in areas of India with uniform growing conditions (wheat), but not for a crop cultivated in areas with heterogeneous conditions (rice), where information based on one farmer's experience is less relevant to others. Conley and Udry (2010) find that pineapple farmers in Ghana adjust the amount of fertilizer used towards amounts with which their contacts achieved good results and away from amounts with which their contacts achieved bad results, indicating that different information from networks leads to different behavior. In this analysis, we examine how social learning affects technology demand for a resource conserving agricultural technology - laser land leveling (LLL) - taking into account benefit heterogeneity. We do this using data from a field experiment conducted in three districts of eastern Uttar Pradesh (EUP), India.

Agronomic trials have demonstrated that LLL saves substantial irrigation water and reduces groundwater extraction costs (Jat, et al. 2006; Jat, et al. 2009), but custom hire LLL services had not yet arrived in EUP at the time of this study. This initial lack of a local market for LLL services - largely driven by small average landholdings, low investment levels, and low agricultural productivity in EUP relative to areas with pre-existing LLL markets - is an important prerequisite for our field experiment as it allows us to control the provision of LLL services over the course of the study. Since the conclusion of the study, private LLL service providers have expanded into EUP and farmer familiarity with the technology has spread beyond our study villages. While this subsequent diffusion of LLL in EUP has not been as rapid as more homogeneous places with higher productivity and larger plots, it nonetheless suggests that the 
technology is beneficial to at least a subset of EUP farmers. We examine how farmers in this more complex, heterogeneous setting learn about potential LLL benefits.

The field experiment we use in this study consists of two components: (1) a pair of binding experimental auctions for LLL custom service hire held one year apart, and (2) a lottery to determine who among the winners of the first auction would actually adopt the technology. The auctions capture demand for LLL before and after its introduction, allowing us to compare the benefits of LLL farmers perceive to actual benefits before and after any social learning takes place. The lottery generates exogenous variation in the number of adopters in each farmer's network, allowing us to circumvent the reflection problem (Manski 1993) and estimate network effects. This randomization also allows us to estimate the benefits of the technology within the sample.

Our results demonstrate some important nuances in how social networks drive technology adoption. On average, LLL reduced water use by 25 percent within the sample and appears to be profitable for 43 to 59 percent of farmers at the likely market price. However, in the first auction only two percent of farmers bid at or above this price, indicating that although the technology would benefit many farmers, these potential benefits were not widely-appreciated by farmers initially. We find strong evidence that farmers learned about LLL benefits over the course of the study, and their demand in the second auction reflects this. Having a benefiting in-network adopter increased WTP by over 50 percent, equivalent to a 32 percent subsidy of the likely market price. Adjusting initial demand for LLL by this mean network effect indicates that for 39 percent of farmers network effects could incite adoption. However, not all farmers receive this network effect because networks are sparse and the technology is not profitable for all farmers. Consequently, we calculate that in a village where 12 percent of farming households initially adopt LLL at a discounted price, network effects would initially increase adoption by 9 percent. 
The paper is organized as follows. In Section 2 we provide some background information on LLL, particularly its use in India. In Section 3 we discuss our study setting and experimental design. In section 4 we calculate the profitability of LLL within our sample and explore reasons why a private market for LLL services did not exist at the time of the study. In Section 5 we estimate network effects econometrically and combine our findings on social learning with those on benefits to explain slow diffusion. In Section 6 we offer a postlude on LLL markets in the study area and conclude.

\section{Background: Laser Land Leveling in India}

LLL is a resource conserving technology. In the flood-irrigated rice-wheat systems of the Indo-Gangetic Plains (IGP), 10-25 percent of irrigation water is lost because of poor management and uneven fields (Jat, et al. 2006). Uneven fields can also lead to inefficient use of fertilizers and chemicals, increased biotic and abiotic stress, and diminished yields (Jat, et al. 2006). Farmers in this region, like most farmers around the world, have long recognized that level plots are easier to cultivate and more efficient than uneven plots. In response, they have devised techniques to address this such as building contoured levees and manually leveling with planks. The main difference between traditional practices and LLL is precision. LLL uses a stationary emitter to project a laser beam above a plot. A receiver on an adjustable drag scraper captures the beam, and signals to the tractor operator where to remove and relocate soil. Whereas traditional leveling methods have a leveling precision of $\pm 4 \mathrm{~cm}$ (best case) to $\pm 15 \mathrm{~cm}$ (worst case), LLL can level plots to a precision of $\pm 1 \mathrm{~cm}$ (Jat, et al. 2006; Jat, et al. 2009).

In India, LLL was first introduced in western Uttar Pradesh in 2001. Since then, the technology has achieved widespread acceptance in some areas of the IGP, notably in the agriculturally progressive Indian states of Haryana and Punjab. LLL is typically obtained through custom service hire agreements. Since the introduction of LLL in India an estimated 10,000 LLL units have leveled one million hectares (Jat 2012). LLL benefits farmers primarily by reducing water use. Agronomic trials in rice-wheat systems in 
this region have found that LLL results in 10-30 percent irrigation savings (Jat, et al. 2006; Jat, et al. 2009). This is particularly important in the IGP, where farmers still rely on flood irrigation, which requires them to irrigate until the highest point of the field is visibly submerged. Consequently, groundwater is being extracted at increasingly unsustainable rates. Although Indian farmers do not pay unit charges for groundwater, in EUP the vast majority use diesel pumps to irrigate and therefore can reduce fuel costs by saving water.

In some instances LLL has been found to improve crop establishment and growth, thereby increasing the efficiency of fertilizers, deceasing weed pressure, and increasing production. Agronomic trials have shown a 6-7 percent increase in nitrogen use efficiency, which could lower the need for fertilizer, a 1.5-6 percent increase in effective farming area, and a 3-19 percent increase in yield (Jat, et al. 2006). In addition to providing private benefits to adopting farmers, LLL provides public benefits in the form of reduced groundwater depletion, nutrient and chemical runoff, and hydrocarbon use. Jat et al. (2006) estimate that extended use of LLL to 2 million hectares of rice-wheat land in the IGP could save 1.5 million hectare-meters of irrigation water, 200 million liters of diesel, and reduce greenhouse gas emissions by 0.5 million metric tons over three years.

In contrast to the more agriculturally developed regions of India where LLL has taken hold, LLL is extremely new to the more heterogeneous and much poorer EUP region. We will discuss some reasons for this later in the paper. The fact that LLL was essentially unheard of in EUP at the onset of our study is crucial for our experiment because it ensures that study farmers had no market price information about LLL and could only learn about the technology by observing and interacting with farmers who are also part of the study.

\section{Experimental Design and Data Collection}

\subsection{Study site and sample}


The state of Uttar Pradesh (UP) is poor and highly agrarian; 70 percent of the population lives in poverty (Alkire and Santos 2010), and EUP is relatively poor compared to the rest of the state. Farmers cultivate rice during the summer kharif season when the monsoon provides much of the water needed for irrigation, and wheat in the winter rabi season when the crop depends more on irrigation. Unlike areas in the western IGP where canals are a significant source of irrigation water, EUP depends almost exclusively on groundwater extracted by diesel, rather than electric, pumps.

Our study began prior to the onset of the kharif season in March 2011, continued through the 2011/12 rabi season (approximately October 2011 to May 2012), and concluded during the subsequent kharif season in July 2012. We selected three districts-Maharajganj, Gorakhpur, and Deoria-to represent heterogeneity in farm size and productivity in the rice-wheat cropping system of EUP. ${ }^{2}$ In each district we randomly selected four villages from among those with a population of at least 48 households and less than 400 households. We set the lower limit to ensure there would be at least 20 farming households to participate in the study, and the upper limit to avoid incomplete village rosters and the possibility that we would not capture any network links within a village. For each district, a population of 400 households per village is greater than the $90^{\text {th }}$ percentile of all villages.

To be sure that our intervention would be the only available source of information about LLL we excluded villages within a 10-kilometer radius of any LLL demonstrations, as well as any villages where related promotions of other resource-conserving technologies had been conducted. ${ }^{3}$ In the final sample only six farmers (1.2 percent of the sample) reported ever hearing of LLL, two farmers reported ever

\footnotetext{
${ }^{2}$ The sample selection criteria ruled out villages and households cultivating in flood-prone areas with no rice production during the kharif season. The sample selection did not, however, exclude villages and households where other crops were cultivated alongside wheat and rice.

${ }^{3}$ Following consultations with individuals involved in agricultural research, local extension services, and farm equipment sales and custom hire, we were able to pinpoint demonstrations of LLL and related resource-conserving technologies in EUP. Only three sources of LLL demonstrations were identified: sites selected by the Cereal Systems Initiative for South Asia (CSISA), of which this study is a part; the Krishi Vigyan Kendra (KVK) center in Kushinagar, a technology promotion unit of the Indian Council for Agricultural Research; and one private service provider working in partnership with CSISA.
} 
seeing LLL machinery, one farmer reported ever using LLL, and one farmer reported knowing the market price of LLL custom hiring. ${ }^{4}$

For each of the 12 selected villages, we randomly chose a paired village along a five-kilometer radius that met the same population criteria and was not within 10 kilometers of another previously selected village. Villages were selected in pairs to assess the reach of social networks across villages. Within each village, we randomly selected approximately 20 farmers from those cultivating plots of at least 0.2 acres (the minimum sized plot for LLL) to be included in the study. ${ }^{5}$ The resulting sample totaled 478 farmers. We found that only 39 farmers in the entire sample knew a sample farmer from a paired village, and only four discussed agriculture with one. We include these rare inter-village links in farmers' networks for our analysis, but do not distinguish them from intra-village links due to their low frequency.

\subsection{Experiment and data collection}

In each village the study unfolded as depicted in Figure 1. First, we conducted a scripted information session to introduce the sample farmers to LLL (1). Next, we conducted a survey featuring questions about network connections with other sample farmers, water use in the previous year, and household and farm characteristics (2-3). We then conducted an experimental auction to measure demand for the technology (4). Immediately following the auction, we used a lottery to determine who in the pool of qualifying farmers would actually receive and purchase LLL services (5). Soon after we hired four LLL teams (one tractor operator and one assistant) to provide leveling services to farmers who won the lottery (6), as well as four enumerators to monitor the provision of LLL services.

During the kharif (summer) rice season and the rabi (winter) wheat season we conducted intraseasonal surveys at approximately three-week intervals coinciding with major activity phases of the

\footnotetext{
${ }^{4}$ We believe that the single instance of a farmer reporting to have used LLL is an instance of misreporting or enumerator error.

${ }^{5}$ The intended sample size for each village was 24 , with an additional 12 replacement farmers pre-selected in case of absenteeism or lack of a large enough plot among the original 24 farmers.
} 
cropping season to collect detailed data on input use and exposure to LLL (7). At the end of these two growing seasons we conducted an endline survey, which included retrospective questions on irrigation since the beginning of the intervention (8), and a second LLL auction (9). To conclude the study we again hired two LLL teams to provide leveling services to farmers who won the second auction (10). We discuss these steps in more detail below.

[Figure 1 about here]

Information session (1): To introduce farmers to LLL we held a scripted information session in each village, and ensured the sessions were as consistent as possible across villages. The information session lasted approximately one hour, and included a talk by a lead member of the enumeration team; a video screening of a laser land leveler operating on a field, an interview with a service provider, and an interview with an LLL recipient; and a live question-and-answer session with a progressive farmer from EUP (but outside the study area) who previously received LLL services as part of a separate demonstration. During the information session, the team photographed all sample farmers. These photos were compiled into a composite picture for each village to be used later to help farmers identify their network links. At the conclusion of each information session, the team gave farmers illustrated brochures about LLL along with the range of bids they could make in the auction.

Naturally, farmers at each information session inquired about the price of LLL services. Because the information session was a precursor to an experimental auction, the enumeration team answered questions consistently and in a manner intended to prevent participants from anchoring their bid on a particular price. Specifically, the enumeration team explained that in recent years the market price ranged from Rs. 400 to Rs. 800 per hour of LLL service in states where services were available. ${ }^{6}$ This range is well above the market price of traditional leveling services, which ranged from Rs. 200 to Rs. 300 at the time of the study.

\footnotetext{
${ }^{6}$ During the study period the exchange rate was approximately 45 Indian rupees (Rs.) for one US dollar.
} 
Survey and social networks (2-3): Next, the team conducted surveys with sample farmers to collect data on farm and household characteristics, including retrospective irrigation data at the plot level for the agricultural year leading up to the study (2010/2011). The survey featured a social networks module that used the composite picture described above to help farmers identify their network contacts.

Before presenting how we define social networks for this study, it is useful to briefly describe the definitions used in other studies. In some cases, farmers' social networks have been defined as the entire village (Besley and Case 1994; Foster and Rosenzweig 1995; Munshi 2004). While using the village as the relevant social network captures many if not all of a farmer's contacts, it also captures many that are not in the farmer's network (Babcock and Hartman 2010; Maertens and Barrett 2012). In some cases it is possible to use observable variables from existing survey data, such as caste or religion, to refine what farmers' social networks are likely to be (Munshi and Myaux 2006). This method relies on strong assumptions regarding social interactions that may not be appropriate in some cases. For instance, we find that farmers in our sample have agricultural information contacts from different wealth and education classes, castes, and age groups.

Other studies have elicited farmer network links directly. Enumerators ask respondents about their specific interactions with others, i.e., who they trust, consider a friend, communicate with, or exchange information with. In some cases this is done in an open-ended manner, e.g., asking the respondent to list all people they talk about agriculture with. In other cases, respondents are asked to identify their network contacts from a partial or full list of others in the sample (Conley and Udry 2010; Maertens 2013; McNiven and Gilligan 2012), e.g., to identify the other sample individuals with whom they talk about agriculture with. Once each individual's connections are determined, links can be classified as unidirectional ( $B$ is in A's network if A claims B), bidirectional ( $B$ is in A's network if A claims B or B claims A), or reciprocal (B is in A's network if A claims B and B claims A). 
We elicit network links directly from sample farmers by asking them about their connections to all other study farmers. Enumerators presented the composite photo of sample farmers in a subject's own village and asked a series of yes or no questions about respondents' relationships with the other farmers in the picture, e.g., "Are any of these farmers your friends?", "Are any in your family?", "With which of these farmers do you discuss agriculture?", and "Which of these farmers do you consider progressive?". The same exercise was then conducted using a composite picture of sample farmers in the paired village.

For our main analysis we define the relevant social network as the farmers with which the respondent discusses agriculture. We use unidirectional links because information is more likely to flow from the farmer claimed as an agricultural contact to the farmer claiming him rather than in the opposite direction, especially if link formation is strategic (Jackson and Wolinsky 1996). ${ }^{7}$ In Section 5.5 we present results generated using friendship and family linkages and using bidirectional linkages.

Experimental Auction and Lottery (4-5): Several days after the information session and baseline survey, the enumeration team gathered all of the sample farmers in a given village for an experimental auction to elicit their demand for LLL. We used a Becker, DeGroote, and Marschak (1964)-style auction in which farmers were asked, in secrecy and plot by plot, "would you pay Rs. X per hour to have this plot laser leveled?" for increasing values of X. Possible values were Rs. 0, 250, 300, 350, 400, 450, 500, 550, 600, 700, and 800 per hour. When a farmer said he would not pay Rs. X, the facilitating enumerator would move to the next plot. This type of auction is non-competitive; farmers bid against an unknown price in an envelope that is the same for everyone in the village, not against other participants. It is also incentive compatible, as the farmer does not pay his declared WTP for LLL, but the price in the envelope

\footnotetext{
${ }^{7}$ Such asymmetric information flow is consistent with the motivation underlying agricultural extension practice, in which a progressive farmer plays a central role in sharing information with others farmers. In our sample of linkages where A claimed B as an agricultural contact, A was a progressive farmer 41 percent of the time and B was a progressive farmer 81 percent of the time.
} 
(provided his bid meets or exceeds it). We consider the maximum value the farmer bid for any plot to be his maximum WTP, which is the value we use in our analysis.

Just before the final price was drawn, the lead enumerator informed all participants that we would not be able to provide LLL services to all auction winners because of capacity constraints. Consequently, we would use a public lottery immediately following the auction to determine who would actually pay for and receive LLL custom hire services. Auction winners would have a 50 percent chance of winning the lottery. Farmers were very understanding of the process and accepted lottery outcomes without issue. The presence of the lottery does not change the optimal bidding strategy, which is to bid one's true WTP for LLL services, which should reflect the farmer's perceived benefits of the technology. To ensure that the majority of farmers entered the lottery, in each village Rs. 250 was drawn as the purchase price. ${ }^{8}$ Approximately two-thirds of farmers won the auction. To increase variation in LLL demand and correlated covariates among those actually receiving LLL services, we stratified farmers by their maximum WTP immediately before the lottery. The full auction protocol can be found in Appendix A.

The auction/lottery mechanism resulted in a trifurcation of participants: (1) auction losers, (2) auction winners but lottery losers, and (3) auction and lottery winners. We define auction losers as 'nonadopters'. We define the set of auction winners/lottery losers and auction/ lottery winners as 'qualifying farmers' and define the subset of auction winners/lottery winners as 'adopters'. We expect auction losers to systematically differ from qualifying farmers due to self-selection, and this is indeed the case. Using t-tests we find that qualifying farmers have 20 percent more years of schooling, 60 percent greater landholdings, and are generally wealthier (as measured by a factor analytic wealth index) than

\footnotetext{
${ }^{8}$ Although the price was pre-selected by the enumeration team to be Rs. 250, this price was unknown and effectively random to participants. In one village Rs. 300 was selected and in another village Rs. 350 was selected, before it became clear a lower price was needed to bring enough farmers into the lottery. Subsequently Rs. 250 was selected in all other villages.
} 
farmers who lost the auction. ${ }^{9}$ Because auction winners are split into lottery winners and losers at random there should no systematic difference in age, education, landholdings, wealth, and WTP between the two groups, and we find this to be true (Table 1).

[Table 1 about here]

Technology delivery, intra-seasonal surveys, and endline surveys (6-8): Lottery winners were required to pay for and receive LLL services at the drawn price at a mutually agreed-upon date during the months immediately following the auction. The timing of the auction was such that LLL would be provided to lottery winners during the 100-day fallow season between the rabi (winter) wheat season and the kharif (summer) rice season, which is effectively the only time farmers have to receive such services. Service provision during this time was carefully monitored to ensure that farmers had no other access to LLL services, e.g., through side selling by the service provider or by other research or extension projects operating in EUP. At the time of provision, enumerators worked with service providers to collect data on how long it took to level each plot.

Over the course of the next year the enumeration team conducted intra-seasonal surveys with all sample farmers at intervals corresponding to major activity phases of the growing season. These surveys included questions on input use, including irrigation, and on farmers' exposure to LLL through other sample farmers. We use the irrigation data to estimate average water use and diesel cost savings for LLL adopters, which we find to be 23 and 24 percent $(p<0.05)$, respectively, compared to the status quo (Lybbert, et al. 2014). To capture farmer exposure to LLL enumerators asked: "With whom have you discussed agriculture with since the auction?", "With whom have you discussed LLL in particular?", "Whose fields did you see the LLL equipment operate on?", and "Whose fields have you seen?".

\footnotetext{
${ }^{9}$ The wealth index consists of house condition; ration card possession; landholdings; and ownership of cell phones, vehicles, TVs, a satellite dish, and livestock. We tried several variations of this index and saw no differences in results.
} 
The spring rice harvest of 2012 marked the end of one full agricultural year following the introduction of LLL. At this point we conducted an endline survey with all sample farmers to collect, among other things, retrospective data on irrigation for the agricultural year following the introduction of LLL (2011/2012). We use this data to calculate water saving at the individual level, as the irrigation data collected during the intra-seasonal survey does not allow for this. Using this pre- and postintervention data to estimate average water savings, we achieve point estimates similar to those estimated using the data from the intra-seasonal data, although with less precision.

Follow-up auction (9): In Spring 2012 we collected demand data using a second auction identical in structure to the first, but without a lottery so that all farmers who bid high enough would receive and pay for LLL custom hire services. Using WTP data from an experimental auction instead of binary adoption data at a given price offers several advantages. First, we are not limited to testing whether network effects push farmer demand across a single price threshold. Because we have a more continuous measure of demand we can estimate network effects on adoption at a variety of prices. Furthermore, because we can measure demand changes in monetary terms we can directly compare them to the estimated benefits of the technology, to the market price, and to potential discounts or subsidies.

\section{Benefit Heterogeneity and LLL Demand}

Consistent with the classic technology diffusion model (Griliches 1957), LLL first gained widespread acceptance in India in highly fertile and agriculturally progressive western IGP, where the technology would be most beneficial due to a low water table and large plots (Jat, et al. 2009; National Remote Sensing Centre 2014). Because farms are large in the western IGP, a small number of farmers or farmer groups had enough land to justify purchasing their own LLL equipment after its release, which ultimately catalyzed LLL services markets. With far fewer large farms in EUP, these markets have been slower to emerge. Moreover, the profitability of custom hire LLL service provision is more uncertain in EUP. In the 
standard business model, LLL is priced per hour of leveling time; the provider is not compensated for transportation or preparation time. In areas where plots are small and dispersed, such as EUP, these costs could be substantial, particularly if demand is low. Providers generally travel from village to village and provide LLL to farmers who want it-and can pay cash on the spot-without making arrangements ahead of time. In short, service providers expanding into EUP initially face more uncertainty about demand for LLL and therefore their ability to be fully employed for an entire season than in the western IGP.

Our data indicate that such hesitation by LLL service providers may be warranted. Average WTP in the first auction (WTP 1 , hereafter) was Rs. 204 per hour and, among the farmers with nonzero WTP, Rs. 322 per hour. $W T P_{1}$ was only at or above the likely market price of Rs. 500 per hour for 3.7 percent of farmers. Initial demand may be low because farmers are poor and liquidity constrained, have high discount rates, or farm under conditions for which LLL is not profitable. Once farmers learn that LLL is available in their area, three possible situations can unfold: (1) LLL is beneficial, and farmers do not initially know this but learn from early adopters. (2) LLL is beneficial, but farmers do not learn this from early adopters, (3) LLL is not beneficial (in which case it does not matter if farmers learn because this is what they initially believe). Under the first scenario, we would expect $W T P_{1}<$ price $\leq$ benefits $=$ WTP in the second auction $\left(W T P_{2}\right.$, hereafter $)$. Under the second scenario, we would expect that $W T P_{1}=W T P_{2}<$ price $\leq$ benefits. Under the third scenario, we would expect $W T P_{1}, W T P_{2}$, and benefits < price. In the remainder of this section we examine whether LLL is profitable. In Section 5 we turn our attention to the extent to which farmers learn that it is profitable.

LLL benefits come mostly from having to irrigate less. In a related paper we compare irrigation spending by farmers who adopted LLL to those who wanted to adopt, but lost the lottery, and find average diesel cost savings to be Rs. 383 per acre (Lybbert et al. 2014). We do not have adequate 
statistical power to estimate secondary benefits (increased yields, decreased fertilizer and chemical use, and decreased weed pressure), so we omit them from our calculations and consider this estimate to be conservative. To convert diesel savings from Rs. per acre to Rs. per hour-the unit by which LLL is normally priced-we divide diesel cost savings by how long it took to level (per acre) each farmer's land ( 3 hours per acre on average) yielding Rs. 161 per hour for a single agricultural year. These savings are in comparison to whatever farmers would have spent to level their plots had they not received LLL. While we do not know if farmers who lost the lottery leveled their fields by another method in 2011, we do know that most sample farmers periodically do: 71 percent reported using a traditional leveler and 87 percent reported using another method (typically leveling with a plow) in the past. At the time of the study, the market price of traditional leveling ranged from Rs. 200 to Rs. 300 per hour. To get a very conservative estimate of the average cost of leveling for those who did not receive LLL, we attribute zero costs to using a plow and a cost of Rs. 200 per hour to using traditional leveling equipment to obtain a weighted non-LLL leveling cost of $0.71 \times$ Rs. $200=$ Rs. 142 per hour. Assuming leveling is done every four years, the per-year cost of traditional leveling is Rs. 36 per hour. Adding this to the costsavings per hour of LLL service yields a total savings of Rs. 197 per hour for a single year.

The single year benefits we calculate are well below the market price of LLL. However, LLL benefits last more than one year. Farmers who use LLL generally have their plots leveled every three to five years. Because agronomic studies of LLL are limited to one or two years, little is known about how LLL benefits depreciate (Jat, 2009). An extremely optimistic scenario is one where benefits do not depreciate over the useful life of the technology, which we assume is four years, and immediately go to zero afterward. A more conservative scenario is one where benefits depreciate linearly to zero over the useful life of the technology. To establish a range of benefits we consider both scenarios. Under the optimistic depreciation scenario, single year benefits of Rs. 198 per hour of LLL translate to a benefit stream of Rs. 792 per hour. Under the conservative depreciation scenario, the benefit stream is Rs. 495 
per hour. Discounting benefits using a 20 percent discount rate yields a benefit stream of Rs. 653 per hour under the optimistic scenario and Rs. 428 per hour under the conservative scenario. ${ }^{10}$

Under the optimistic scenario, the benefits exceed the likely market price of LLL (Rs. 500), whereas under the conservative scenario they are close to, but below, the likely market price. It is therefore unlikely that LLL would be beneficial for all farmers in our sample at the market price, but it would be for some farmers. To estimate the proportion of sample farmers who would benefit from purchasing LLL at the market price, we calculate the percent diesel cost savings necessary to achieve a benefit stream of Rs. 500 per hour of leveling. ${ }^{11}$ Using retrospective pre- and post-intervention irrigation data, we determine the number of LLL adopters in our sample that meet or exceed this level of savings under each of the scenarios described above. Under the optimistic scenario with no discounting, farmers need to save 14 percent of diesel costs for LLL to be profitable, under the optimistic scenario with discounting they need to save 22 percent, under the conservative scenario without discounting they need to save 26 percent, and under the conservative scenario with discounting they need to save 35 percent. We find that 59 percent of farmers would benefit under the optimistic scenario with no discounting, 56 percent under the optimistic scenario with discounting, 53 percent under the conservative scenario without discounting, and 43 percent under the conservative scenario with discounting. Table 2 contains estimated LLL benefits under different depreciation and discounting scenarios.

Data from the second auction correspond to a scenario of heterogeneous benefits with at least some learning. Mean $W T P_{2}$ was Rs. 310, and Rs. 382 for those with $W T P_{2}>0$, so that: $\overline{W T P}_{1}<\overline{W T P}_{2}<$ benefits $_{\text {conservative }}<$ price $_{<}<$benefits $_{\text {optimistic }}$. On average, LLL demand was still below

\footnotetext{
${ }^{10}$ For discounting, we consider two distinct points in time to receive benefits: in the middle of the rice season (approximately 4 months after leveling) and in the middle of the wheat season (approximately 9 months after). We split water savings 60 to 40 wheat to rice, reflecting the split we find in the data.

${ }^{11}$ We thank an anonymous referee for suggesting this.
} 
the market price one year after its introduction. However, looking at individual demand we find that $W T P_{2} \geq 500$ for 14.2 percent of farmers. This change in demand, combined with our benefit estimates, suggests that some farmers learned from early adopters that LLL is beneficial at market prices. In the next section we examine in detail how learning affects demand.

\section{Network Effects and LLL Demand}

Farmers likely exhibited low demand for LLL before its introduction because they did not know the benefits. Demand was substantially and significantly $(p<0.01)$ higher in the second auction, although mean $W T P_{2}$ was still below the market price. While the increase in demand suggests social learning, we cannot conclude this is the case without further analysis; a number of factors could lead to changes in demand from one year to another. In this section we estimate network effects using our experimental data, and investigate whether they are large enough to incite adoption at likely market prices. We do so with and without taking into account differences in the water savings early adopters experienced in order to examine the role of benefit heterogeneity on social learning.

\subsection{Econometric model}

To identify network effects we randomize LLL adoption among farmers who want to adopt, as revealed by $W T P_{1}$. A farmer receives an LLL network 'treatment' if he has at least one first-generation adopter (lottery winner) in his network. For outcomes, we are interested in demand for the technology after the introduction of LLL $\left(W T P_{2}\right)$ and different ways by which farmers are exposed to LLL through their networks. If we estimate the model:

$$
y_{i}=\alpha+\beta_{1} \cdot \text { adopter }_{i}+\eta_{i}
$$

and adopter $_{i}$ and $\eta_{i}$ are correlated, we will face an endogeneity problem. For instance, a farmer may have high demand for LLL and also have many contacts that qualified for the lottery-and therefore a 
high probability of having an adopting farmer in his network-without a causal impact of the latter on the former. To demonstrate that our lottery mitigates the problem, we decompose the error term as:

$$
\eta_{i}=\beta_{2} \cdot \text { qualifying } i
$$

where $\eta_{i}$ is a function of the number of qualifying farmers in farmer i's network and a remaining error term $\varepsilon_{i}$. We combine the two above equations to yield our base econometric model, adding controls for total network size and other observable variables (such as farmer age, education, wealth index score, and $W T P_{1}$ ) to potentially improve precision:

$$
y_{i}=\alpha+\beta_{1} \cdot \text { adopter }_{i}+\beta_{2} \cdot \text { qualifying }_{i}+\beta_{3} \cdot \text { networksize }_{i}+X_{i}^{\prime} \beta_{4}+\varepsilon_{i} \text {. }
$$

We can estimate the network effect $\beta_{1}$ without bias if the variable qualifying ${ }_{i}$ is the only reason why $\eta_{i}$ and adopter $_{i}$ are correlated (i.e., the conditional independence assumption is satisfied). We know this is the case because adopter $_{i}$ is only a function of qualifying $i$ and random lottery draws. This econometric approach is consistent with that used by Kremer and Miguel (2007) and Oster and Thornton (2012). The model in (1) treats social learning from farmers that benefited from LLL and farmers that did not equivalently. We therefore consider the network effects we estimate using (1) to be 'unconditional'.

We can treat adopter as a binary variable for the presence of at least one adopter or as a continuous variable for the number of in-network adopters (which ranges from one to three). Network links in our sample are somewhat rare. Farmers identified 0.71 agricultural information contacts in their village on average out of roughly 20 potential contacts. ${ }^{12}$ The overwhelming majority of farmers reported either zero or one agricultural contacts in the sample, and only three farmers reported having five or more agricultural contacts. Friends and family linkages were more common: farmers claimed 1.14

\footnotetext{
${ }^{12}$ On average, there are 105 farming households in each village, so farmers have approximately 3.5 agricultural information contacts in their village on average.
} 
friends or family members on average and 16 farmers reported having five or more friends or family members in the sample. ${ }^{13}$ Figure 3 shows histograms of network size variables.

[Figure 3 about here]

For this reason, we test the impact of having at least one in-network adopter in our main analysis. Doing so facilitates interpretation and accounts for the likelihood of quickly decreasing marginal effects of additional in-network adopters. While the existence of decreasing marginal effects is ultimately an interesting empirical question, it is one we cannot answer adequately with our data; the continuous variable for the number of adopting contacts and the dichotomous variable for having at least one adopting contact are 92 percent correlated. Consequently, when we estimate network effects using a series of binary variables for the number of in-network adopters we cannot identify impacts of having more than one (Appendix B). Results using continuous values for the total number of adopters are available in Appendix C.

There are also two ways to formulate the qualifying variable, which controls for the number of in-network farmers that bid high enough in the auction to enter the lottery to receive LLL. One possibility is to treat it as a continuous variable. Doing so is problematic because of the nonlinear relationship between the number of in-network qualifying farmers and the probability of having at least one in-network adopter. A more flexible modeling approach proposed by Oster and Thornton (2012), and the one we take, is to use a series of binary variables for each possible number of in-network qualifying farmers.

Social learning can occur either because farmers learn about the benefits of a technology, or how to use a technology. Because LLL is obtained through custom hire, we expect that farmers can learn about its profitability, but not how to better use it. Because these benefits are heterogeneous, we

\footnotetext{
${ }^{13}$ If someone is both a friend and a family member they are only counted once.
} 
expect adopters to confer a variety of information about LLL profitability to their agricultural information networks. Some adopters will have had a good experience with the technology whereas others will have not. Therefore, if learning drives network effects we would expect to see positive network effects from contacts that benefited from the technology and zero or negative network effects from contacts that did not.

An alternative mechanism to social learning is mimicry. Mimicry can arise from a desire to conform, or because the follower assumes the leader has good information and has made a sound decision. We do not believe the latter type of mimicry would occur because adoption was determined in part by a lottery. While LLL may not seem like a technology farmers would adopt in order to conform, it is not out of the question. LLL leaves fields noticeably more level, which is desirable, although our prior is that farmers are more interested in saving water (and therefore money) than they are in having aesthetically pleasing fields. If mimicry drives network effects, we would expect to see them regardless of whether an adopter benefited from using a technology or not.

We consider a farmer to benefit from LLL if he uses at least 14 percent less water during the year after adopting LLL than in the year before. We choose the 14 percent threshold because it is at the lower end of the savings range for which we estimate LLL will be profitable at a price of Rs. 500 per hour, and also near the lower end of the range of water savings found in agronomic trials. We call farmers (both adopters and non-adopters) that reduced water use by at least 14 percent from 2010/11 to 2011/12 'water-savers' and other farmers 'nonsavers'. To account for year-to-year changes in water use unrelated to LLL that could be correlated to unobservable farmer and network characteristics we control for the number of water-saving and nonsaving qualifying farmers in each farmer's network. The econometric model we use to estimate network effects conditional on benefits is: 


$$
\begin{aligned}
\text { WTP }_{i}= & \alpha+\beta_{1} \cdot(\text { adopting watersavers })_{i}+\beta_{2} \cdot(\text { adopting nonsavers })_{i}+\beta_{3} \\
& \cdot(\text { qualifying watersavers })_{i}+\beta_{4} \cdot\left(\text { qualifying nonsavers }{ }_{i}\right)+\beta_{5} \\
& \cdot \text { networksize }_{i}+X_{i}^{\prime} \beta_{4}+\varepsilon_{i} .
\end{aligned}
$$

In (2), adopting watersavers and adopting nonsavers both take on a value of one if farmer $i$ knows at least one water-saving adopter and at least one non-saving adopter. If mimicry drives demand we would expect $\hat{\beta}_{1}=\hat{\beta}_{2}>0$, if learning drives demand we would expect $\hat{\beta}_{1}>0 \geq \hat{\beta}_{2}$, and if there are no network effects we would expect $\hat{\beta}_{1}=\hat{\beta}_{2}=0$. In addition to allowing us to test for social learning, accounting for the different types of information prevents us from muddling two distinct and potentially countervailing effects.

Our full sample includes 478 farmers. Of these, 283 (59.2 percent) won the auction and 144 (30.1 percent of all farmers and 50.8 percent of auction winners) won the lottery. Compliance with lottery outcomes was high. No lottery-losing farmers were able adopt LLL. However, 22 lottery winning farmers (15 percent of lottery winning farmers) were not able to receive LLL, mostly due to heavy and untimely rains that prevented the machinery from operating in some areas. We therefore instrument for an in-network farmer having his fields leveled with an in-network lottery winner, which we know to be exogenous conditional on the number of in-network qualifying farmers. The intent to treat results (Appendix D) are similar to the instrumental variables estimates but slightly attenuated, as expected.

Because LLL lasts for several years, a farmer who had a plot leveled is unlikely to have it leveled again the following year, even at a low price. Therefore, the 39 farmers who had all of their plots leveled after the first auction had no plots to bid on in the second auction and were omitted from analysis. ${ }^{14}$ Another 17 farmers did not attend the second auction, leaving a sample of 422 . Note that farmers

\footnotetext{
${ }^{14}$ Farmers chose the plots they wanted leveled most for the 2011 auction. If these plots were leveled after the auction and lottery, the farmer was left with plots he presumably had less desire to have leveled in 2012. This could downwardly bias estimates of WTP in 2012 for these farmers. However, when we include only farmers who had no plots leveled in 2011 we find the network effects of the same magnitude.
} 
without an in-network qualifying farmer necessarily have a zero probability of having an in-network adopter. Consequently, these farmers contribute little to estimation. As a robustness check we use the subset of 150 farmers who have at least one in-network qualifying farmer-and therefore a non-zero probability of having an in-network adopter-for estimation. The results are nearly identical to those obtained using the full sample and can be found in Appendix E.

\subsection{Network effect results}

Whereas the majority of studies on network effects and technology adoption use a dichotomous adoption variable as the outcome of interest, we use farmer WTP, which allows us to estimate network effects in monetary terms. ${ }^{15}$ Specifically, we regress $W T P_{2}$-revealed after farmers have had one full year to learn about LLL-onto network variables.

Estimating unconditional network effects (equation 1), we find that farmers with at least one innetwork adopting farmer were willing to pay an additional Rs. 98 per hour for LLL service than farmers without an adopting farmer in their network $(p<0.05) .{ }^{16}$ This is 32 percent of mean WTP 2 and equivalent to a 20 percent subsidy of the likely market price. These results can be found in columns 1 and 2 of Table 3. When we estimate conditional network effects (equation 2), we find strong evidence of social learning. Having a water-saving in-network adopter increases $W T P_{2}$ by around Rs. $160(p<0.01)$. This amounts to 52 percent of mean $W T P_{2}$ in the second auction and equals a 32 percent subsidy of the likely market price. A nonsaving in-network adopter has no significant effect on demand, and point estimates are slightly negative and significantly different from the effect of having an in-network water-

\footnotetext{
${ }^{15}$ We are aware of two exceptions: Cai, de Janvry, and Sadoulet (2015) offer farmers insurance policies at different premiums at the household level, and can therefore quantify network effects on demand in monetary terms. Oster and Thornton (2012) use hypothetical bids to estimate peer effects on demand for menstrual cups in Nepal.

${ }^{16}$ Because outcomes may be correlated at the level of the potential network-in this case the village-we attempted estimating (1) and (2) using village-clustered standard errors. The cluster-robust standard errors are generally smaller than un-clustered standard errors, therefore we report the more conservative un-clustered standard errors with our results.
} 
saving farmer $(p<0.05) .{ }^{17}$ These results, found in columns 3 and 4 of Table 3 , indicate that network effects arise because farmers learn about the benefits of LLL. Whereas others have argued that network effects are more likely to drive adoption of hard-to-use technologies where learning about use (rather than about benefits) is important (Oster and Thornton 2012), we find strong evidence of social learning about an easy-to-use technology with visible benefits.

[Table 3 about here]

Using WTP data from an experimental auction instead of observed adoption data allows us to capture shifts in demand that do not push farmers across some price threshold and can help inform what subsidies may be needed to increase second generation adoption (and beyond). To demonstrate this advantage we modify (1) and (2) by using a series of dichotomous outcomes for $W T P_{2} \geq$ Price at various prices (Rs. 250, 350, 500, and 600) as dependent variables. We find that unconditional network effects significantly increase the probability of adoption at lower prices-the effect is 18 percent at Rs. $250(p<0.05)$ and 27 percent at Rs. $350(p<0.05)$ - but not higher ones. We detect conditional network effects at all prices, with larger effects at lower prices -31 percent at Rs. 250 and Rs. $350(p<0.05)$ than higher ones- 22 percent at Rs. 500 and 18 percent at Rs. 600 ( $p<0.05$ for each). Had we not used WTP data to estimate network effects we would not have been able to detect unconditional network effects at the market price, and would have also missed large conditional network effects at the lower end of the demand spectrum. Table 4 contains the estimation results for network effects on adoption at different prices.

[Table 4 about here]

\footnotetext{
${ }^{17}$ In another specification we divide water-saving farmers into 'moderate water savers' (0-50 percent reduction) and 'super water savers' (> 50 percent reduction). We find that a moderate water saver has an effect of Rs. 185 and a super water saver has an effect of Rs 136 . The effects are not statistically distinct $(p=0.65)$, and we therefore interpret this result to mean there is no discernable difference between having a network contact that saves a moderate amount of water versus extreme and amount of water on LLL demand.
} 
Because network effects are conditional on benefits, the common extension strategy of targeting initial adopters that others seek information from, and that are likely to benefit from the technology, seems appropriate for disseminating LLL. In an effort to typify farmers who provide information to others, we regress the number of other farmers claiming an individual as an agricultural information contact onto several farmer characteristics (Table 5). We only find a significant (and negative) impact of being of general caste $(p<0.05)$. Age, sex, education, total landholdings, and wealth do not have a significant effect. Because 87 percent of farmers were claimed as a source of agricultural information by at most one other farmer, we also regress whether or not a farmer is claimed by at least one other sample farmer on these same variables. Doing so, we find a significant and positive effect of education $(p<0.05)$ and again a negative effect of being general caste $(p<0.1)$.

To examine what types of farmers are most likely to benefit from LLL we regress whether or not a farmer saves at least 14 percent of water using LLL onto farm and farmer characteristics (Table 6). We find weak evidence that those who had more land laser leveled, those in a village with a shallower water table, and those who had more uneven land to begin with were more likely to benefit from LLL. We only find strong evidence that farmers who used more water per acre of land before the introduction of LLL were more likely to benefit from the technology $(p<0.01)$, and that farmers in Gorakhpur district were less likely to benefit $(p<0.05)$.

Taken together, these results (weakly) suggest that (1) a good candidate farmer for extension to target is one that uses a lot of water, has uneven plots, and has more land to put under LLL (keeping in mind that landholdings are generally very small), and (2) it is not necessarily more effective to target older and more experienced farmers, farmers with more land, or farmers of high caste. It may, however, be effective to target more educated farmers, as there is some evidence they are more likely to be a source of agricultural information to others. 
Using our data, we can also gain some insight into how farmers learn about LLL through social networks by estimating network effects on different types of exposure: that a farmer discusses LLL with an adopting farmer, that he sees an LLL unit in operation on a farmer's field, and that he observes a laser leveled field. These forms of exposure implicitly capture alternative approaches used by extension services to leverage social networks to disseminate technologies, for example, through increasing farmer-to-farmer interactions, informational interventions (posters, radio programs, seminars, and village meetings), or on-field demonstrations (demonstration plots and farmer field days).

Table 7 contains estimates of network effects on exposure outcomes, obtained using an instrumental variables linear probability model. Unconditional network effects on exposure (equation 1 ) are as follows. We find weak evidence that having an in-network adopter increases the probability of having a conversation about LLL by 18 percent $(p<0.1$, column 1$)$. Having an in-network adopter has a more pronounced effect on the probability that a farmer observes a laser leveled field, increasing it by 28 percent $(p<0.01$, column 3 ). This is unsurprising given the type of network link under consideration. Farmers are likely to talk about farming with those they farm next to, and are also likely to see those farmers' plots. We do not have geospatial data on plot location, and therefore cannot formally test if agricultural information networks are actually geographic networks based on plot location. ${ }^{18}$ However, we do note that having friends and family members who adopted LLL does not increase the probability of observing a leveled plot (results not shown). We find no evidence that having an in-network adopting farmer increases the probability that a farmer would see the leveler in operation (column 5), probably because the leveling process was a very public and visible event that did not require any particular connections to experience.

An alternative explanation for why network effects on demand are conditional on benefits is that only water-saving farmers publicize their use of LLL to others. We test this possibility by estimating

\footnotetext{
${ }^{18}$ In our study site, plots are not often located next to the farmers' homes, which we do have geospatial data on. These homes are generally clustered in the village or sub-village center.
} 
conditional network effects on exposure outcomes, and find no difference between the effect of having a water-saving in-network adopter and a non-saving in-network adopter. If anything, these results show that farmers are more likely to observe the leveled field of an adopting contact that does not save water using the technology (columns 2, 4, and 6).

[Table 7 about here]

\subsection{Placebo test for spurious network effects}

While we are confident that our randomization prevents us from finding network effects erroneously, we perform a placebo test by regressing $W T P_{1}$-revealed before the technology was introduced-on the network variables in equations (1) and (2). If coefficients on network variables are significantly positive (or negative) in these specifications, it would indicate the presence of unobservable variables correlated to both LLL demand and network variables, which could introduce bias. As expected, we find no significant impact of adoption in farmers' networks on WTP for LLL before the technology was introduced in any specification (Table 8). In one specification, the 90 percent confidence interval for the unconditional placebo effect barely includes the point estimate for the actual unconditional network effect. For the other, it does not. Neither 99 percent confidence interval for the conditional placebo effect includes the point estimate for the actual conditional network effect.

[Table 8 about here]

\subsection{Alternative network link types}

For our main analysis we use unidirectional agricultural information links to define networks, but it is possible that farmers learn about agricultural technologies from friends and family. It is also possible that useful information flows both ways through links, in which case using bidirectional links (links that exists if A claims B or B claims A) would be appropriate. To explore these possibilities we estimate network effects under three additional link definitions: (1) unidirectional friends and family links, (2) bidirectional friends and family links, and (3) bidirectional agricultural information links. 
Table 9 contains network effects estimates using these alternate definitions. We find limited evidence that friends and family networks impact demand for LLL. Unconditional network effects are small and not statistically different from zero (column 1). When we estimate conditional network effects we find a positive point estimate for having an in-network water-saving adopter and a negative impact of having a nonsaving adopter. These estimates are statistically distinct from each other $(p<0.05)$, but neither is statistically distinct from zero at conventional levels (column 2). Using bidirectional friends and family links we find similar result as we do using unidirectional links, except that the conditional network effect of having an in-network water-saving adopter is slightly larger and significantly different than zero $(p<0.1)$, but not significantly distinct from the effect of having an in-network nonsaving adopter (columns 3 and 4). When we use bidirectional agricultural information links we find similar results to those we find using unidirectional links, but they are substantially attenuated, and in the case of the unconditional network effect, not statistically significant (columns 5 and 6).

[Table 9 about here]

These results seem reasonable. That network effects on demand are muted when we use friend and family links instead of agricultural information links indicates that agricultural information is gleaned more from specialized relationships focused on agriculture than from general social linkages. ${ }^{19}$ As previously mentioned, discussions about agriculture likely occur when farmers are in their fields. Therefore agricultural information networks could be based on field proximity. Unfortunately, we do not have field-level spatial data that would allow us to test if field proximity drives social learning. Given the specialized nature of agricultural information links, it is unsurprising that using unidirectional links yields stronger network effects than using bidirectional links. This result suggests that farmers form strategic links with those that can provide them with useful information and these links need not be reciprocated.

\footnotetext{
${ }^{19}$ McNiven and Gilligan (2012) also find that specialized agricultural information links to early adopters have a much stronger effect on adoption than other types of links. Conley and Udry (2010), however, find that using a broader definition of a network link does not change their key results.
} 


\subsection{Implications for technology diffusion}

What do these results imply about the role of network effects in technology diffusion? To wrap up this section, we evaluate this question by combining our results on technology benefits with those on network effects to evaluate how social learning is likely to shape technology diffusion if networks are sparse and information is heterogeneous. We find that at a market price of Rs. 500 per hour, our estimated network effects convert a hefty subsidy to early adopters into increased uptake - but not into widespread adoption in the following year.

Suppose we randomly select 20 percent of farming households in a village to receive LLL at a discounted price of Rs. 250 per hour, which is similar to what we did in this study. ${ }^{20}$ Based on the results from the first auction, 60 percent of those offered would adopt LLL at this price. Our network data indicates that the probability of having one (and only one) of these adopting farmers as an agricultural information contact is 0.25 and the probability of having two, three or four is $0.075,0.023$, and 0.0021 , respectively. If half of adopters experience cost savings exceeding the market price, the total probability of having at least one benefiting adopter in one's network would be: $0.25 \times 0.5+0.075 \times 0.5^{2}+0.023 \times 0.5^{3}+0.002 \times 0.5^{4}=0.205$.

Our estimated mean network effect of Rs. 160 would be catalytic for those with $W T P_{1}$ at or above Rs. 340 but below Rs. 500. Being generous and stretching this window to farmers with WTP between Rs. 300 and Rs. 500, we find that 38.9 percent of farmers fall into this range. Thus, network effects should be catalytic for $0.205 \times 38.9=8.0$ percent of farmers. Farmers can also learn about LLL benefits from friends and family, although network effects from this source are smaller than they are from agricultural information contacts (Rs. 60). Doing similar calculations as above for farmers without an adopting agricultural information contact but with an adopting friend or family contact, we find

\footnotetext{
${ }^{20}$ The average number of households in our sample villages was 105 and the average number of household selected for our study was 20 .
} 
friends and family network effects are catalytic for an additional 1.3 percent of farmers. ${ }^{21}$ It is important to keep in mind that these are estimates for initial increases in demand. Increases in subsequent years could be greater because farmers will have learned more about the benefits of LLL from seeing it in its second year, and because more adoption will mean more opportunities to learn about the benefits.

Because LLL in India relies primarily on custom hire service provision as opposed to outright equipment purchases, the demand-side and supply-side of the market will jointly shape diffusion. To a large extent, the same factors that limit the effectiveness of social learning to result in widespread and rapid adoption also constrain the supply-side of the LLL market: heterogeneity in LLL benefits and agronomic conditions generally create uncertainty for service providers. Service providers may have to roam more widely to fully-employ a LLL team, and therefore risk incurring substantial search and transport costs. Nevertheless, as demand slowly increases, service provider risk decreases, and expected profits increase, entry into new areas will steadily become more attractive. In this respect, the rapid uptake of LLL in the western IGP followed by slower, more calculated uptake in EUP would parallel the rapid adoption of hybrid corn in the Midwestern U.S. followed by the steady but slower diffusion in the Southern U.S., where both adoption and conventional marketing models were not as profitable on average (Griliches 1957).

\section{Concluding remarks}

Advancements in agricultural technology that increase productivity and profitability can lead to improvements in the livelihoods and food security of the rural poor. But the dissemination of promising technologies can prove difficult in developing countries, where reaching many small and isolated farmers is prohibitively costly. Extension therefore operates under the assumption that technology

\footnotetext{
${ }^{21}$ While it may be surprising that network effects are only catalytic for 9.3 percent of farmers, there is some additional evidence in the data to support this finding. Of the sample farmers that bid below Rs. 500 in the first auction, only 12.1 percent bid at least Rs. 500 in the second. As stated earlier, there are many reasons WTP could vary between years besides network effects, but that fact that this figure is similar to the 9.3 percent we find in our above calculations bolsters our confidence in that estimate.
} 
disseminated to a small set of farmers will result in many other farmers learning about the benefits of the technology and eventually adopting. The social learning process, however, is nuanced. Where networks are sparse and a technology exhibits heterogeneous benefits, social networks will be limited in their ability to drive widespread and rapid adoption.

In this study we conduct a pair of experimental auctions for a resource conserving technologylaser land leveling (LLL) - coupled with an adoption lottery in eastern Uttar Pradesh, India to achieve two related objectives. First, we compare farmer willingness to pay for LLL to its estimated benefits and likely market price. Second, we estimate the effect of having an early adopter in a farmer's social network on demand for the technology one year after its introduction, conditional on the benefits achieved by the early adopter. We find that the benefits of the technology exceed the likely market price for 43-59 percent of early adopters, and that having an in-network early adopter who benefited from the technology increases demand for LLL by 32 percent of its market price, elevating it into the range of estimated benefits. However, because networks are sparse and benefits are heterogeneous, relatively few farmers receive information that LLL is beneficial. Consequently we estimate in a village where 12 percent of farmers initially adopt a technology at a reduced price, network effects will only catalyze adoption among an additional 9 percent of farmers.

In the framework of Griliches (1957), EUP is a region of lagging adoption compared to more fertile areas under greater water scarcity to the west. In those areas, the large benefits of LLL are readily apparent. In EUP - and, indeed, throughout most of South Asia - average profitability of LLL is lower and more heterogeneous, which makes learning about benefits all the more important. Yet learning can be difficult when there are few initial adopters and production conditions vary widely. While LLL service providers have ventured cautiously into EUP given the uncertainty about LLL demand and potentially high costs of provision, a private market for LLL services has steadily emerged in the region in recent years. As of Fall 2014, there were 42 LLL units operating in the area and nearly 400 farmers on record as 
having received LLL in 2014. ${ }^{22}$ Moreover, anecdotal reports suggest that this market has emerged in clusters around the areas included in our study, which exposed farmers to the technology. While we do not have data to test these claims empirically, we nevertheless find it encouraging that enough farmers in the greater study area find that LLL is beneficial at market prices to incentivize the slow but steady entry of private service providers into the area. ${ }^{23}$

Network effects can be powerful, but their impact on adoption will be limited by the amount and content of information they convey. Policies aimed at promoting connections between farmers and improving information flow can therefore increase the efficacy of social networks to disseminate technologies. Examples of such policies include forming farmer self-help groups (Vasilaky 2012) or providing incentives for farmers to inform their peers about new technologies and encouraging them to adopt (BenYishay and Mobarak 2013). In promoting social networks as a platform for technology diffusion, however, we must be cognizant of how underlying heterogeneity in production conditions and prospective benefits of new technologies interact with these social learning processes.

\footnotetext{
22 The current market price is around Rs. 700-900, reflecting the 35 percent increase in the price of diesel since 2012, which affects both farmer benefits and producer costs. As far as we know, the newly-established service providers continue to follow the fixed per hour pricing model in EUP as opposed to experimenting with novel pricing models.

${ }^{23}$ Personal communication with Anurag Ajay and R.K. Malik, December 2 and 8, 2014.
} 


\section{Acknowledgements}

This research was funded by the U.S. Agency for International Development and the Bill and Melinda Gates Foundation through the Cereal Systems Initiative for South Asia, and by the International Food Policy Research Institute through a Strategic Innovation Fund grant. We thank Anil Bhargava, Sanjay Prasad, Hemant Pullabhotla, and Vartika Singh for excellent research assistance, and R.K. Malik, Joginder Singh, Ajay Kumar Pundir, Raman Sharma, Shahnawaz Rasool Dar, Gautam Singh, and Satyendra Kumar Singh for field assistance. We are grateful for useful comments and advice from Lori Beaman, Jere Berhman, Alain de Janvry, Dan Gilligan, M.L. Jat, Annemie Maertens, Shalani Roy, Sharon Shewmake, Will Thompson, Wally Thurman, Tom Walker, Xiaoyong Zheng, and participants at various workshops, conferences, and seminars where earlier versions of this paper were presented. We especially thank Scott McNiven, whose conversations with the first author about farmer networks over several years were especially helpful and enjoyable. Scott recently left us far too soon, and we miss him dearly. Any and all errors are the sole responsibility of the authors. 


\section{References}

Alkire, S., and M.E. Santos. 2010. "Acute Multidimensional Poverty: A New Index for Developing Countries." SSRN eLibrary.

Anderson, J., and G. Feder. 2007. "Agricultural Extension". In R. Evenson, and P. Pingali, ed. Handbook of Agricultural Economics. pp. 2343-2378.

Babcock, P., and J. Hartman. 2010. "Networks and Workouts: Treatment Size and Status Specific Peer Effects in a Randomized Field Experiment." NBER Working Papers.

Bandiera, O., and I. Rasul. 2006. "Social Networks and Technology Adoption in Northern Mozambique." The Economic Journal 116(514):869-902.

Becker, G.M., M.H. DeGroot, and J. Marschak. 1964. "Measuring Utility by a Single-Response Sequential Method." Behavioral Science 9(3):226-232.

BenYishay, A., and A.M. Mobarak. 2013. "Communicating with Farmers through Social Networks." Yalue University.

Besley, T., and A. Case. 1994. "Diffusion as a Learning Process: Evidence from Hyv Cotton." Princeton University.

Birner, R., K. Davis, J. Pender, E. Nkonya, P. Anandajayasekeram, J. Ekboir, A. Mbabu, D.J. Spielman, D. Horna, and S. Benin. 2009. "From Best Practice to Best Fit: A Framework for Designing and Analyzing Pluralistic Agricultural Advisory Services Worldwide." Journal of Agricultural Education and Extension 15(4):341-355.

Cai, J., A. de Janvry, and E. Sadoulet. 2015. "Social Networks and the Decision to Insure." American Economic Journal: Applied Economics 7(2):81-108.

Conley, T., and C. Udry. 2010. "Learning About a New Technology: Pineapple in Ghana." The American Economic Review 100(1):35-69.

Feder, G. 1980. "Farm Size, Risk Aversion and the Adoption of New Technology under Uncertainty." Oxford Economic Papers:263-283.

Foster, A., and M. Rosenzweig. 1995. "Learning by Doing and Learning from Others: Human Capital and Technical Change in Agriculture." Journal of Political Economy 103(6):1176-1209.

Griliches, Z. 1957. "Hybrid Corn: An Exploration in the Economics of Technological Change." Econometrica:501-522.

Jackson, M.O., and A. Wolinsky. 1996. "A Strategic Model of Social and Economic Networks." Journal of economic theory 71(1):44-74.

Jat, M. 2012. "Laser Land Leveling in India: A Success." Paper presented at Lessons Learned from Postharvest and Mechanization Projects, and Ways Forward. Los Banos, Philippines, May 22-24.

Jat, M., P. Chandna, R. Gupta, S. Sharma, and M. Gill. 2006. "Laser Land Leveling: A Precursor Technology for Resource Conservation." Rice-Wheat Consortium Technical Bulletin Series 7.

Jat, M., R. Gupta, P. Ramasundaram, M. Gathala, H. Sidhu, S. Singh, R.G. Singh, Y. Saharawat, V. Kumar, and P. Chandna. 2009. "Laser-Assisted Precision Land Leveling: A Potential Technology for Resource Conservation in Irrigated Intensive Production Systems of the Indo-Gangetic Plains". In J.K. Ladha,Yadvinder-Singh,O. Erenstein, and B. Hardy, ed. Integrated Crop and Resource Management in the Rice-Wheat System of South Asia. Los Banos, Philippines: International Rice Research Institute, pp. 223.

Liu, E.M. 2013. "Time to Change What to Sow: Risk Preferences and Technology Adoption Decisions of Cotton Farmers in China." Review of Economics and Statistics 95(4):1386-1403.

Lybbert, T.J., N. Magnan, A.K. Bhargava, K. Gulati, and D.J. Spielman. 2014. "Targeting Technology to Reduce Poverty and Counserve Resources: Experimental Delivery of Laser Land Leveling to Farmers in Uttar Pradesh, India." University of California, Davis. 
Maertens, A. 2013. "Who Cares What Others Think (or Do)? Social Learning, Social Pressures, and Cotton Farming in India." University of Pittsburgh.

Maertens, A., and C.B. Barrett. 2012. "Measuring Social Network Effects on Agricultural Technology Adoption." American Journal of Agricultural Economics 95(2):353-359.

Manski, C. 1993. "Identification of Endogenous Social Effects: The Reflection Problem." The Review of Economic Studies 60(3):531-542.

McNiven, S., and D. Gilligan. 2012. "Networks and Constraints on Teh Diffusion of a Biofortified Agricultural Technology: Evidence from a Partial Population Experiment." University of California, Davis.

Munshi, K. 2004. "Social Learning in a Heterogeneous Population: Technology Diffusion in the Indian Green Revolution." Journal of Development Economics 73(1):185-213.

Munshi, K., and J. Myaux. 2006. "Social Norms and the Fertility Transition." Journal of Development Economics 80(1):1-38.

National Remote Sensing Centre. 2014. Water Resources Information System of India. http://indiawris.nrsc.gov.in/wrpinfo/?title=Ground water resources.

Oster, E., and R. Thornton. 2012. "Determinants of Technology Adoption:Peer Effects in Menstrual Cup Take-Up." Journal of the European Economic Association 10(6):1263-1293.

Suri, T. 2011. "Selection and Comparative Advantage in Technology Adoption." Econometrica 79(1):159209.

Vasilaky, K. 2012. "Female Social Networks and Farmer Training: Can Randomized Information Exchange Improve Outcomes?" American Journal of Agricultural Economics 95(2):376-383. 
Figures and Tables

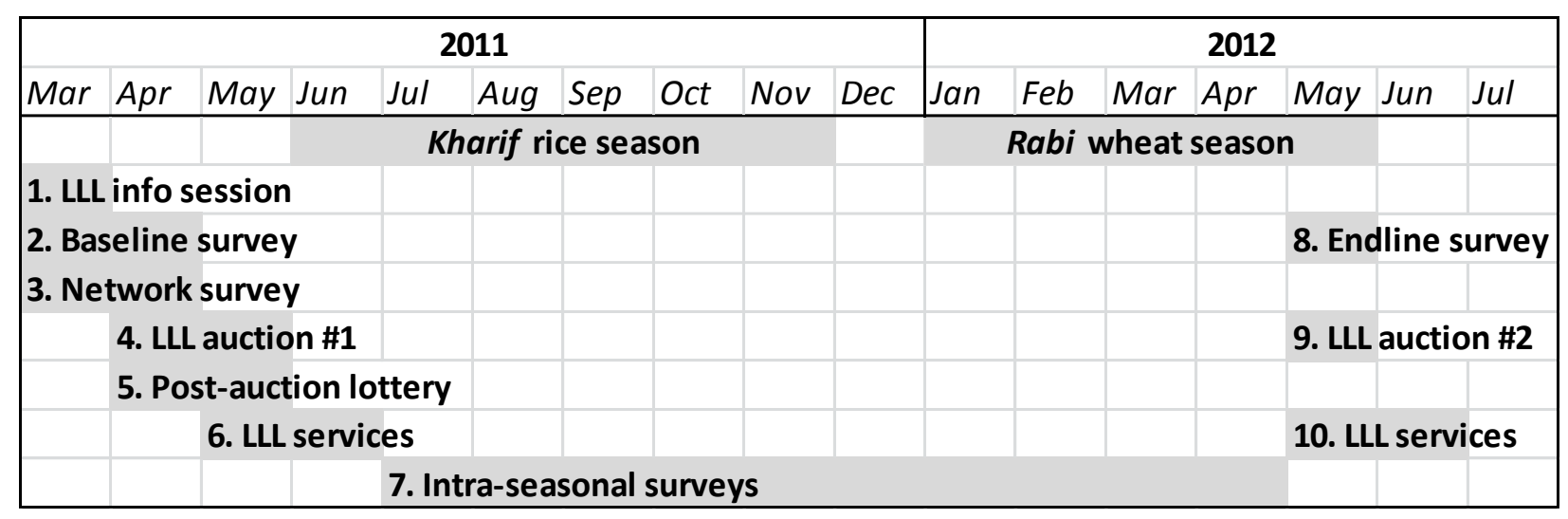

Figure 1. Project timeline

Figure 2. Frequency of bids for LLL custom hire in 2011 and 2012 auctions

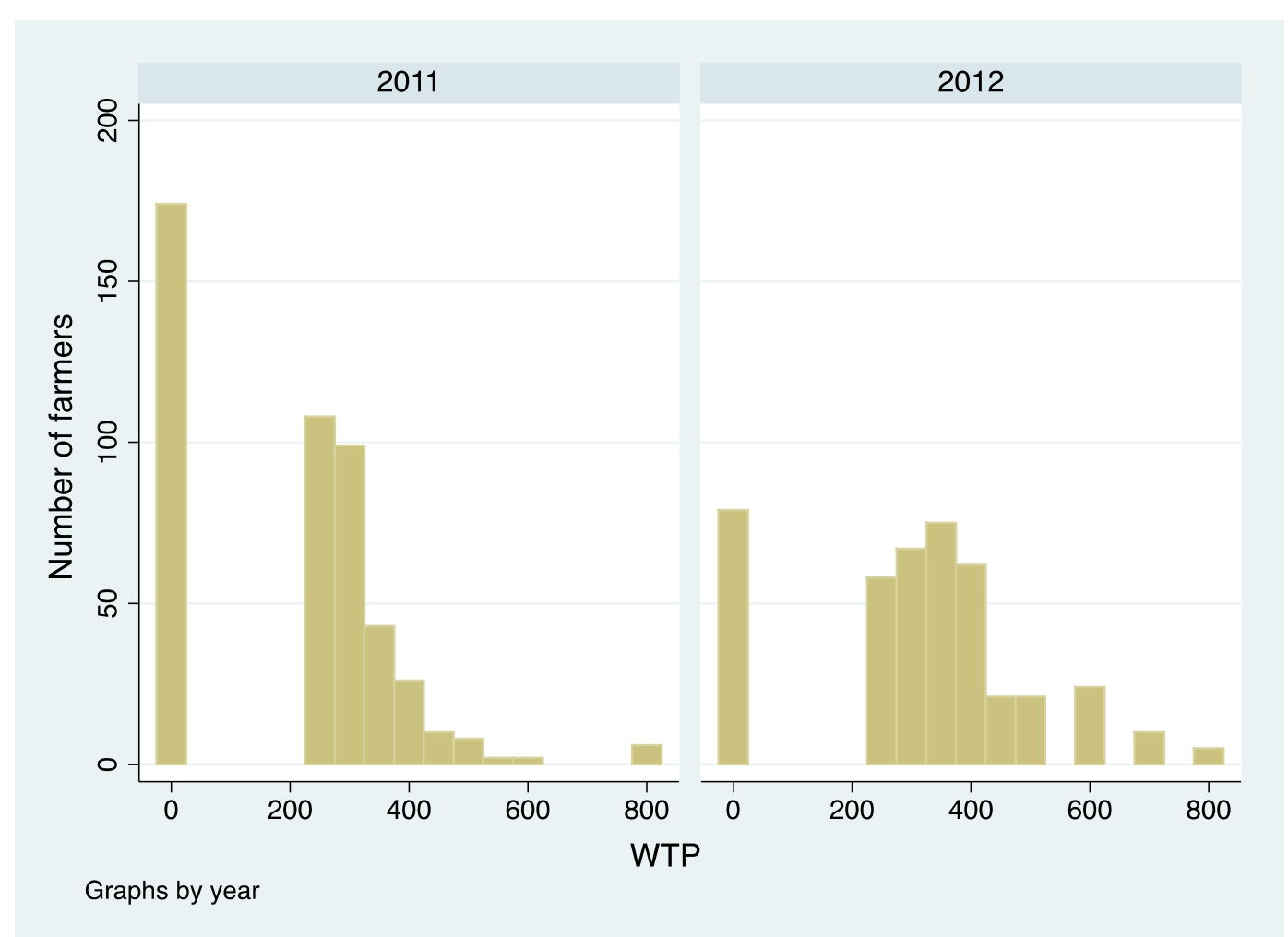



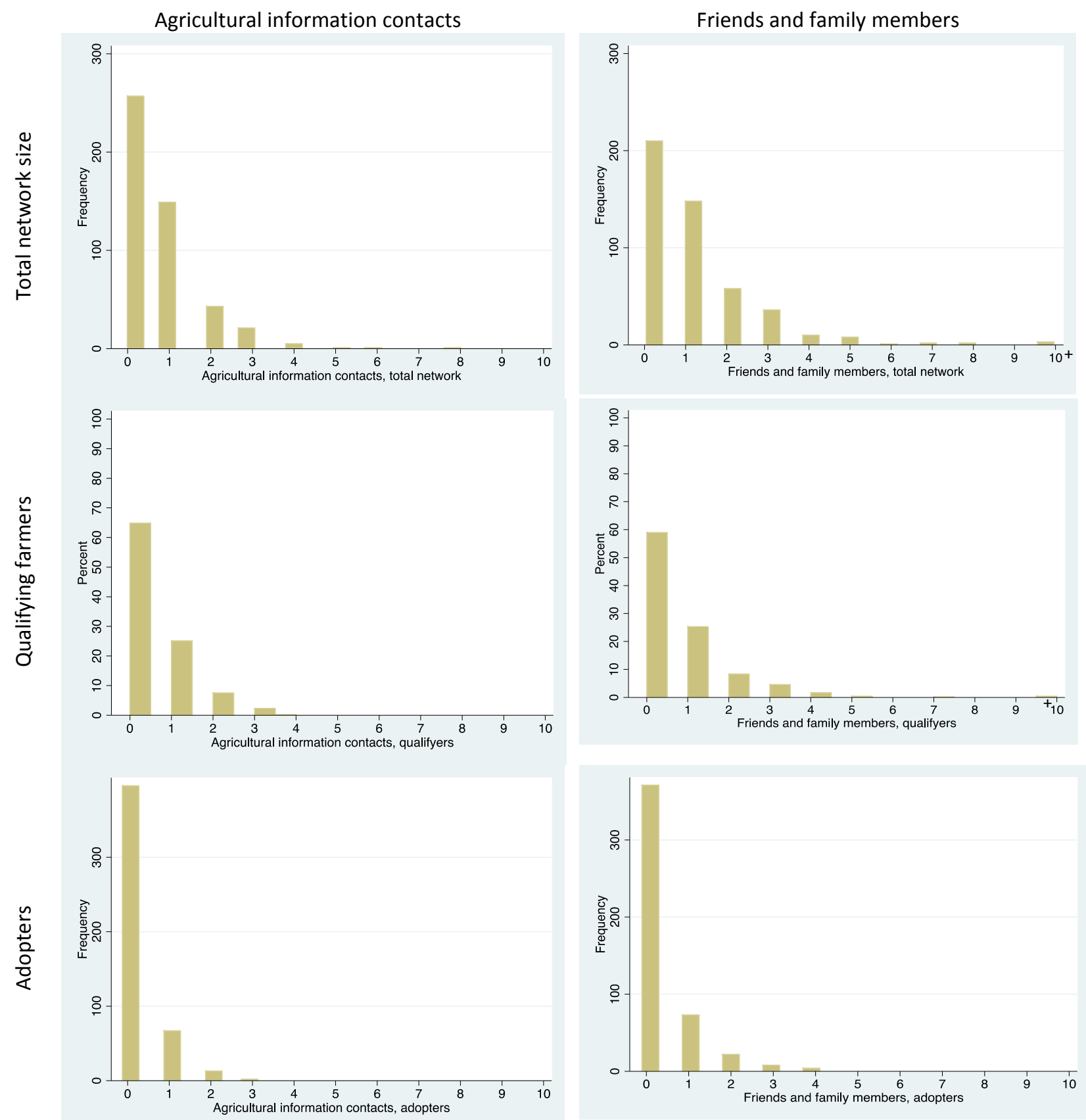

Figure 3. All farmers (top row), Qualifying Farmers (middle row), and adopters (bottom row) among agricultural information contacts (left) and friends and family members (right) 
Table 1-Demographic and WTP (2011 auction) differences between auction winners and losers (left two columns) and lottery winners and losers (right two columns)

\begin{tabular}{|c|c|c|c|c|c|c|}
\hline \multirow[t]{2}{*}{ Variable } & \multicolumn{3}{|c|}{ Auction } & \multicolumn{3}{|c|}{ Lottery (qualifying farmers only) } \\
\hline & $\begin{array}{l}\text { Auction } \\
\text { Losers }\end{array}$ & $\begin{array}{c}\text { Qualifying } \\
\text { farmers }\end{array}$ & $\begin{array}{l}\text { P-value for } \\
\text { difference }\end{array}$ & Losers & Winners & $\begin{array}{l}\text { P-value for } \\
\text { difference }\end{array}$ \\
\hline Age (years) & $\begin{array}{l}47.90 \\
(1.10)\end{array}$ & $\begin{array}{l}48.83 \\
(0.94)\end{array}$ & 0.52 & $\begin{array}{l}48.81 \\
(1.36)\end{array}$ & $\begin{array}{l}48.85 \\
(1.36)\end{array}$ & 0.99 \\
\hline $\begin{array}{l}\text { Education } \\
\text { (years) }\end{array}$ & $\begin{array}{c}5.69 \\
(0.38)\end{array}$ & $\begin{array}{c}6.94 \\
(0.33)\end{array}$ & 0.01 & $\begin{array}{c}6.88 \\
(0.47)\end{array}$ & $\begin{array}{c}7.00 \\
(0.47)\end{array}$ & 0.86 \\
\hline $\begin{array}{l}\text { Total land } \\
\text { (acres) }\end{array}$ & $\begin{array}{c}1.40 \\
(0.27)\end{array}$ & $\begin{array}{c}2.31 \\
(0.23)\end{array}$ & 0.01 & $\begin{array}{c}2.26 \\
(0.35)\end{array}$ & $\begin{array}{c}2.35 \\
(0.35)\end{array}$ & 0.85 \\
\hline Wealth index & $\begin{array}{l}-0.18 \\
(0.05)\end{array}$ & $\begin{array}{c}0.09 \\
(0.06)\end{array}$ & 0.00 & $\begin{array}{c}0.06 \\
(0.08)\end{array}$ & $\begin{array}{c}0.11 \\
(0.08)\end{array}$ & 0.67 \\
\hline $\begin{array}{l}\text { WTP (2011 } \\
\text { auction) }\end{array}$ & $\begin{array}{l}36.15 \\
(6.50)\end{array}$ & $\begin{array}{c}320.49 \\
(6.48)\end{array}$ & 0.00 & $\begin{array}{c}324.82 \\
(9.53)\end{array}$ & $\begin{array}{c}316.32 \\
(9.53)\end{array}$ & 0.51 \\
\hline Observations & 195 & 283 & & 139 & 144 & \\
\hline
\end{tabular}

Notes: Standard errors in parentheses. Only farmers with at least one in-network qualifying farmer are included. Wealth index consists of house condition; ration card possession; landholdings; and ownership of cell phones, vehicles, TVs, satellite dish, and livestock.

Table 2-Laser Land Leveling benefits under different depreciation and discounting

\begin{tabular}{lcccc}
\hline \hline & \multicolumn{3}{c}{ Scenarios } \\
& $\begin{array}{c}\text { Optimistic (no depreciation } \\
\text { over four years) }\end{array}$ & \multicolumn{2}{c}{$\begin{array}{c}\text { Conservative (linear } \\
\text { depreciation over four years) }\end{array}$} \\
\hline & $\begin{array}{c}\text { No } \\
\text { discounting }\end{array}$ & $\begin{array}{c}20 \% \text { discount } \\
\text { rate }\end{array}$ & $\begin{array}{c}\text { No } \\
\text { discounting }\end{array}$ & $\begin{array}{c}20 \% \text { discount } \\
\text { rate }\end{array}$ \\
\hline Single year benefits (Rs./hour) & 198 & 187 & 198 & 187 \\
$\begin{array}{l}\text { Four-year benefit stream (Rs./hour) } \\
\text { \% water savings for benefit stream }>\end{array}$ & 792 & 653 & 495 & 428 \\
$\begin{array}{l}\text { Rs. 500 per hour } \\
\text { \% of adopting farmers benefiting by }>\end{array}$ & $14 \%$ & $18 \%$ & $26 \%$ & $31 \%$ \\
Rs. 500 per hour & $59 \%$ & $56 \%$ & $53 \%$ & $43 \%$ \\
\hline
\end{tabular}

Note: For discounting, we consider two distinct points in time to receive benefits, in the middle of the rice season (approximately 4 months after leveling) and in the middle of the wheat season (approximately 9 months after). We split water savings 60 to 40 wheat to rice, reflecting the split we find in the data. 
Table 3-Network effects on demand for LLL

\begin{tabular}{|c|c|c|c|c|}
\hline Dependent variable: WTP 2012 & (1) & $(2)$ & (3) & $(4)$ \\
\hline \multirow[t]{2}{*}{ At least one adopter in network } & $98.29 * *$ & $97.97 * *$ & & \\
\hline & $(39.90)$ & $(38.67)$ & & \\
\hline \multirow{3}{*}{$\begin{array}{l}\text { At least one adopter in network } \\
\text { (water savers) }\end{array}$} & & & $156.50 * * *$ & $164.93 * * *$ \\
\hline & & & (51.09) & $(49.14)$ \\
\hline & & & {$[0.03]$} & {$[0.02]$} \\
\hline \multirow{2}{*}{$\begin{array}{l}\text { At least one adopter in network } \\
\text { (nonsavers) }\end{array}$} & & & 0.45 & -16.41 \\
\hline & & & $(47.71)$ & $(52.18)$ \\
\hline \multirow[t]{2}{*}{ One qualifying farmer in network } & 23.77 & 13.27 & & \\
\hline & (31.24) & $(30.26)$ & & \\
\hline \multirow[t]{2}{*}{ Two qualifying farmers in network } & -17.18 & -60.85 & & \\
\hline & $(60.22)$ & $(58.91)$ & & \\
\hline \multirow[t]{2}{*}{ Three qualifying farmers in network } & -10.28 & -44.14 & & \\
\hline & $(91.70)$ & (90.16) & & \\
\hline \multirow[t]{2}{*}{ Four qualifying farmers in network } & 296.17 & 212.75 & & \\
\hline & $(234.13)$ & $(227.00)$ & & \\
\hline \multirow{2}{*}{$\begin{array}{l}\text { One qualifying farmer in network } \\
\text { (water savers) }\end{array}$} & & & -18.83 & -36.28 \\
\hline & & & $(36.46)$ & $(35.21)$ \\
\hline \multirow{2}{*}{$\begin{array}{l}\text { Two qualifying farmers in network } \\
\text { (water savers) }\end{array}$} & & & $-134.14^{*}$ & $-183.89 * *$ \\
\hline & & & $(77.31)$ & (76.01) \\
\hline \multirow{2}{*}{$\begin{array}{l}\text { Three qualifying farmers in network } \\
\text { (water-savers) }\end{array}$} & & & -122.89 & -205.32 \\
\hline & & & $(217.88)$ & $(210.71)$ \\
\hline \multirow{2}{*}{$\begin{array}{l}\text { One qualifying farmer in network } \\
\text { (nonsavers) }\end{array}$} & & & $62.95^{*}$ & 49.12 \\
\hline & & & (36.14) & $(34.98)$ \\
\hline \multirow{2}{*}{$\begin{array}{l}\text { Two qualifying farmers in network } \\
\text { (water-savers) }\end{array}$} & & & 28.77 & 25.99 \\
\hline & & & $(82.34)$ & (79.61) \\
\hline \multirow{2}{*}{$\begin{array}{l}\text { Three qualifying farmers in network } \\
\text { (water-savers) }\end{array}$} & & & 18.57 & 83.10 \\
\hline & & & $(195.61)$ & $(189.47)$ \\
\hline \multirow{2}{*}{$\begin{array}{l}\text { Four qualifying farmers in network } \\
\text { (water-savers) }\end{array}$} & & & 342.90 & 279.50 \\
\hline & & & $(237.56)$ & $(230.20)$ \\
\hline \multirow[t]{2}{*}{ Total network size } & -11.37 & -9.81 & -4.87 & -3.79 \\
\hline & (18.16) & (17.64) & $(18.70)$ & (18.15) \\
\hline \multirow[t]{2}{*}{ Age (10 years) } & & -2.67 & & -1.85 \\
\hline & & (5.98) & & $(5.85)$ \\
\hline \multirow[t]{2}{*}{ Education (years) } & & 0.50 & & 0.90 \\
\hline & & $(1.78)$ & & $(1.76)$ \\
\hline \multirow[t]{2}{*}{ Wealth index } & & 15.11 & & 15.07 \\
\hline & & (10.49) & & $(10.38)$ \\
\hline \multirow[t]{2}{*}{ WTP 2011 (Rs. 100/hour) } & & $0.26 * * *$ & & $0.26 * * *$ \\
\hline & & $(0.05)$ & & $(0.05)$ \\
\hline \multirow[t]{2}{*}{ Constant } & $296.47 * * *$ & $260.04 * * *$ & $295.58 * * *$ & $254.64 * * *$ \\
\hline & (11.60) & (36.10) & (11.31) & (35.63) \\
\hline Observations & 422 & 422 & 422 & 422 \\
\hline
\end{tabular}

Notes: Water-saving denotes using 14 percent less water in 2011-2012 than in 2010-2011. IV model with lottery winning farmers instrumenting for farmers receiving leveling. Standard errors in parenthesis; *** $\mathrm{p}<0.01, * * \mathrm{p}<0.05, * \mathrm{p}<0.1$. P-value for difference between effect of water-saver and nonsaving network contacts is in brackets. Omitted indicator variable is for no in-network qualifying farmers. 
Table 4-Network effects on demand at various prices

\begin{tabular}{|c|c|c|c|c|c|c|c|c|}
\hline Dependent variable: WTP 2012 & $\begin{array}{c}(1) \\
\text { Rs.250 }\end{array}$ & $\begin{array}{c}(2) \\
\text { Rs.350 }\end{array}$ & $\begin{array}{c}(3) \\
\text { Rs.500 }\end{array}$ & $\begin{array}{c}(4) \\
\text { Rs. } 600\end{array}$ & $\begin{array}{c}(5) \\
\text { Rs. } 250\end{array}$ & $\begin{array}{c}(6) \\
\text { Rs. } 350\end{array}$ & $\begin{array}{c}(7) \\
\text { Rs.500 }\end{array}$ & $\begin{array}{c}(8) \\
\text { Rs. } 600\end{array}$ \\
\hline At least one adopter in network & $\begin{array}{l}0.18 * * \\
(0.08)\end{array}$ & $\begin{array}{l}0.27^{* *} \\
(0.11)\end{array}$ & $\begin{array}{c}0.11 \\
(0.07)\end{array}$ & $\begin{array}{c}0.07 \\
(0.06)\end{array}$ & & & & \\
\hline $\begin{array}{l}\text { At least one adopter in network } \\
\text { (water savers) }\end{array}$ & & & & & $\begin{array}{c}0.31 * * * \\
(0.11) \\
{[0.394]}\end{array}$ & $\begin{array}{c}0.31 * * \\
(0.14) \\
{[0.528]}\end{array}$ & $\begin{array}{c}0.22 * * \\
(0.10) \\
{[0.071]}\end{array}$ & $\begin{array}{c}0.18 * * \\
(0.08) \\
{[0.047]}\end{array}$ \\
\hline $\begin{array}{l}\text { At least one adopter in network } \\
\text { (nonsavers) }\end{array}$ & & & & & $\begin{array}{l}-0.04 \\
(0.11)\end{array}$ & $\begin{array}{c}0.14 \\
(0.15)\end{array}$ & $\begin{array}{l}-0.06 \\
(0.10)\end{array}$ & $\begin{array}{l}-0.08 \\
(0.08)\end{array}$ \\
\hline $\begin{array}{l}\text { Controls for number of qualifying } \\
\text { farmers in network }\end{array}$ & Yes & Yes & Yes & Yes & & & & \\
\hline $\begin{array}{l}\text { Controls for number of qualifying } \\
\text { water saving farmers in network }\end{array}$ & & & & & Yes & Yes & Yes & Yes \\
\hline $\begin{array}{l}\text { Controls for number of qualifying } \\
\text { nonsaving farmers in network }\end{array}$ & & & & & Yes & Yes & Yes & Yes \\
\hline Total network size & $\begin{array}{c}0.00 \\
(0.04)\end{array}$ & $\begin{array}{l}-0.06 \\
(0.05)\end{array}$ & $\begin{array}{l}-0.01 \\
(0.03)\end{array}$ & $\begin{array}{c}0.00 \\
(0.03)\end{array}$ & $\begin{array}{c}0.01 \\
(0.04)\end{array}$ & $\begin{array}{l}-0.04 \\
(0.05)\end{array}$ & $\begin{array}{c}0.00 \\
(0.04)\end{array}$ & $\begin{array}{c}0.01 \\
(0.03)\end{array}$ \\
\hline Age (10 years) & $\begin{array}{l}-0.00 \\
(0.01)\end{array}$ & $\begin{array}{l}-0.01 \\
(0.02)\end{array}$ & $\begin{array}{l}-0.01 \\
(0.01)\end{array}$ & $\begin{array}{c}0.00 \\
(0.01)\end{array}$ & $\begin{array}{l}-0.00 \\
(0.01)\end{array}$ & $\begin{array}{l}-0.01 \\
(0.02)\end{array}$ & $\begin{array}{l}-0.00 \\
(0.01)\end{array}$ & $\begin{array}{c}0.00 \\
(0.01)\end{array}$ \\
\hline Education (years) & $\begin{array}{c}0.00 \\
(0.00)\end{array}$ & $\begin{array}{c}0.00 \\
(0.00)\end{array}$ & $\begin{array}{l}-0.00 \\
(0.00)\end{array}$ & $\begin{array}{l}-0.00 \\
(0.00)\end{array}$ & $\begin{array}{c}0.00 \\
(0.00)\end{array}$ & $\begin{array}{c}0.00 \\
(0.00)\end{array}$ & $\begin{array}{l}-0.00 \\
(0.00)\end{array}$ & $\begin{array}{l}-0.00 \\
(0.00)\end{array}$ \\
\hline Wealth index & $\begin{array}{c}0.05^{* *} \\
(0.02)\end{array}$ & $\begin{array}{c}0.01 \\
(0.03)\end{array}$ & $\begin{array}{c}0.00 \\
(0.02)\end{array}$ & $\begin{array}{c}0.00 \\
(0.02)\end{array}$ & $\begin{array}{c}0.06 * * * \\
(0.02)\end{array}$ & $\begin{array}{c}0.01 \\
(0.03)\end{array}$ & $\begin{array}{l}-0.00 \\
(0.02)\end{array}$ & $\begin{array}{l}-0.00 \\
(0.02)\end{array}$ \\
\hline WTP 2011 (Rs. 100/hour) & $\begin{array}{c}0.04 * * * \\
(0.01)\end{array}$ & $\begin{array}{c}0.06 * * * \\
(0.01)\end{array}$ & $\begin{array}{c}0.04^{* * *} \\
(0.01)\end{array}$ & $\begin{array}{c}0.03^{* * *} \\
(0.01)\end{array}$ & $\begin{array}{c}0.04^{* * *} \\
(0.01)\end{array}$ & $\begin{array}{c}0.06 * * * \\
(0.01)\end{array}$ & $\begin{array}{c}0.04 * * * \\
(0.01)\end{array}$ & $\begin{array}{c}0.03 * * * \\
(0.01)\end{array}$ \\
\hline Constant & $\begin{array}{c}0.74 * * * \\
(0.08)\end{array}$ & $\begin{array}{c}0.41^{* * *} \\
(0.10)\end{array}$ & $\begin{array}{c}0.10 \\
(0.07)\end{array}$ & $\begin{array}{c}0.02 \\
(0.06)\end{array}$ & $\begin{array}{c}0.73^{* * *} \\
(0.08)\end{array}$ & $\begin{array}{c}0.42 * * * \\
(0.10)\end{array}$ & $\begin{array}{c}0.09 \\
(0.07)\end{array}$ & $\begin{array}{c}0.01 \\
(0.06)\end{array}$ \\
\hline Observations & 422 & 422 & 422 & 422 & 422 & 422 & 422 & 422 \\
\hline
\end{tabular}

Notes: Water-saving denotes using 14 percent less water in 2011-2012 than in 2010-2011. IV model with lottery winning farmers instrumenting for farmers receiving leveling. Standard errors in parenthesis; $* * * p<0.01, * * p<0.05, * p<0.1$. P-value for difference between effect of water-saver and nonsaving network contacts is in brackets. Omitted indicator variable is for no in-network qualifying farmers. 
Table 5-Associations between farmer characteristics and network connectivity

\begin{tabular}{lcc}
\hline $\begin{array}{l}\text { Dependent variable: Other farmers } \\
\text { claiming as an ag info contact }\end{array}$ & $\begin{array}{c}(1) \\
\text { \# of contacts }\end{array}$ & $\begin{array}{c}(2) \\
\geq 1 \text { contact }\end{array}$ \\
\hline Farmer is male & 0.44 & 0.07 \\
& $(0.43)$ & $(0.15)$ \\
Age (10 years) & -0.02 & 0.00 \\
& $(0.10)$ & $(0.03)$ \\
Education (years) & 0.03 & $0.02^{* *}$ \\
& $(0.03)$ & $(0.01)$ \\
Wealth index & 0.23 & 0.02 \\
& $(0.15)$ & $0.05)$ \\
Landholdings (100 acres) & 0.04 & -0.83 \\
& $(4.74)$ & $(1.76)$ \\
Farmer is general caste & $-0.68 * *$ & $-0.19 *$ \\
& $(0.31)$ & $0.10)$ \\
Constant & 0.51 & \\
& $(0.60)$ & \\
Observations & 118 & 118 \\
R-squared & 0.07 & 0.045 \\
\hline Notes: Model $(1)$ estimated using OLS, model (2) estimated using logit \\
with marginal effects and pseudo R2 reported. Standard errors in \\
parentheses; ${ }^{* * *}$ p $<0.01,{ }^{* *} p<0.05,{ }^{*} p<0.1$. &
\end{tabular}


Table 6- Associations between farm and farmer characteristics and probability of benefiting from LLL

\begin{tabular}{|c|c|c|c|c|}
\hline $\begin{array}{l}\text { Dependent variable: Farmer saved at } \\
\text { least } 14 \% \text { water using LLL }\end{array}$ & (1) & (2) & (3) & (4) \\
\hline Area under LLL & $\begin{array}{c}0.06 \\
(0.04)\end{array}$ & $\begin{array}{l}0.10^{*} \\
(0.05)\end{array}$ & $\begin{array}{c}0.07 \\
(0.04)\end{array}$ & $\begin{array}{c}0.11^{* *} \\
(0.05)\end{array}$ \\
\hline Primarily heavy soil & $\begin{array}{c}0.06 \\
(0.08)\end{array}$ & $\begin{array}{c}0.03 \\
(0.09)\end{array}$ & $\begin{array}{c}0.07 \\
(0.08)\end{array}$ & $\begin{array}{c}0.04 \\
(0.08)\end{array}$ \\
\hline Primarily upland & $\begin{array}{c}0.03 \\
(0.09)\end{array}$ & $\begin{array}{c}0.05 \\
(0.09)\end{array}$ & $\begin{array}{c}0.02 \\
(0.09)\end{array}$ & $\begin{array}{c}0.05 \\
(0.09)\end{array}$ \\
\hline Water table depth $(10 \mathrm{~m})$ in village & $\begin{array}{l}-0.09 * \\
(0.05)\end{array}$ & $\begin{array}{l}-0.08^{*} \\
(0.05)\end{array}$ & $\begin{array}{l}-0.06 \\
(0.05)\end{array}$ & $\begin{array}{l}-0.05 \\
(0.05)\end{array}$ \\
\hline Average plot levelness ( $1-5,5$ most level) & $\begin{array}{l}-0.05 \\
(0.04)\end{array}$ & $\begin{array}{l}-0.06 \\
(0.04)\end{array}$ & $\begin{array}{l}-0.07 \\
(0.04)\end{array}$ & $\begin{array}{c}-0.08^{*} \\
(0.05)\end{array}$ \\
\hline Log water use per acre (100,000 gallons) & $\begin{array}{c}0.30^{* * *} \\
(0.05)\end{array}$ & $\begin{array}{c}0.30 * * * \\
(0.05)\end{array}$ & $\begin{array}{c}0.30 * * * \\
(0.05)\end{array}$ & $\begin{array}{c}0.29 * * * \\
(0.05)\end{array}$ \\
\hline Age (10 years) & & $\begin{array}{l}-0.03 \\
(0.03)\end{array}$ & & $\begin{array}{l}-0.04 \\
(0.03)\end{array}$ \\
\hline Education (years) & & $\begin{array}{l}-0.01 \\
(0.01)\end{array}$ & & $\begin{array}{l}-0.00 \\
(0.01)\end{array}$ \\
\hline Wealth index & & $\begin{array}{c}0.03 \\
(0.05)\end{array}$ & & $\begin{array}{c}0.05 \\
(0.05)\end{array}$ \\
\hline Landholdings (100 acres) & & $\begin{array}{l}-1.60 \\
(1.90)\end{array}$ & & $\begin{array}{l}-2.42 \\
(1.91)\end{array}$ \\
\hline Gorakhpur District & & & $\begin{array}{l}-0.16^{*} \\
(0.10)\end{array}$ & $\begin{array}{l}-0.17^{*} \\
(0.10)\end{array}$ \\
\hline Deoria District & & & $\begin{array}{l}-0.02 \\
(0.10)\end{array}$ & $\begin{array}{c}0.04 \\
(0.11)\end{array}$ \\
\hline Observations & 110 & 110 & 110 & 110 \\
\hline Pseudo R2 & 0.240 & 0.259 & 0.260 & 0.282 \\
\hline
\end{tabular}


Table 7-Network effects on mode of exposure to LLL

\begin{tabular}{|c|c|c|c|c|c|c|}
\hline \multirow[t]{2}{*}{ Exposure to LLL through... } & \multicolumn{2}{|c|}{$\begin{array}{l}\text {... conversation with adopting } \\
\text { farmer about LLL }\end{array}$} & \multicolumn{2}{|c|}{$\begin{array}{l}\text {...seeing LLL unit } \\
\text { operate }\end{array}$} & \multicolumn{2}{|c|}{$\begin{array}{l}\text {...observing field of } \\
\text { adopting farmer }\end{array}$} \\
\hline & $(1)$ & $(2)$ & $(3)$ & $(4)$ & (5) & $(6)$ \\
\hline $\begin{array}{l}\text { At least one adopter in } \\
\text { network }\end{array}$ & $\begin{array}{l}0.18^{*} \\
(0.10)\end{array}$ & & $\begin{array}{c}0.08 \\
(0.11)\end{array}$ & & $\begin{array}{c}0.28^{* * *} \\
(0.11)\end{array}$ & \\
\hline $\begin{array}{l}\text { At least one adopter in } \\
\text { network (water savers) }\end{array}$ & & $\begin{array}{c}0.12 \\
(0.14) \\
{[0.96]}\end{array}$ & & $\begin{array}{c}0.02 \\
(0.14) \\
{[0.90]}\end{array}$ & & $\begin{array}{c}0.11 \\
(0.14) \\
{[0.37]}\end{array}$ \\
\hline $\begin{array}{l}\text { At least one adopter in } \\
\text { network (nonsavers) }\end{array}$ & & $\begin{array}{c}0.13 \\
(0.15)\end{array}$ & & $\begin{array}{c}0.05 \\
(0.15)\end{array}$ & & $\begin{array}{l}0.30 * * \\
(0.15)\end{array}$ \\
\hline $\begin{array}{l}\text { One qualifying farmer in } \\
\text { network }\end{array}$ & $\begin{array}{l}-0.00 \\
(0.08)\end{array}$ & & $\begin{array}{l}-0.01 \\
(0.08)\end{array}$ & & $\begin{array}{c}-0.30 * * * \\
(0.08)\end{array}$ & \\
\hline $\begin{array}{l}\text { Two qualifying farmers in } \\
\text { network }\end{array}$ & $\begin{array}{l}-0.17 \\
(0.16)\end{array}$ & & $\begin{array}{l}-0.05 \\
(0.16)\end{array}$ & & $\begin{array}{l}-0.30^{*} \\
(0.16)\end{array}$ & \\
\hline $\begin{array}{l}\text { Three qualifying farmers in } \\
\text { network }\end{array}$ & $\begin{array}{c}0.06 \\
(0.24)\end{array}$ & & $\begin{array}{c}0.19 \\
(0.25)\end{array}$ & & $\begin{array}{c}-0.50^{* *} \\
(0.25)\end{array}$ & \\
\hline $\begin{array}{l}\text { Four qualifying farmers in } \\
\text { network }\end{array}$ & $\begin{array}{r}0.25 \\
-0.00\end{array}$ & & $\begin{array}{l}0.47 \\
-0.01\end{array}$ & & $\begin{array}{l}-1.31 * * \\
-0.30^{* * *}\end{array}$ & \\
\hline $\begin{array}{l}\text { One qualifying farmer in } \\
\text { network (water savers) }\end{array}$ & & $\begin{array}{c}0.04 \\
(0.10)\end{array}$ & & $\begin{array}{c}0.01 \\
(0.10)\end{array}$ & & $\begin{array}{l}-0.13 \\
(0.10)\end{array}$ \\
\hline $\begin{array}{l}\text { Two qualifying farmers in } \\
\text { network (water savers) }\end{array}$ & & $\begin{array}{l}-0.04 \\
(0.21)\end{array}$ & & $\begin{array}{l}-0.09 \\
(0.21)\end{array}$ & & $\begin{array}{l}-0.16 \\
(0.21)\end{array}$ \\
\hline $\begin{array}{l}\text { Three qualifying farmers in } \\
\text { network (water savers) }\end{array}$ & & $\begin{array}{c}0.38 \\
(0.58)\end{array}$ & & $\begin{array}{c}0.49 \\
(0.59)\end{array}$ & & $\begin{array}{c}0.04 \\
(0.59)\end{array}$ \\
\hline $\begin{array}{l}\text { One qualifying farmer in } \\
\text { network (nonsavers) }\end{array}$ & & $\begin{array}{l}-0.04 \\
(0.10)\end{array}$ & & $\begin{array}{c}0.04 \\
(0.10)\end{array}$ & & $\begin{array}{c}-0.28 * * * \\
(0.10)\end{array}$ \\
\hline $\begin{array}{l}\text { Two qualifying farmers in } \\
\text { network (water-savers) }\end{array}$ & & $\begin{array}{c}0.02 \\
(0.22)\end{array}$ & & $\begin{array}{c}0.05 \\
(0.22)\end{array}$ & & $\begin{array}{l}-0.39 * \\
(0.22)\end{array}$ \\
\hline $\begin{array}{l}\text { Three qualifying farmers in } \\
\text { network (water-savers) }\end{array}$ & & $\begin{array}{l}-0.58 \\
(0.52)\end{array}$ & & $\begin{array}{c}0.45 \\
(0.53)\end{array}$ & & $\begin{array}{l}-0.93^{*} \\
(0.53)\end{array}$ \\
\hline $\begin{array}{l}\text { Four qualifying farmers in } \\
\text { network (water-savers) }\end{array}$ & & $\begin{array}{c}0.41 \\
(0.63)\end{array}$ & & $\begin{array}{c}0.55 \\
(0.65)\end{array}$ & & $\begin{array}{l}-1.27^{*} \\
(0.65)\end{array}$ \\
\hline Total network size & $\begin{array}{l}0.001 \\
(0.05)\end{array}$ & $\begin{array}{l}-0.02 \\
(0.05)\end{array}$ & $\begin{array}{l}-0.02 \\
(0.05)\end{array}$ & $\begin{array}{l}-0.02 \\
(0.05)\end{array}$ & $\begin{array}{c}0.07 \\
(0.05)\end{array}$ & $\begin{array}{c}0.06 \\
(0.05)\end{array}$ \\
\hline Age (10 years) & $\begin{array}{l}0.04 * * \\
(0.02)\end{array}$ & $\begin{array}{l}0.04 * * \\
(0.02)\end{array}$ & $\begin{array}{l}-0.01 \\
(0.02)\end{array}$ & $\begin{array}{l}-0.01 \\
(0.02)\end{array}$ & $\begin{array}{c}0.02 \\
(0.02)\end{array}$ & $\begin{array}{c}0.01 \\
(0.02)\end{array}$ \\
\hline Education (years) & $\begin{array}{l}0.01 * * \\
(0.00)\end{array}$ & $\begin{array}{l}0.01^{* *} \\
(0.00)\end{array}$ & $\begin{array}{l}0.01 * * \\
(0.00)\end{array}$ & $\begin{array}{l}0.01 * * \\
(0.00)\end{array}$ & $\begin{array}{c}0.00 \\
(0.00)\end{array}$ & $\begin{array}{c}0.00 \\
(0.00)\end{array}$ \\
\hline Constant & $\begin{array}{c}0.34^{* * *} \\
(0.09)\end{array}$ & $\begin{array}{c}0.34^{* * *} \\
(0.09)\end{array}$ & $\begin{array}{c}0.55^{* * *} \\
(0.10)\end{array}$ & $\begin{array}{c}0.54^{* * *} \\
(0.10)\end{array}$ & $\begin{array}{c}0.39 * * * \\
(0.09)\end{array}$ & $\begin{array}{c}0.40^{* * *} \\
(0.10)\end{array}$ \\
\hline Observations & 422 & 422 & 422 & 422 & 422 & 422 \\
\hline
\end{tabular}

Notes: Water-saving denotes using 14 percent less water in 2011-2012 than in 2010-2011. IV linear probability model with lottery winning farmers instrumenting for farmers receiving leveling. Standard errors in parenthesis; ${ }^{* * *} p<0.01,{ }^{* *} p<0.05,{ }^{*}$ $p<0.1$. P-value for difference between effect of water-saver and nonsaving network contacts is in brackets. Omitted indicator variable is for no in-network qualifying farmers. 
Table 8-Placebo test for spurious network effects

\begin{tabular}{|c|c|c|c|c|}
\hline Dependent variable: WTP 2011 & (1) & (2) & (3) & (4) \\
\hline At least one adopter in network & $\begin{array}{c}29.10 \\
(37.78)\end{array}$ & $\begin{array}{c}37.63 \\
(37.16)\end{array}$ & & \\
\hline At least one adopter in network (water-savers) & & & $\begin{array}{l}-19.84 \\
(49.00) \\
{[0.316]}\end{array}$ & $\begin{array}{l}-17.30 \\
(48.09) \\
{[0.649]}\end{array}$ \\
\hline At least one adopter in network (nonsavers) & & & $\begin{array}{c}52.39 \\
(52.90)\end{array}$ & $\begin{array}{c}44.40 \\
(51.84)\end{array}$ \\
\hline One qualifying farmer in network & $\begin{array}{c}21.31 \\
(29.58)\end{array}$ & $\begin{array}{c}13.93 \\
(29.16)\end{array}$ & & \\
\hline Two qualifying farmers in network & $\begin{array}{l}109.02 * \\
(57.03)\end{array}$ & $\begin{array}{l}95.97^{*} \\
(56.63)\end{array}$ & & \\
\hline Three qualifying farmers in network & $\begin{array}{c}39.57 \\
(86.83)\end{array}$ & $\begin{array}{c}30.49 \\
(86.86)\end{array}$ & & \\
\hline Four qualifying farmers in network & $\begin{array}{c}239.16 \\
(221.69)\end{array}$ & $\begin{array}{c}262.63 \\
(218.37)\end{array}$ & & \\
\hline One qualifying farmer in network (water savers) & & & $\begin{array}{c}46.61 \\
(34.97)\end{array}$ & $\begin{array}{c}41.40 \\
(34.43)\end{array}$ \\
\hline Two qualifying farmers in network (water savers) & & & $\begin{array}{l}88.73 \\
(74.14)\end{array}$ & $\begin{array}{l}56.58 \\
(74.33)\end{array}$ \\
\hline $\begin{array}{l}\text { Three qualifying farmers in network (water- } \\
\text { savers) }\end{array}$ & & & $\begin{array}{c}226.33 \\
(208.96)\end{array}$ & $\begin{array}{c}221.82 \\
(205.90)\end{array}$ \\
\hline One qualifying farmer in network (nonsavers) & & & $\begin{array}{c}43.94 \\
(34.66)\end{array}$ & $\begin{array}{c}43.86 \\
(34.15)\end{array}$ \\
\hline Two qualifying farmers in network (water-savers) & & & $\begin{array}{l}18.95 \\
(78.97)\end{array}$ & $\begin{array}{l}37.53 \\
(77.84)\end{array}$ \\
\hline $\begin{array}{l}\text { Three qualifying farmers in network (water- } \\
\text { savers) }\end{array}$ & & & $\begin{array}{l}-213.96 \\
(187.59)\end{array}$ & $\begin{array}{l}-157.00 \\
(185.12)\end{array}$ \\
\hline Four qualifying farmers in network (water-savers) & & & $\begin{array}{c}216.12 \\
(227.83)\end{array}$ & $\begin{array}{c}254.91 \\
(224.79)\end{array}$ \\
\hline Total network size & $\begin{array}{c}-6.36 \\
(17.19)\end{array}$ & $\begin{array}{l}-12.76 \\
(16.98)\end{array}$ & $\begin{array}{l}-6.02 \\
(17.93)\end{array}$ & $\begin{array}{l}-12.21 \\
(17.74)\end{array}$ \\
\hline Age (years) & & $\begin{array}{c}7.90 \\
(5.75)\end{array}$ & & $\begin{array}{c}6.91 \\
(5.71)\end{array}$ \\
\hline Education (years) & & $\begin{array}{c}4.50 * * * \\
(1.70)\end{array}$ & & $\begin{array}{c}4.57^{* * *} \\
(1.71)\end{array}$ \\
\hline Wealth index & & $\begin{array}{c}21.28^{* *} \\
(10.05)\end{array}$ & & $\begin{array}{l}\text { 19.54* } \\
\text { (10.11) }\end{array}$ \\
\hline Constant & $\begin{array}{c}182.65^{* * *} \\
(10.98)\end{array}$ & $\begin{array}{c}120.74 * * * \\
(34.27)\end{array}$ & $\begin{array}{c}179.62^{* * *} \\
(10.85)\end{array}$ & $\begin{array}{c}121.86^{* * * *} \\
(34.33)\end{array}$ \\
\hline Observations & 422 & 422 & 422 & 422 \\
\hline
\end{tabular}

Notes: Water-saving denotes using at least 10\% less water in 2011-2012 than in 2010-2011. IV regressions with lottery winning farmers instrumenting for farmers receiving leveling. Standard errors in parenthesis; ${ }^{* * *} p<0.01$, $* * p<0.05, * p<0.1$. P-value for difference between effect of water-saver and nonsaving network contacts is in brackets. Wealth index consists of house condition; ration card possession; landholdings; and ownership of cell phones, vehicles, TVs, satellite dish, and livestock. Omitted indicator variables are for no in-network would adopters, no in-network qualifying water savers, and qualifying nonsavers. 
Table 9-Network effects using alternate network types

\begin{tabular}{|c|c|c|c|c|c|c|}
\hline \multirow[t]{2}{*}{$\begin{array}{l}\text { Dependent variable: } \\
\text { WTP } 2012\end{array}$} & \multicolumn{2}{|c|}{$\begin{array}{c}\text { Friends and family (FF), } \\
\text { unidirectional }\end{array}$} & \multicolumn{2}{|c|}{$\begin{array}{l}\text { Friends and family (FF), } \\
\text { bidirectional }\end{array}$} & \multicolumn{2}{|c|}{$\begin{array}{l}\text { Agricultural contacts, } \\
\text { bidirectional }\end{array}$} \\
\hline & (1) & (2) & (3) & (4) & (5) & (6) \\
\hline $\begin{array}{l}\text { At least one adopter in } \\
\text { network }\end{array}$ & $\begin{array}{c}25.01 \\
(37.92)\end{array}$ & & $\begin{array}{c}20.66 \\
(28.80)\end{array}$ & & $\begin{array}{c}50.52 \\
(33.51)\end{array}$ & \\
\hline $\begin{array}{l}\text { At least one adopter in } \\
\text { network (water-savers) }\end{array}$ & & $\begin{array}{c}50.62 \\
(40.49) \\
{[0.048]}\end{array}$ & & $\begin{array}{l}60.15^{*} \\
(32.44) \\
{[0.127]}\end{array}$ & & $\begin{array}{c}115.85^{* * *} \\
(37.87) \\
{[0.008]}\end{array}$ \\
\hline $\begin{array}{l}\text { At least one adopter in } \\
\text { network (nonsavers) }\end{array}$ & & $\begin{array}{l}-63.15 \\
(46.19)\end{array}$ & & $\begin{array}{l}-27.24 \\
(38.14)\end{array}$ & & $\begin{array}{l}-38.39 \\
(43.25)\end{array}$ \\
\hline $\begin{array}{l}\text { Control for number of would } \\
\text { be adopters, dummy variables }\end{array}$ & Yes & Yes & Yes & & & \\
\hline $\begin{array}{l}\text { Control for number of } \\
\text { qualifying farmers (water- } \\
\text { savers), dummy variables }\end{array}$ & & & & Yes & Yes & Yes \\
\hline $\begin{array}{l}\text { Control for number of } \\
\text { qualifying farmers } \\
\text { (nonsavers), dummy variables }\end{array}$ & & & & Yes & Yes & Yes \\
\hline Total network size & $\begin{array}{c}-8.89 \\
(11.80)\end{array}$ & $\begin{array}{l}-12.56 \\
(11.68)\end{array}$ & $\begin{array}{l}-6.79 \\
(8.97)\end{array}$ & $\begin{array}{l}-8.38 \\
(8.60)\end{array}$ & $\begin{array}{c}-3.31 \\
(11.07)\end{array}$ & $\begin{array}{c}0.83 \\
(11.32)\end{array}$ \\
\hline Age (years) & $\begin{array}{l}-0.63 \\
(5.93)\end{array}$ & $\begin{array}{l}-0.28 \\
(5.82)\end{array}$ & $\begin{array}{c}0.79 \\
(5.91)\end{array}$ & $\begin{array}{l}-3.44 \\
(5.86)\end{array}$ & $\begin{array}{l}-2.17 \\
(5.94)\end{array}$ & $\begin{array}{l}-2.04 \\
(5.82)\end{array}$ \\
\hline Education (years) & $\begin{array}{c}0.65 \\
(1.80)\end{array}$ & $\begin{array}{c}1.26 \\
(1.79)\end{array}$ & $\begin{array}{c}0.49 \\
(1.81)\end{array}$ & $\begin{array}{c}0.38 \\
(1.81)\end{array}$ & $\begin{array}{c}0.12 \\
(1.79)\end{array}$ & $\begin{array}{c}0.31 \\
(1.77)\end{array}$ \\
\hline Wealth index & $\begin{array}{c}10.62 \\
(10.96)\end{array}$ & $\begin{array}{c}12.26 \\
(10.39)\end{array}$ & $\begin{array}{c}12.05 \\
(10.79)\end{array}$ & $\begin{array}{l}19.34 * \\
(10.57)\end{array}$ & $\begin{array}{c}9.91 \\
(10.81)\end{array}$ & $\begin{array}{c}8.74 \\
(10.81)\end{array}$ \\
\hline WTP 2011 (Rs./hour) & $\begin{array}{c}0.27^{* * *} \\
(0.05)\end{array}$ & $\begin{array}{c}0.25 * * * \\
(0.05)\end{array}$ & $\begin{array}{c}0.26 * * * \\
(0.05)\end{array}$ & $\begin{array}{c}0.27^{* * *} \\
(0.05)\end{array}$ & $\begin{array}{c}0.26 * * * \\
(0.05)\end{array}$ & $\begin{array}{c}0.25 * * * \\
(0.05)\end{array}$ \\
\hline Constant & $\begin{array}{c}252.54^{* * *} \\
(36.50)\end{array}$ & $\begin{array}{c}252.42 * * * \\
(35.78)\end{array}$ & $\begin{array}{c}247.52 * * * \\
(35.66)\end{array}$ & $\begin{array}{c}250.86 * * * \\
(35.23)\end{array}$ & $\begin{array}{c}246.31 * * * \\
(36.79)\end{array}$ & $\begin{array}{c}271.64 * * * \\
(36.43)\end{array}$ \\
\hline Observations & 422 & 422 & 422 & 422 & 422 & 422 \\
\hline
\end{tabular}

Notes: Water-saving denotes using at least 10\% less water in 2011-2012 than in 2010-2011. IV regressions with lottery winning farmers instrumenting for farmers receiving leveling. Standard errors in parenthesis; $* * * \mathrm{p}<0.01$, ** $\mathrm{p}<0.05, * \mathrm{p}<0.1$. P-value for difference between effect of water-saver and nonsaving network contacts is in brackets. Wealth index consists of house condition; ration card possession; landholdings; and ownership of cell phones, vehicles, TVs, satellite dish, and livestock. 


\section{Appendix A: Auction protocol}

This document describes the structure and content of the experimental auction we will use to elicit farmers' valuation of laser land leveling (LLL) and to randomize the delivery of LLL services to interested farmers. We will involve all of our sample farmers in these auctions. Prior to launching the final auction in a particular village, the project manager / coordinator will have to arrange a location, date, and time for each phase of the auction so these details can be included in farmers' auction invitation.

\section{Welcome and introduction:}

"Thank you for participating in this auction. As a token of our appreciation, we have given each of you Rs. 100 as you arrived today. This money is yours to keep. During this auction, you will work with a helper (enumerator). At any point, if you have questions, feel free to ask your helper.

"Last year we introduced you to laser land leveling. We then conducted the same kind of auction as we will conduct today. Just like in last year's auction, in today's session we will give you an opportunity to custom hire LLL services for your own land. Compared to last year, you may know more this year about LLL because you may have seen how it works on your own land or on the land of another farmer. We hope this will help you assess more accurately how valuable you think LLL would be on your own land. Before we continue, do you have any questions about LLL?"

"Just like last year, we will use a simple market exercise to give you a chance to hire LLL services for your own plots. Because you may actually purchase these services, it is important for you to understand how the market exercise will work. The market exercise is not a competitive auction. This means that you will never be competing against the other farmers in the market exercise. This makes your job easy: All you have to do is determine how much you think LLL services are worth to you-without regard to how much the same LLL services may be worth to other farmers."

"Before we continue we would like to emphasize two points:

1. Each of you is different and has unique plots. These differences may mean that, at a given price, you choose to purchase LLL services for your plots while another farmer may not. This is perfectly normal. Because we want to know what you think, we will keep conversations with your helper as private as possible.

2. Your participation in this auction and the survey is part of a research project. As such, we are here as a research team, not a sales team. We are not here to promote LLL. We simply want to understand how beneficial you think LLL would be to you as a farmer." 


\section{Practice auction:}

"Since these market exercises will eventually involve real money and real LLL services, we want to be certain that you understand the market process. To help you, we will conduct a practice sweets auction using sweets to demonstrate how the auction will work."

"We have sweet $\mathrm{X}$ available for purchase. <Describe sweet in detail.> Does anyone have any questions about this sweet?"

"In order for you to actually buy sweets today and participate in the practice sweets auction, we will give you Rs. 20. You can use this money to buy sweets or keep as you like."

"We would like to know if you would be willing to purchase sweet $X$ at different prices. We will begin with a practice round to demonstrate how the market exercise will work. Your helper will ask you this question for several different prices. Please talk with your helper privately. Each helper will take you to a private place in this area to ensure that your conversations remain private."

Each worker will work separately and quietly with each farmer to complete the first pricing card. Start by asking, "If sweet $X$ cost Rs. 2, would you want to purchase it?" Put a checkmark in the box under 2 if he says "Yes." Continue asking for Rs. 4, Rs. 6, etc. until he says "No." At this point, say, "It sounds like you are not willing to pay more than [highest price with a checkmark] for sweet $X$. Is this right?" Once he is satisfied, turn to the next farmer and conduct the same procedure.

NOTE: The farmer need not see or have his/her attention focused on the pricing card. As much as possible, this process should be oral. Showing the pricing card will confuse or intimidate some farmers.

\begin{tabular}{|c|c|c|c|c|c|c|c|}
\hline 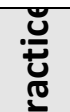 & 1 & $\begin{array}{l}\text { Price of each sweet } \\
\text { (Rs.): }\end{array}$ & 2 & 4 & 6 & 8 & 10 \\
\hline$\overline{2}$ & 2 & Purchase sweet X? & $\checkmark$ & $\checkmark$ & $\checkmark$ & & \\
\hline 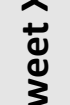 & 3 & $\begin{array}{l}\text { Price card drawn } \\
\text { (circle) }\end{array}$ & 2 & 4 & 6 & 8 & 10 \\
\hline & 4 & Total purchase price & & & & & \\
\hline
\end{tabular}

"Now that you've completed your purchase decision (row 2), we'll describe how we will determine the price of the sweet. We asked you whether you were willing to buy sweet X at 5 different prices. We have prepared 5 cards with each of these prices."

Show each card separately and announce the price as you hold up the card for everyone to see. 
"To determine what the price will be, we will mix up these cards and ask one of you to choose one. The price card that is drawn will be the price."

Have one of the farmers draw a price card. Hold up and announce the drawn card. Explain that if they said they would like to buy sweet $X$ at this price, this is the price they will pay. Each helper will circle the corresponding price on the pricing cards of the farmers they are helping.

Emphasize that in this market exercise they must consider their decision at each price carefully because they do not know which price could be the real price in the exercise. As long as they make their decision at each price carefully, they will be happy no matter what price is drawn. That is, if the price is higher than their checkmarks, they will be happy that they didn't get the sweet because the price is too high. If the price is below their highest checkmark, they will be happy that they are able the purchase the sweet at such a price. Tell the participants to ask their helpers if they have any questions.

"We will now conduct a real market exercise for sweets. This time you will pay real money for real sweets. This market will be like the first, except we will also offer a second sweet, sweet $Y$, for purchase. $<$ Describe sweet $Y$.> Just like the first time, we will ask you about 5 potential prices. For each of these prices, your job is to decide whether you would like to buy sweet $\mathrm{X}$ or sweet $\mathrm{Y}$ or both. Just like before, remember: it is important that you would be happy with any of your decisions because you don't know what the price will be."

Each enumerator will work privately with his farmer to complete the next pricing card. We will always talk through the prices and purchasing decisions by column. This means that the conversation will start with something like this: "If the price was Rs. 2, would you choose to purchase sweet X or sweet $Y$ or both?" Continue asking this question for each price and checking the appropriate boxes. Remind the farmer as needed that any of the prices could be drawn, so they need to make sure they would be happy with their purchase decision no matter what price is drawn.

\begin{tabular}{|c|c|c|c|c|c|c|c|}
\hline \multirow{5}{*}{ 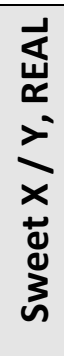 } & 1 & $\begin{array}{l}\text { Price of each sweet } \\
\text { (Rs.): }\end{array}$ & 2 & 4 & 6 & 8 & 10 \\
\hline & $2 \mathbf{i}$ & Purchase sweet X? & 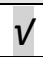 & 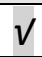 & 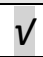 & $\checkmark$ & $\sqrt{ }$ \\
\hline & $2 \mathrm{ii}$ & Purchase sweet Y? & $\sqrt{ }$ & 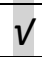 & & & \\
\hline & 3 & $\begin{array}{l}\text { Price card drawn } \\
\text { (circle) }\end{array}$ & 2 & 4 & 6 & 8 & 10 \\
\hline & 4 & Total purchase price & & & & & \\
\hline
\end{tabular}

"Now that you've made your decisions, we will determine the sweet price. Instead of drawing a price now as we did before, we drew the price card before and put it in this envelope. Just like 
before, you have to decide whether to purchase the sweets at each price without knowing what the price will be. This means you must consider each price carefully so you are happy with your decision no matter what price is in this envelope."

Hold up the card and announce the price. Explain that if they decided to buy one of the two sweets at that price, they will pay that price and get the sweet. If they decided to buy both sweets at that price, they will pay that price for each sweet-meaning they would pay a total of two times the price and get both sweets.

"Now, let's see what price card is in this envelope."

Have a farmer pull out the card, hold it up and announce the price. Conduct transactions as necessary.

"Any questions about how this market exercise works?"

\section{LLL services auction:}

"Now that you understand how the market works and are familiar with LLL, we are ready to proceed to the market exercise for actual LLL services on your land. This market for LLL services will be similar to the sweets auction. Just like before, your job is to decide which plots of your land, if any, you would like to have leveled at different LLL prices. Just like before, the outcome of the real auction will be real: you will actually pay money to receive real LLL services on your land.

"While the LLL market exercise is very similar to the sweets market, there is one important difference: Just like last year, you will neither receive nor pay for the LLL services today. Instead, for any LLL services you purchase today, we will schedule a convenient time in the near future to level your land. In your village, we plan to schedule LLL services during the week of . You will pay for the services at that time. A member of our research team will be your contact and coordinator for these services. <Introduce the coordinator / monitor for the village.> If you purchase LLL services in today's market, you will work with him so you can coordinate when exactly your land will be leveled. Are there any questions about how we will arrange to schedule the leveling of your land if you purchase the services today?

"In the sweets market, we asked you whether you would like to buy two different kinds of sweets. In the LLL market, we will ask you whether you would like to purchase LLL services on different plots. Just like each type of sweet is different, each plot is unique. Before beginning, we need you to help identify the plots on which you will be bidding for laser land leveling services. Your enumerator has the names of the various plots you have discussed with our survey team over the past year and will discuss these plots with you to make sure we understand what plots you will be bidding on." 
Each enumerator will confirm with his farmers that the Intras-seasonal Survey (ISS) plot names match the auction plot names on the auction card (as copied from LimeSurvey). The enumerator will also confirm whether each plot was laser leveled before the previous kharif season. If there are any mismatches between plots, the enumerator will carefully work with the farmer to understand what auction plot corresponds to each ISS plot. The enumerator will then write the correct auction plot name next to each ISS plot and neatly cross out any errors. Likewise, if there is an error regarding the LLL status of a plot the enumerator will correct this on the paper survey. After making any changes, the enumerator will call over a supervisor to make sure these changes are made properly. These corrections will be put into LimeSurvey at the conclusion of today's auction.

"Now that we have confirmed what plots you will bid to have LLL service on, we will continue the LLL market exercise. Your helper will next ask you how long you think it will take to LLL each plot. You should base this estimate on what you have learned about LLL and on your familiarity of your plot. Keep in mind that the time it takes to level a plot will vary based on how big and how uneven the plot is. A very uneven plot that is one acre can take 8 hours, while a less uneven acre plot can take 3 hours. If you know about how long it might take to level one of your plots with conventional techniques, you can use this to help you estimate the LLL time: LLL should take a little more than half as long to level the same plot."

Enumerators will need careful training to be able to help their farmers to estimate the LLL time. They can remind the farmer of things they learned in the information session.

"Just like in the sweets market, your task is simply to decide whether or not you would like to level each of your plots at different prices. In the LLL market, we will ask you about each of 10 different prices. These 10 prices are the same as last year. . In recent years, across different states in India from different LLL service providers, the price of custom-hire LLL has ranged between about Rs. 400 and Rs. 800 per hour. Since most of the custom-hire LLL prices we will ask you about have actually been paid by farmers somewhere in India, it is important that you consider each price as if it could be a real price.

"Like the sweets market, we will draw a price card to determine which price will count. The price card that determines the LLL price in this year's auction may be different than last year's auction price. Since any of the 10 prices could be drawn, it is important to think carefully about each decision. Above all else, we want you to be happy with your decisions no matter which price card is drawn.

"You might remember that in last year's auction, we had limited capacity to level land and had to use a lottery to determine which farmers received and paid for LLL services. This year, we have more capacity to level. This means that every farmer who wants LLL services at the final drawn price will receive and pay for these services. You should make your decision carefully at 
each price because-in the real exercise-these decisions will determine whether you pay to have your land leveled."

There may be questions from some farmers - who remember the lottery well-about this change.

"Your helper will now ask you whether you would like to purchase LLL services for each of your plots at each price level. Please remember to keep your conversations private."

Enumerators will work with their farmers to complete the first LLL pricing card. This process will happen in two steps. First, talk about only the unleveled plots listed. They should work down each price column, asking, "Would you like to custom hire LLL for unlevelled plot A (name) at a price of Rs. 250 per hour?" Check the corresponding box if the answer is "Yes," proceed to the next plot: "For this Rs. 250 per hour, would you like to custom hire LLL for unleveled plot B (name)? For plot C (name)?" Then move to the next column: "For a price of Rs. 300 per hour, would you like to custom hire LLL for plot A? Plot B? Plot C?" Enumerators should ask each of their farmers to decide for each price and check the box accordingly. They should not skip around. After the enumerators are done talking about all unleveled plots, move to the list of leveled plots. Work down each price column, asking, "In the hypothetical situation that this plot A was not leveled last year, would you have liked to custom hire LLL at a price of Rs. 250 per hour?" Check the corresponding box if the answer is "Yes." Now proceed to the next leveled plot. Enumerators should ask each of their farmers to decide for each price and check the box accordingly.

Enumerators may need to walk through the total cost of leveling at each price to help farmers understand the implications of their bidding behavior on their total LLL bill.

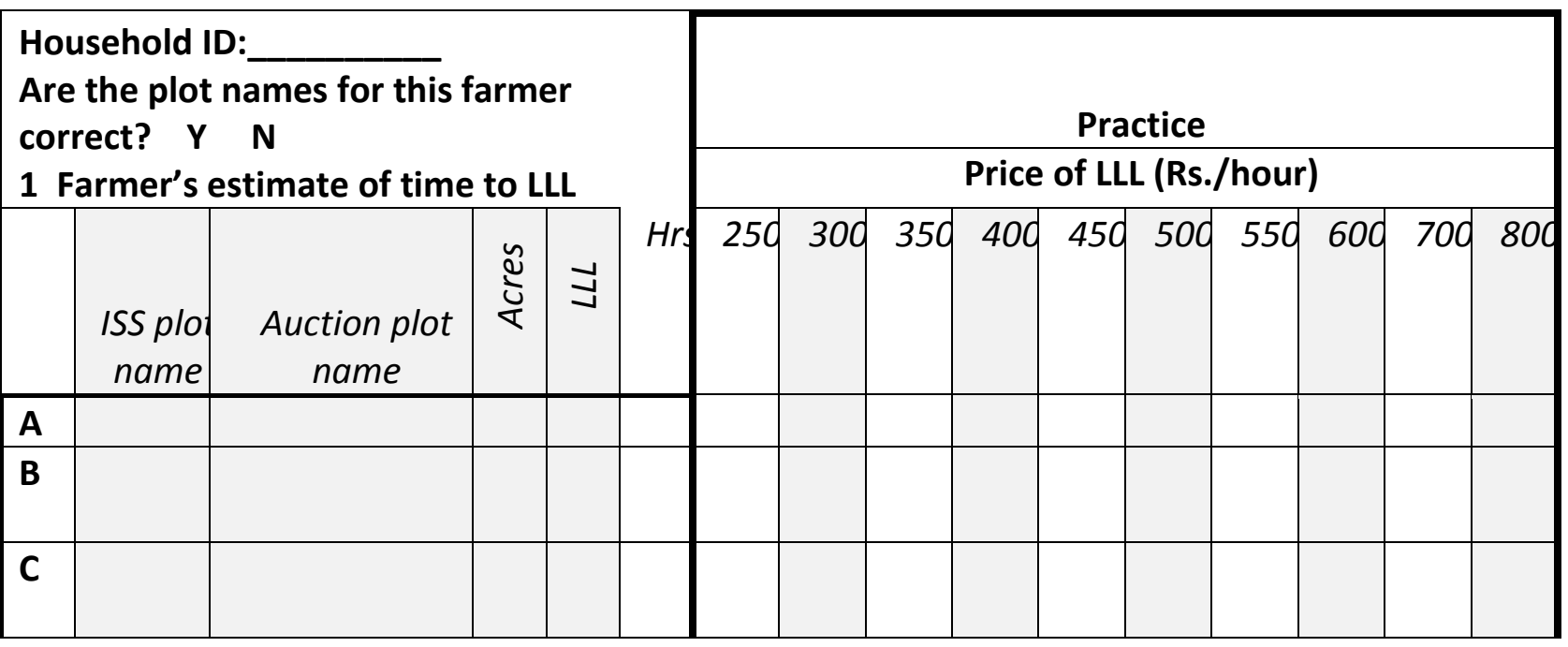


"Now that you have completed your LLL custom hire decisions, we are ready to determine the price for this practice exercise. We have one card for each price here."

Show each card and read the price, then put them in a pile and shuffle them up. To emphasize the potential range of prices, say, "Suppose we drew this Rs. $800 /$ hour card." Hold up the card. "For very uneven land, a 1-acre plot could cost over Rs. 6,000to level at this price. If the plot was fairly even, it could cost less than Rs. 2,000 to level." Move to a low card and say, "If instead we drew this Rs. 250/hour card, the uneven plot could cost Rs. 2,000 or more and the even plot could cost as little as Rs. 500. It is important for you to take each of the prices seriously."

"Just like last year and just like in the sweets auction, before this session began we drew one of these price cards and put it in this envelope. This price is likely different than the price card we drew last year. Let's pull this price card out to conclude this practice LLL market."

Have a farmer draw a price card. Announce the drawn price and have the enumerators discuss the outcome. The enumerators should discuss an estimated total cost based on the drawn price and the farmer's estimated LLL time per plot.

"In a moment, we will repeat this LLL market exercise for real. In that exercise, you may actually custom hire LLL on your land. If you do, you will pay the drawn price per hour of LLL service on each plot you want leveled. Based on your estimate of time required for LLL for each plot, you will know approximately how much the service will cost. When our provider actually levels your plots, the actual time required may be longer or shorter than your estimate. He will charge you based on the actual time it takes to completely level your land. We are committed to providing a high quality leveling service, and your coordinator (__ will accompany the provider to ensure excellent service.

"Are there any questions about how this LLL custom-hire service will be arranged or provided, or how the actual cost will be determined?

"Let's proceed with the real LLL market exercise. You've had one year to think about LLL and how valuable you think it would be on the plots you cultivate. Based on everything you've learned about LLL and know about your plots, you will now finalize your decisions for each price."

Enumerators will work with their farmers as above. Enumerators can copy over the plot details and then begin asking the questions as above. Those enumerators working with farmers who leveled plots will need to follow the mini-script above to elicit hypothetical WTP for leveled plots. 


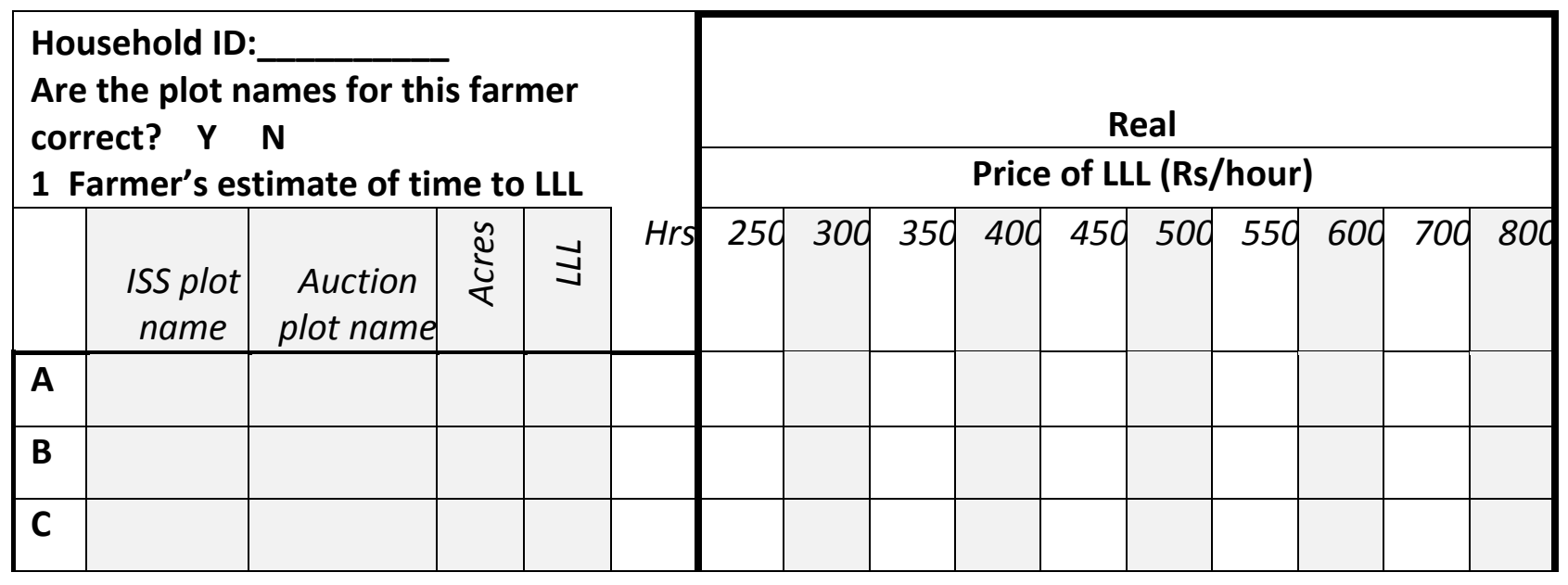

"Now that you've made your final decisions we will determine the price. Again, we have predrawn a price card and put it in this envelope. We will show you the price in this envelope in a minute and determine who buys and receives LLL services this year."

Set the envelope aside but somewhere visible so farmers can see that the envelope is waiting to be opened to reveal the real price. It is important that farmers understand that we are just pausing for a minute to ask a few more questions before wrapping up the auction.

"Before revealing the price in the envelope, we have one last market exercise for you that will help us understand even better how much you think LLL is worth to you. Like the practice auction, no one will receive LLL services based on this auction. Even though this auction is therefore hypothetical, we ask you-as a matter of self-respect and honesty-to make these auction decisions as if they were real."

We may want to allow enumerators to talk privately with their farmers to ensure full understanding of these points.

\section{[Credit module for 2012 only]}

"Like many agricultural inputs and services, agricultural credit or loans might be useful for financing LLL custom-hire services because these services can cost a lot of money. Several years ago, the government of India introduced the Kisan Credit Card to make it easier for farmers to get cash loans for agricultural purchases. We have discussed the possibility of using the Kisan Card to get a cash loan to pay for LLL with the lead bank in Gorakhpur. Soon, farmers may indeed be able to use a Kisan Card to get a short-term loan to pay for LLL. This loan would be repaid over 12 months at an interest rate of 7 percent.

"If you had the option of a Kisan Card loan on these terms to pay for LLL services on your plots, would you be interested? If so, would having the option of a Kisan Card loan change whether 
you would be willing to level each of your plots at different prices? Your helper will now help you respond to these important questions. As we mentioned before, although this is a hypothetical exercise, we ask you-as a matter of self-respect and honesty-to take these questions seriously and respond as if the exercise were real."

Enumerators now complete the Kisan Credit table with each of their farmers. They begin by repeating the question 'would you be interested?' If the farmer says, 'No' the enumerator should follow up with, "OK, so what you are saying is with a Kisan Card loan to pay for LLL you would not be willing to pay more for LLL on your plots?" If the farmer says s/he would be interested, the enumerator proceeds to fill out the Kisan Card table for each plot and price combination.

\begin{tabular}{|c|c|c|c|c|c|c|c|c|c|c|c|c|c|c|c|c|}
\hline \multicolumn{5}{|c|}{$\begin{array}{l}\text { Household ID: } \\
\text { Are the plot names for this farmer correct? } \\
\mathrm{N} \\
1 \text { Farmer's estimate of time to LLL }\end{array}$} & \multirow[b]{2}{*}{ Hrs } & \multicolumn{11}{|c|}{$\begin{array}{c}4 \text { Interested in credit for LLL? } \quad \boldsymbol{Y} \quad \mathbf{N} \\
\text { With credit option }\end{array}$} \\
\hline & $\begin{array}{l}\text { ISS plot } \\
\text { name }\end{array}$ & $\begin{array}{l}\text { Auction plot } \\
\text { name }\end{array}$ & $\frac{\varrho}{\grave{c}}$ & $\exists$ & & 250 & 300 & 350 & 400 & 450 & 500 & 550 & 600 & & & 80 \\
\hline A & & & & & & & & & & & & & & & & \\
\hline B & & & & & & & & & & & & & & & & \\
\hline C & & & & & & & & & & & & & & & & \\
\hline
\end{tabular}

"We thank you for your time and interest throughout this exercise. We are also very grateful for all the time you have given us over the past year. We will return after the rabi harvest to ask some final questions for all of you, whether or not you receive any laser land leveling. "We are now ready to reveal the price in this envelope. <Pick up the envelope from the visible place where it was placed.> Remember that this is the real price that corresponds to your decisions during the real LLL auction and will determine who receives LLL services and how much they will pay. Now, let's pull out the price card."

Pull out the card and announce the price. Enumerators will work privately with their farmers to determine what the final price means for them. Processing of forms and wrap-up. Enumerators should talk to the auction "winners" and the LLL monitor to determine feasible dates for scheduling of LLL services. All should be cognizant of the village's estimated date for completion of the wheat harvest, as LLL services can only be provided once harvest is complete. 


\section{APPENDIX B: Results using series of binary variables for number of lottery winning farmers to}

test for marginal effects of additional in-network adopters

\begin{tabular}{|c|c|c|c|c|}
\hline Dependent variable: WTP 2012 & $(1)$ & $(2)$ & (3) & (4) \\
\hline One lottery winner in network & $\begin{array}{l}80.09 * * \\
(32.19)\end{array}$ & $\begin{array}{l}78.68 * * \\
(31.42)\end{array}$ & & \\
\hline Two lottery winners in network & $\begin{array}{c}54.80 \\
(68.16)\end{array}$ & $\begin{array}{c}76.14 \\
(66.24)\end{array}$ & & \\
\hline Three lottery winners in network & $\begin{array}{c}99.31 \\
(152.50)\end{array}$ & $\begin{array}{c}152.13 \\
(148.63)\end{array}$ & & \\
\hline One lottery winning water-saver & & & $\begin{array}{c}128.83 * * * \\
(41.85)\end{array}$ & $\begin{array}{c}135.49 * * * \\
(40.53)\end{array}$ \\
\hline Two lottery winning water-savers & & & $\begin{array}{c}27.88 \\
(212.82)\end{array}$ & $\begin{array}{l}-44.65 \\
(206.49)\end{array}$ \\
\hline One lottery winning nonsaver & & & $\begin{array}{c}2.21 \\
(41.95)\end{array}$ & $\begin{array}{l}-10.43 \\
(40.53)\end{array}$ \\
\hline Two lottery winning nonsavers & & & $\begin{array}{c}-81.05 \\
(104.95)\end{array}$ & $\begin{array}{c}-57.84 \\
(101.70)\end{array}$ \\
\hline Three lottery winning nonsavers & & & $\begin{array}{c}16.14 \\
(189.97)\end{array}$ & $\begin{array}{c}64.40 \\
(184.43)\end{array}$ \\
\hline $\begin{array}{l}\text { Binary controls for number of } \\
\text { qualifying farmers }\end{array}$ & Yes & Yes & & \\
\hline $\begin{array}{l}\text { Binary controls for number of } \\
\text { qualifying water-savers }\end{array}$ & & & Yes & Yes \\
\hline $\begin{array}{l}\text { Binary controls for number of } \\
\text { qualifying nonsavers }\end{array}$ & & & Yes & Yes \\
\hline Total network size & $\begin{array}{c}-7.92 \\
(18.31)\end{array}$ & $\begin{array}{c}-6.25 \\
(17.85)\end{array}$ & $\begin{array}{c}-3.91 \\
(18.88)\end{array}$ & $\begin{array}{c}-3.15 \\
(18.40)\end{array}$ \\
\hline Age (10 years) & & $\begin{array}{l}-3.22 \\
(6.03)\end{array}$ & & $\begin{array}{l}-2.27 \\
(5.96)\end{array}$ \\
\hline Education (years) & & $\begin{array}{c}0.62 \\
(1.80)\end{array}$ & & $\begin{array}{c}0.85 \\
(1.79)\end{array}$ \\
\hline Wealth index & & $\begin{array}{c}14.98 \\
(10.67)\end{array}$ & & $\begin{array}{c}14.09 \\
(10.54)\end{array}$ \\
\hline WTP 2011 (Rs. 100/hour) & & $\begin{array}{c}0.27^{* * *} \\
(0.05)\end{array}$ & & $\begin{array}{c}0.26 * * * \\
(0.05)\end{array}$ \\
\hline Constant & $\begin{array}{c}295.82 * * * \\
(11.64)\end{array}$ & $\begin{array}{c}260.60 * * * \\
(36.33)\end{array}$ & $\begin{array}{c}295.60 * * * \\
(11.41)\end{array}$ & $\begin{array}{c}255.66 * * * \\
(36.14)\end{array}$ \\
\hline Observations & 422 & 422 & 422 & 422 \\
\hline
\end{tabular}


Table B2-Network effects on demand at various prices

\begin{tabular}{|c|c|c|c|c|c|c|c|c|}
\hline & (1) & $(2)$ & (3) & (4) & (5) & (6) & (7) & (8) \\
\hline Dependent variable: WTP 2012 & Rs. 250 & Rs.350 & Rs. 500 & Rs. 600 & Rs. 250 & Rs.350 & Rs.500 & Rs. 600 \\
\hline \multirow[t]{2}{*}{ One lottery winner in network } & $0.14 * *$ & $0.23 * * *$ & 0.09 & 0.06 & & & & \\
\hline & $(0.07)$ & $(0.09)$ & $(0.06)$ & $(0.05)$ & & & & \\
\hline \multirow[t]{2}{*}{ Two lottery winners in network } & $0.25 *$ & 0.06 & 0.03 & 0.01 & & & & \\
\hline & $(0.14)$ & $(0.18)$ & $(0.13)$ & $(0.11)$ & & & & \\
\hline \multirow[t]{2}{*}{ Three lottery winners in network } & 0.47 & -0.02 & 0.07 & 0.05 & & & & \\
\hline & $(0.32)$ & $(0.41)$ & (0.29) & $(0.24)$ & & & & \\
\hline \multirow[t]{2}{*}{ One lottery winning water-saver } & & & & & $0.25 * * *$ & $0.25 * *$ & $0.19 * *$ & $0.15^{* *}$ \\
\hline & & & & & $(0.09)$ & $(0.11)$ & $(0.08)$ & $(0.07)$ \\
\hline \multirow[t]{2}{*}{ Two lottery winning water-savers } & & & & & 0.01 & -0.38 & -0.21 & -0.19 \\
\hline & & & & & $(0.44)$ & $(0.57)$ & $(0.40)$ & $(0.33)$ \\
\hline \multirow[t]{2}{*}{ One lottery winning nonsaver } & & & & & -0.03 & 0.11 & -0.04 & -0.06 \\
\hline & & & & & (0.09) & $(0.11)$ & $(0.08)$ & $(0.07)$ \\
\hline \multirow[t]{2}{*}{ Two lottery winning nonsavers } & & & & & -0.03 & -0.11 & -0.25 & -0.04 \\
\hline & & & & & $(0.22)$ & $(0.28)$ & $(0.20)$ & $(0.16)$ \\
\hline \multirow[t]{2}{*}{ Three lottery winning nonsavers } & & & & & 0.27 & -0.28 & -0.09 & -0.05 \\
\hline & & & & & $(0.40)$ & $(0.51)$ & $(0.36)$ & $(0.30)$ \\
\hline $\begin{array}{l}\text { Binary controls for number of qualifying } \\
\text { farmers }\end{array}$ & Yes & Yes & Yes & Yes & Yes & Yes & Yes & Yes \\
\hline \multirow[t]{2}{*}{ Total network size } & 0.01 & -0.05 & -0.00 & 0.01 & 0.01 & -0.04 & 0.00 & 0.01 \\
\hline & $(0.04)$ & $(0.05)$ & $(0.03)$ & $(0.03)$ & $(0.04)$ & $(0.05)$ & $(0.04)$ & $(0.03)$ \\
\hline Controls (Age, Education, Wealth, 2011 WTP) & Yes & Yes & Yes & Yes & Yes & Yes & Yes & Yes \\
\hline \multirow[t]{2}{*}{ Constant } & $0.74 * * *$ & $0.42 * * *$ & 0.10 & 0.03 & $0.74 * * *$ & $0.41 * * *$ & 0.09 & 0.02 \\
\hline & $(0.08)$ & $(0.10)$ & $(0.07)$ & $(0.06)$ & $(0.08)$ & $(0.10)$ & $(0.07)$ & $(0.06)$ \\
\hline Observations & 422 & 422 & 422 & 422 & 422 & 422 & 422 & 422 \\
\hline
\end{tabular}

Notes: Water-saving denotes using 14 percent less water in 2011-2012 than in 2010-2011. OLS regressions OLS regressions (IV is not identified).

Standard errors in parenthesis; ${ }^{* * *} p<0.01,{ }^{* *} p<0.05, * p<0.1$. 
Table B3-Network effects on mode of exposure to LLL

\begin{tabular}{|c|c|c|c|c|c|c|}
\hline \multirow[t]{2}{*}{ Exposure to LLL through... } & \multicolumn{2}{|c|}{$\begin{array}{l}\text {... conversation with } \\
\text { adopting farmer about LLL }\end{array}$} & \multicolumn{2}{|c|}{$\begin{array}{l}\text {...seeing LLL unit } \\
\text { operate }\end{array}$} & \multicolumn{2}{|c|}{$\begin{array}{c}\text {...observing field of } \\
\text { adopting farmer }\end{array}$} \\
\hline & $(1)$ & $(2)$ & (3) & (4) & $(5)$ & (6) \\
\hline $\begin{array}{l}\text { One lottery winner in } \\
\text { network }\end{array}$ & $\begin{array}{c}0.13 \\
(0.09)\end{array}$ & & $\begin{array}{c}0.05 \\
(0.09)\end{array}$ & & $\begin{array}{c}0.24 * * * \\
(0.09)\end{array}$ & \\
\hline $\begin{array}{l}\text { Two lottery winners in } \\
\text { network }\end{array}$ & $\begin{array}{l}0.15 \\
(0.18)\end{array}$ & & $\begin{array}{c}0.15 \\
(0.19)\end{array}$ & & $\begin{array}{l}-0.11 \\
(0.18)\end{array}$ & \\
\hline $\begin{array}{l}\text { Three lottery winners in } \\
\text { network }\end{array}$ & $\begin{array}{l}-0.24 \\
(0.41)\end{array}$ & & $\begin{array}{c}0.41 \\
(0.42)\end{array}$ & & $\begin{array}{c}0.16 \\
(0.41)\end{array}$ & \\
\hline $\begin{array}{l}\text { One lottery winning water- } \\
\text { saver }\end{array}$ & & $\begin{array}{c}0.09 \\
(0.11)\end{array}$ & & $\begin{array}{c}0.01 \\
(0.11)\end{array}$ & & $\begin{array}{c}0.09 \\
(0.11)\end{array}$ \\
\hline $\begin{array}{l}\text { Two lottery winning water- } \\
\text { savers }\end{array}$ & & $\begin{array}{c}0.53 \\
(0.57)\end{array}$ & & $\begin{array}{c}0.52 \\
(0.58)\end{array}$ & & $\begin{array}{c}0.18 \\
(0.58)\end{array}$ \\
\hline $\begin{array}{l}\text { One lottery winning } \\
\text { nonsaver }\end{array}$ & & $\begin{array}{c}0.11 \\
(0.11)\end{array}$ & & $\begin{array}{c}0.04 \\
(0.11)\end{array}$ & & $\begin{array}{c}0.23^{* *} \\
(0.11)\end{array}$ \\
\hline $\begin{array}{l}\text { Two lottery winning } \\
\text { nonsavers }\end{array}$ & & $\begin{array}{c}0.21 \\
(0.28)\end{array}$ & & $\begin{array}{c}0.45 \\
(0.29)\end{array}$ & & $\begin{array}{c}0.10 \\
(0.29)\end{array}$ \\
\hline $\begin{array}{l}\text { Three lottery winning } \\
\text { nonsavers }\end{array}$ & & $\begin{array}{l}-0.46 \\
(0.51)\end{array}$ & & $\begin{array}{c}0.49 \\
(0.52)\end{array}$ & & $\begin{array}{l}-0.65 \\
(0.52)\end{array}$ \\
\hline $\begin{array}{l}\text { Binary controls for number } \\
\text { of qualifying farmers }\end{array}$ & Yes & & Yes & & Yes & \\
\hline $\begin{array}{l}\text { Binary controls for number } \\
\text { of qualifying water-savers }\end{array}$ & & Yes & & Yes & & Yes \\
\hline $\begin{array}{l}\text { Binary controls for number } \\
\text { of qualifying nonsavers }\end{array}$ & & Yes & & Yes & & Yes \\
\hline Total network size & $\begin{array}{l}-0.00 \\
(0.05)\end{array}$ & $\begin{array}{l}-0.02 \\
(0.05)\end{array}$ & $\begin{array}{l}-0.02 \\
(0.05)\end{array}$ & $\begin{array}{l}-0.03 \\
(0.05)\end{array}$ & $\begin{array}{c}0.08 \\
(0.05)\end{array}$ & $\begin{array}{c}0.06 \\
(0.05)\end{array}$ \\
\hline Age (10 years) & $\begin{array}{l}0.04 * * \\
(0.02)\end{array}$ & $\begin{array}{l}0.04 * * \\
(0.02)\end{array}$ & $\begin{array}{l}-0.01 \\
(0.02)\end{array}$ & $\begin{array}{l}-0.01 \\
(0.02)\end{array}$ & $\begin{array}{c}0.02 \\
(0.02)\end{array}$ & $\begin{array}{c}0.02 \\
(0.02)\end{array}$ \\
\hline Education (years) & $\begin{array}{c}0.01 * * \\
(0.00)\end{array}$ & $\begin{array}{c}0.01 * * \\
(0.00)\end{array}$ & $\begin{array}{l}0.01 * * \\
(0.00)\end{array}$ & $\begin{array}{l}0.01 * * \\
(0.00)\end{array}$ & $\begin{array}{c}0.01 \\
(0.00)\end{array}$ & $\begin{array}{c}0.01 \\
(0.01)\end{array}$ \\
\hline Wealth index & $\begin{array}{l}-0.04 \\
(0.03)\end{array}$ & $\begin{array}{l}-0.04 \\
(0.03)\end{array}$ & $\begin{array}{l}-0.02 \\
(0.03)\end{array}$ & $\begin{array}{l}-0.01 \\
(0.03)\end{array}$ & $\begin{array}{c}-0.05 \\
(0.03)\end{array}$ & $\begin{array}{c}-0.06^{* *} \\
(0.03)\end{array}$ \\
\hline Constant & $\begin{array}{c}0.30 * * * \\
(0.10)\end{array}$ & $\begin{array}{c}0.31 * * * \\
(0.10)\end{array}$ & $\begin{array}{c}0.53 * * * \\
(0.10)\end{array}$ & $\begin{array}{c}0.54 * * * \\
(0.10)\end{array}$ & $\begin{array}{c}0.34 * * * \\
(0.10)\end{array}$ & $\begin{array}{c}0.34 * * * \\
(0.10)\end{array}$ \\
\hline Observations & 422 & 422 & 422 & 422 & 422 & 422 \\
\hline
\end{tabular}

Notes: Water-saving denotes using 14 percent less water in 2011-2012 than in 2010-2011. OLS regressions (IV is not identified). Standard errors in parenthesis; ${ }^{* * *} \mathrm{p}<0.01, * * \mathrm{p}<0.05, * \mathrm{p}<0.1$. 
Table B4-Placebo test for spurious network effects

\begin{tabular}{|c|c|c|c|c|}
\hline Dependent variable: WTP 2011 & $(1)$ & $(2)$ & (3) & (4) \\
\hline One lottery winner in network & $\begin{array}{c}31.81 \\
(30.60)\end{array}$ & $\begin{array}{c}40.82 \\
(30.27)\end{array}$ & & \\
\hline Two lottery winners in network & $\begin{array}{l}-93.21 \\
(64.78)\end{array}$ & $\begin{array}{c}-105.68^{*} \\
(63.74)\end{array}$ & & \\
\hline Three lottery winners in network & $\begin{array}{c}-53.01 \\
(144.94)\end{array}$ & $\begin{array}{c}17.42 \\
(143.49)\end{array}$ & & \\
\hline One lottery winning water-saver & & & $\begin{array}{l}-15.23 \\
(40.23)\end{array}$ & $\begin{array}{l}-13.46 \\
(39.74)\end{array}$ \\
\hline Two lottery winning water-savers & & & $\begin{array}{c}197.81 \\
(204.59)\end{array}$ & $\begin{array}{c}199.58 \\
(202.26)\end{array}$ \\
\hline One lottery winning nonsaver & & & $\begin{array}{c}39.30 \\
(40.33)\end{array}$ & $\begin{array}{c}33.32 \\
(39.71)\end{array}$ \\
\hline Two lottery winning nonsavers & & & $\begin{array}{c}-47.32 \\
(100.89)\end{array}$ & $\begin{array}{l}-44.14 \\
(99.71)\end{array}$ \\
\hline Three lottery winning nonsavers & & & $\begin{array}{l}-165.84 \\
(182.62)\end{array}$ & $\begin{array}{l}-114.67 \\
(180.78)\end{array}$ \\
\hline Binary controls for number of qualifying farmers & Yes & Yes & & \\
\hline $\begin{array}{l}\text { Binary controls for number of qualifying water- } \\
\text { savers }\end{array}$ & & & Yes & Yes \\
\hline Binary controls for number of qualifying nonsavers & & & Yes & Yes \\
\hline Total network size & $\begin{array}{c}-3.74 \\
(17.41)\end{array}$ & $\begin{array}{c}-8.70 \\
(17.23)\end{array}$ & $\begin{array}{c}-4.55 \\
(18.15)\end{array}$ & $\begin{array}{l}-11.18 \\
(18.03)\end{array}$ \\
\hline Age (10 years) & & $\begin{array}{c}7.76 \\
(5.81)\end{array}$ & & $\begin{array}{c}7.48 \\
(5.83)\end{array}$ \\
\hline Education (years) & & $\begin{array}{c}4.47 * * * \\
(1.72)\end{array}$ & & $\begin{array}{c}4.67 * * * \\
(1.74)\end{array}$ \\
\hline Wealth index & & $\begin{array}{c}23.99 * * \\
(10.24)\end{array}$ & & $\begin{array}{c}18.60 * \\
(10.29)\end{array}$ \\
\hline Constant & $\begin{array}{c}182.15^{* * *} \\
(11.06)\end{array}$ & $\begin{array}{c}121.13^{* * *} \\
(34.56)\end{array}$ & $\begin{array}{c}179.50 * * * \\
(10.97)\end{array}$ & $\begin{array}{c}118.31 * * * \\
(34.96)\end{array}$ \\
\hline Observations & 422 & 422 & 422 & 422 \\
\hline
\end{tabular}


Table B5-Network effects using alternate network types

\begin{tabular}{|c|c|c|c|c|c|c|}
\hline \multirow[t]{2}{*}{$\begin{array}{l}\text { Dependent variable: } \\
\text { WTP } 2012\end{array}$} & \multicolumn{2}{|c|}{$\begin{array}{c}\text { Friends and family (FF), } \\
\text { unidirectional }\end{array}$} & \multicolumn{2}{|c|}{$\begin{array}{c}\text { Friends and family (FF), } \\
\text { bidirectional }\end{array}$} & \multicolumn{2}{|c|}{$\begin{array}{l}\text { Agricultural contacts, } \\
\text { bidirectional }\end{array}$} \\
\hline & (1) & (2) & (3) & (4) & (5) & (6) \\
\hline $\begin{array}{l}\text { One lottery winner in } \\
\text { network }\end{array}$ & $\begin{array}{c}19.78 \\
(32.34)\end{array}$ & & $\begin{array}{c}16.42 \\
(26.43)\end{array}$ & & $\begin{array}{c}38.54 \\
(29.22)\end{array}$ & \\
\hline $\begin{array}{l}\text { Two lottery winners in } \\
\text { network }\end{array}$ & $\begin{array}{l}23.37 \\
(60.92)\end{array}$ & & $\begin{array}{c}24.50 \\
(40.53)\end{array}$ & & $\begin{array}{l}74.02 \\
(48.01)\end{array}$ & \\
\hline $\begin{array}{l}\text { Three lottery winners in } \\
\text { network }\end{array}$ & $\begin{array}{l}75.55 \\
(96.96)\end{array}$ & & $\begin{array}{c}36.15 \\
(65.71)\end{array}$ & & $\begin{array}{c}82.07 \\
(103.06)\end{array}$ & \\
\hline $\begin{array}{l}\text { Four lottery winners in } \\
\text { network }\end{array}$ & $\begin{array}{c}13.18 \\
(175.26)\end{array}$ & & $\begin{array}{c}-0.97 \\
(148.39)\end{array}$ & & $\begin{array}{c}57.55 \\
(207.04)\end{array}$ & \\
\hline $\begin{array}{l}\text { Five lottery winners in } \\
\text { network }\end{array}$ & & & $\begin{array}{c}-20.69 \\
(230.42)\end{array}$ & & & \\
\hline $\begin{array}{l}\text { Six lottery winners in } \\
\text { network }\end{array}$ & & & & & $\begin{array}{l}183.45 \\
(215.80)\end{array}$ & \\
\hline $\begin{array}{l}\text { One lottery winning water- } \\
\text { saver }\end{array}$ & & $\begin{array}{c}56.85 \\
(38.03)\end{array}$ & & $\begin{array}{l}71.47 * * \\
(31.98)\end{array}$ & & $\begin{array}{c}108.93 * * * \\
(34.95)\end{array}$ \\
\hline $\begin{array}{l}\text { Two lottery winning water- } \\
\text { savers }\end{array}$ & & $\begin{array}{c}23.40 \\
(81.83)\end{array}$ & & $\begin{array}{l}-7.63 \\
(59.16)\end{array}$ & & $\begin{array}{c}0.43 \\
(98.20)\end{array}$ \\
\hline $\begin{array}{l}\text { Three lottery winning } \\
\text { water-savers }\end{array}$ & & $\begin{array}{c}149.50 \\
(229.01)\end{array}$ & & $\begin{array}{c}195.93 \\
(158.38)\end{array}$ & & $\begin{array}{l}-234.35 \\
(275.75)\end{array}$ \\
\hline $\begin{array}{l}\text { One lottery winning } \\
\text { nonsaver }\end{array}$ & & $\begin{array}{l}-52.60 \\
(39.59)\end{array}$ & & $\begin{array}{l}-23.62 \\
(31.98)\end{array}$ & & $\begin{array}{l}-36.04 \\
(34.34)\end{array}$ \\
\hline $\begin{array}{l}\text { Two lottery winning } \\
\text { nonsavers }\end{array}$ & & $\begin{array}{l}14.21 \\
(87.76)\end{array}$ & & $\begin{array}{l}-29.86 \\
(58.74)\end{array}$ & & $\begin{array}{l}27.45 \\
(70.03)\end{array}$ \\
\hline $\begin{array}{l}\text { Three lottery winning } \\
\text { nonsavers }\end{array}$ & & $\begin{array}{l}154.60 \\
(293.07)\end{array}$ & & $\begin{array}{c}31.19 \\
(117.87)\end{array}$ & & $\begin{array}{c}28.43 \\
(156.07)\end{array}$ \\
\hline $\begin{array}{l}\text { Four lottery winning } \\
\text { nonsavers }\end{array}$ & & $\begin{array}{c}33.73 \\
(289.80)\end{array}$ & & $\begin{array}{c}-8.67 \\
(201.74)\end{array}$ & & $\begin{array}{c}-54.41 \\
(207.98)\end{array}$ \\
\hline $\begin{array}{l}\text { Binary controls for number } \\
\text { of qualifying farmers }\end{array}$ & Yes & Yes & Yes & Yes & Yes & Yes \\
\hline Total network size & $\begin{array}{c}-8.64 \\
(12.06)\end{array}$ & $\begin{array}{l}-14.28 \\
(12.23)\end{array}$ & $\begin{array}{l}-6.38 \\
(9.19)\end{array}$ & $\begin{array}{l}-8.93 \\
(8.98)\end{array}$ & $\begin{array}{c}-1.04 \\
(11.61)\end{array}$ & $\begin{array}{c}2.10 \\
(11.66)\end{array}$ \\
\hline Age (10 years) & $\begin{array}{l}-0.97 \\
(6.08)\end{array}$ & $\begin{array}{l}-0.92 \\
(6.02)\end{array}$ & $\begin{array}{c}0.08 \\
(6.13)\end{array}$ & $\begin{array}{l}-4.30 \\
(6.09)\end{array}$ & $\begin{array}{l}-2.80 \\
(6.07)\end{array}$ & $\begin{array}{l}-2.69 \\
(5.98)\end{array}$ \\
\hline Education (years) & $\begin{array}{c}0.68 \\
(1.84)\end{array}$ & $\begin{array}{c}1.32 \\
(1.84)\end{array}$ & $\begin{array}{c}0.39 \\
(1.87)\end{array}$ & $\begin{array}{c}0.44 \\
(1.87)\end{array}$ & $\begin{array}{c}0.13 \\
(1.82)\end{array}$ & $\begin{array}{c}0.16 \\
(1.81)\end{array}$ \\
\hline Wealth index & $\begin{array}{c}11.98 \\
(11.41)\end{array}$ & $\begin{array}{c}12.69 \\
(10.67)\end{array}$ & $\begin{array}{c}13.05 \\
(11.43)\end{array}$ & $\begin{array}{l}19.95^{*} \\
(10.89)\end{array}$ & $\begin{array}{c}8.78 \\
(11.02)\end{array}$ & $\begin{array}{c}8.80 \\
(11.03)\end{array}$ \\
\hline WTP 2011 (Rs. 100/hour) & $\begin{array}{c}0.26 * * * \\
(0.05)\end{array}$ & $\begin{array}{c}0.24^{* * *} \\
(0.05)\end{array}$ & $\begin{array}{c}0.27^{* * *} \\
(0.05)\end{array}$ & $\begin{array}{c}0.27^{* * *} \\
(0.05)\end{array}$ & $\begin{array}{c}0.27^{* * *} \\
(0.05)\end{array}$ & $\begin{array}{c}0.26 * * * \\
(0.05)\end{array}$ \\
\hline Constant & $\begin{array}{c}254.67^{* * *} \\
(37.38)\end{array}$ & $\begin{array}{c}257.96 * * * \\
(36.97)\end{array}$ & $\begin{array}{c}250.02^{* * *} \\
(38.08)\end{array}$ & $\begin{array}{c}276.64 * * * \\
(37.80)\end{array}$ & $\begin{array}{c}247.98^{* * *} \\
(36.37)\end{array}$ & $\begin{array}{c}251.31 * * * \\
(36.09)\end{array}$ \\
\hline Observations & 422 & 422 & 422 & 422 & 422 & 422 \\
\hline
\end{tabular}




\section{APPENDIX C: Results using continuous network variables}

Table C1-Network effects on demand for LLL

\begin{tabular}{|c|c|c|c|c|}
\hline Dependent variable: WTP 2012 & (1) & $(2)$ & (3) & (4) \\
\hline \# of adopters in network & $\begin{array}{l}58.83^{*} \\
(30.72)\end{array}$ & $\begin{array}{l}64.81^{* *} \\
(29.71)\end{array}$ & & \\
\hline $\begin{array}{l}\text { \# of adopters in network (water } \\
\text { savers) }\end{array}$ & & & $\begin{array}{c}159.84 * * * \\
(48.99) \\
{[0.003]}\end{array}$ & $\begin{array}{c}168.35^{* * *} \\
(47.20) \\
{[0.002]}\end{array}$ \\
\hline \# of adopters in network (nonsavers) & & & $\begin{array}{l}-33.85 \\
(42.29)\end{array}$ & $\begin{array}{l}-30.82 \\
(40.73)\end{array}$ \\
\hline \# of qualifying farmers in network & $\begin{array}{c}6.12 \\
(26.62)\end{array}$ & $\begin{array}{l}-10.72 \\
(26.03)\end{array}$ & & \\
\hline $\begin{array}{l}\text { \# of qualifying farmers in network } \\
\text { (water savers) }\end{array}$ & & & $\begin{array}{l}-42.25 \\
(31.59)\end{array}$ & $\begin{array}{l}-61.64 * * \\
(30.81)\end{array}$ \\
\hline $\begin{array}{l}\text { \# of qualifying farmers in network } \\
\text { (nonsavers) }\end{array}$ & & & $\begin{array}{l}64.73^{*} \\
(33.87)\end{array}$ & $\begin{array}{c}51.47 \\
(32.92)\end{array}$ \\
\hline Total network size & $\begin{array}{c}-7.49 \\
(17.26)\end{array}$ & $\begin{array}{c}-7.64 \\
(16.71)\end{array}$ & $\begin{array}{c}-6.76 \\
(17.06)\end{array}$ & $\begin{array}{c}-7.28 \\
(16.51)\end{array}$ \\
\hline Age (10 years) & & $\begin{array}{l}-0.82 \\
(5.89)\end{array}$ & & $\begin{array}{l}-0.85 \\
(5.82)\end{array}$ \\
\hline Education (years) & & $\begin{array}{c}0.55 \\
(1.79)\end{array}$ & & $\begin{array}{c}0.96 \\
(1.77)\end{array}$ \\
\hline Wealth index & & $\begin{array}{c}13.89 \\
(10.50)\end{array}$ & & $\begin{array}{c}13.72 \\
(10.40)\end{array}$ \\
\hline WTP 2011 (Rs. 100/hour) & & $\begin{array}{c}0.27^{* * *} \\
(0.05)\end{array}$ & & $\begin{array}{c}0.26 * * * \\
(0.05)\end{array}$ \\
\hline Constant & $\begin{array}{c}300.68 * * * \\
(10.99)\end{array}$ & $\begin{array}{c}254.81 * * * \\
(36.16)\end{array}$ & $\begin{array}{c}299.20 * * * \\
(10.87)\end{array}$ & $\begin{array}{c}252.45^{* * *} \\
(35.72)\end{array}$ \\
\hline Observations & 422 & 422 & 422 & 422 \\
\hline
\end{tabular}


Table C2-Network effects on demand at various prices

\begin{tabular}{|c|c|c|c|c|c|c|c|c|}
\hline Dependent variable: WTP 2012 & $\begin{array}{c}1(1) \\
\text { Rs.250 }\end{array}$ & $\begin{array}{c}(2) \\
\text { Rs.350 } \\
\end{array}$ & $\begin{array}{c}(3) \\
\text { Rs.500 } \\
\end{array}$ & $\begin{array}{c}(4) \\
\text { Rs. } 600 \\
\end{array}$ & $\begin{array}{c}5) \\
\text { Rs.250 }\end{array}$ & $\begin{array}{c}6) \\
\text { Rs.350 } \\
\end{array}$ & $\begin{array}{c}(7) \\
\text { Rs.500 }\end{array}$ & $\begin{array}{c}\text { (8) } \\
\text { Rs. } 600 \\
\end{array}$ \\
\hline \multirow[t]{2}{*}{ \# of adopters in network } & $0.16^{* *}$ & 0.13 & 0.05 & 0.03 & & & & \\
\hline & $(0.06)$ & $(0.08)$ & $(0.06)$ & $(0.05)$ & & & & \\
\hline \multirow[t]{3}{*}{ \# of adopters in network (water savers) } & & & & & $0.33 * * *$ & $0.26 * *$ & $0.21 * *$ & $0.17^{* *}$ \\
\hline & & & & & $(0.10)$ & $(0.13)$ & $(0.09)$ & $(0.08)$ \\
\hline & & & & & [0.009] & [0.152] & {$[0.010]$} & [0.019] \\
\hline \multirow[t]{2}{*}{ \# of adopters in network (nonsavers) } & & & & & -0.03 & 0.01 & -0.11 & -0.07 \\
\hline & & & & & $(0.09)$ & $(0.11)$ & $(0.08)$ & $(0.07)$ \\
\hline \multirow[t]{2}{*}{ \# of qualifying farmers in network } & -0.07 & 0.05 & -0.02 & -0.04 & & & & \\
\hline & $(0.06)$ & $(0.07)$ & $(0.05)$ & $(0.04)$ & & & & \\
\hline \multirow{2}{*}{$\begin{array}{l}\text { \# of qualifying farmers in network (water } \\
\text { savers) }\end{array}$} & & & & & $-0.18 * * *$ & -0.02 & $-0.10 *$ & -0.08 \\
\hline & & & & & $(0.07)$ & $(0.08)$ & $(0.06)$ & $(0.05)$ \\
\hline \multirow{2}{*}{$\begin{array}{l}\text { \# of qualifying farmers in network } \\
\text { (nonsavers) }\end{array}$} & & & & & 0.07 & 0.14 & 0.08 & 0.00 \\
\hline & & & & & $(0.07)$ & $(0.09)$ & $(0.06)$ & $(0.05)$ \\
\hline \multirow[t]{2}{*}{ Total network size } & -0.01 & -0.06 & 0.01 & 0.02 & -0.00 & -0.06 & 0.01 & 0.02 \\
\hline & $(0.04)$ & $(0.05)$ & $(0.03)$ & $(0.03)$ & $(0.04)$ & $(0.05)$ & $(0.03)$ & $(0.03)$ \\
\hline \multirow[t]{2}{*}{ Age (10 years) } & -0.00 & -0.01 & -0.00 & 0.00 & -0.00 & -0.01 & -0.00 & 0.00 \\
\hline & $(0.01)$ & $(0.02)$ & $(0.01)$ & $(0.01)$ & $(0.01)$ & $(0.02)$ & $(0.01)$ & $(0.01)$ \\
\hline \multirow[t]{2}{*}{ Education (years) } & 0.00 & 0.00 & -0.00 & -0.00 & 0.00 & 0.00 & -0.00 & -0.00 \\
\hline & $(0.00)$ & $(0.00)$ & $(0.00)$ & $(0.00)$ & $(0.00)$ & $(0.00)$ & $(0.00)$ & $(0.00)$ \\
\hline \multirow[t]{2}{*}{ Wealth index } & $0.05 * *$ & 0.01 & -0.00 & -0.00 & $0.06 * *$ & 0.01 & -0.00 & -0.00 \\
\hline & $(0.02)$ & $(0.03)$ & $(0.02)$ & $(0.02)$ & $(0.02)$ & $(0.03)$ & $(0.02)$ & $(0.02)$ \\
\hline \multirow[t]{2}{*}{ WTP 2011 (Rs. 100/hour) } & $0.04 * * *$ & $0.06 * * *$ & $0.04 * * *$ & $0.04 * * *$ & $0.03 * * *$ & $0.06 * * *$ & $0.04 * * *$ & $0.03 * * *$ \\
\hline & $(0.01)$ & $(0.01)$ & $(0.01)$ & $(0.01)$ & $(0.01)$ & $(0.01)$ & $(0.01)$ & $(0.01)$ \\
\hline \multirow[t]{2}{*}{ Constant } & $0.74 * * *$ & $0.40 * * *$ & 0.09 & 0.02 & $0.73 * * *$ & $0.40 * * *$ & 0.09 & 0.01 \\
\hline & $(0.08)$ & $(0.10)$ & $(0.07)$ & $(0.06)$ & $(0.08)$ & $(0.10)$ & $(0.07)$ & $(0.06)$ \\
\hline Observations & 422 & 422 & 422 & 422 & 422 & 422 & 422 & 422 \\
\hline
\end{tabular}

Notes: Water-saving denotes using 14 percent less water in 2011-2012 than in 2010-2011. IV model with lottery winning farmers instrumenting for farmers receiving leveling. Standard errors in parenthesis; ${ }^{* *} \mathrm{p}<0.01, * * \mathrm{p}<0.05, * \mathrm{p}<0.1$. P-values for difference between effect of water-saver and nonsaving network contacts are in brackets. 
Table C3-Network effects on mode of exposure to LLL

\begin{tabular}{|c|c|c|c|c|c|c|}
\hline \multirow[t]{2}{*}{ Exposure to LLL through... } & \multicolumn{2}{|c|}{$\begin{array}{l}\text {... conversation with } \\
\text { adopting farmer about LLL }\end{array}$} & \multicolumn{2}{|c|}{$\begin{array}{l}\text {...seeing LLL unit } \\
\text { operate }\end{array}$} & \multicolumn{2}{|c|}{$\begin{array}{l}\text {...observing field of } \\
\text { adopting farmer }\end{array}$} \\
\hline & $(1)$ & $(2)$ & (3) & (4) & (5) & (6) \\
\hline \multirow[t]{2}{*}{ \# of adopters in network } & 0.10 & & 0.09 & & 0.13 & \\
\hline & $(0.08)$ & & $(0.08)$ & & $(0.08)$ & \\
\hline \multirow{3}{*}{$\begin{array}{l}\text { \# of adopters in network } \\
\text { (water savers) }\end{array}$} & & 0.14 & & 0.05 & & 0.11 \\
\hline & & $(0.13)$ & & $(0.13)$ & & $(0.13)$ \\
\hline & & {$[0.752]$} & & [0.752] & & [0.602] \\
\hline \# of adopters in network & & 0.09 & & 0.11 & & $0.20^{*}$ \\
\hline (nonsavers) & & $(0.11)$ & & $(0.11)$ & & $(0.11)$ \\
\hline $\begin{array}{l}\text { \# of qualifying farmers in } \\
\text { network }\end{array}$ & $\begin{array}{l}-0.00 \\
(0.07)\end{array}$ & & $\begin{array}{l}-0.01 \\
(0.07)\end{array}$ & & $\begin{array}{c}-0.14 * * \\
(0.07)\end{array}$ & \\
\hline $\begin{array}{l}\text { \# of qualifying farmers in } \\
\text { network (water savers) }\end{array}$ & & $\begin{array}{c}0.01 \\
(0.08)\end{array}$ & & $\begin{array}{c}-0.02 \\
(0.09)\end{array}$ & & $\begin{array}{l}-0.07 \\
(0.09)\end{array}$ \\
\hline $\begin{array}{l}\text { \# of qualifying farmers in } \\
\text { network (nonsavers) }\end{array}$ & & $\begin{array}{l}-0.02 \\
(0.09)\end{array}$ & & $\begin{array}{l}-0.00 \\
(0.09)\end{array}$ & & $\begin{array}{c}-0.23 * * \\
(0.09)\end{array}$ \\
\hline Total network size & $\begin{array}{c}0.00 \\
(0.05)\end{array}$ & $\begin{array}{c}0.00 \\
(0.05)\end{array}$ & $\begin{array}{l}-0.01 \\
(0.05)\end{array}$ & $\begin{array}{l}-0.01 \\
(0.05)\end{array}$ & $\begin{array}{c}0.06 \\
(0.05)\end{array}$ & $\begin{array}{c}0.06 \\
(0.05)\end{array}$ \\
\hline Age (10 years) & $\begin{array}{c}0.04^{* * *} \\
(0.02)\end{array}$ & $\begin{array}{c}0.04 * * * \\
(0.02)\end{array}$ & $\begin{array}{l}-0.01 \\
(0.02)\end{array}$ & $\begin{array}{l}-0.01 \\
(0.02)\end{array}$ & $\begin{array}{c}0.02 \\
(0.02)\end{array}$ & $\begin{array}{c}0.02 \\
(0.02)\end{array}$ \\
\hline Education (years) & $\begin{array}{l}0.01^{* *} \\
(0.00)\end{array}$ & $\begin{array}{l}0.01 * * \\
(0.00)\end{array}$ & $\begin{array}{l}0.01^{* *} \\
(0.00)\end{array}$ & $\begin{array}{l}0.01 * * \\
(0.00)\end{array}$ & $\begin{array}{c}0.01 \\
(0.00)\end{array}$ & $\begin{array}{c}0.01 \\
(0.00)\end{array}$ \\
\hline Wealth index & $\begin{array}{l}-0.04 \\
(0.03)\end{array}$ & $\begin{array}{l}-0.04 \\
(0.03)\end{array}$ & $\begin{array}{l}-0.02 \\
(0.03)\end{array}$ & $\begin{array}{l}-0.02 \\
(0.03)\end{array}$ & $\begin{array}{l}-0.05^{*} \\
(0.03)\end{array}$ & $\begin{array}{l}-0.06^{*} \\
(0.03)\end{array}$ \\
\hline Constant & $\begin{array}{c}0.30^{* * *} \\
(0.10)\end{array}$ & $\begin{array}{c}0.30^{* * *} \\
(0.10)\end{array}$ & $\begin{array}{c}0.54^{* * *} \\
(0.10)\end{array}$ & $\begin{array}{c}0.54^{* * *} \\
(0.10)\end{array}$ & $\begin{array}{c}0.34 * * * \\
(0.10)\end{array}$ & $\begin{array}{c}0.34 * * * \\
(0.10)\end{array}$ \\
\hline Observations & 422 & 422 & 422 & 422 & 422 & 422 \\
\hline
\end{tabular}

Notes: Water-saving denotes using 14 percent less water in 2011-2012 than in 2010-2011. IV linear probability model with lottery winning farmers instrumenting for farmers receiving leveling. Standard errors in parenthesis; $* * * p<0.01, * * p<0.05, * p<0.1$. P-values for difference between effect of water-saver and nonsaving network contacts are in brackets. 
Table C4-Placebo test for spurious network effects

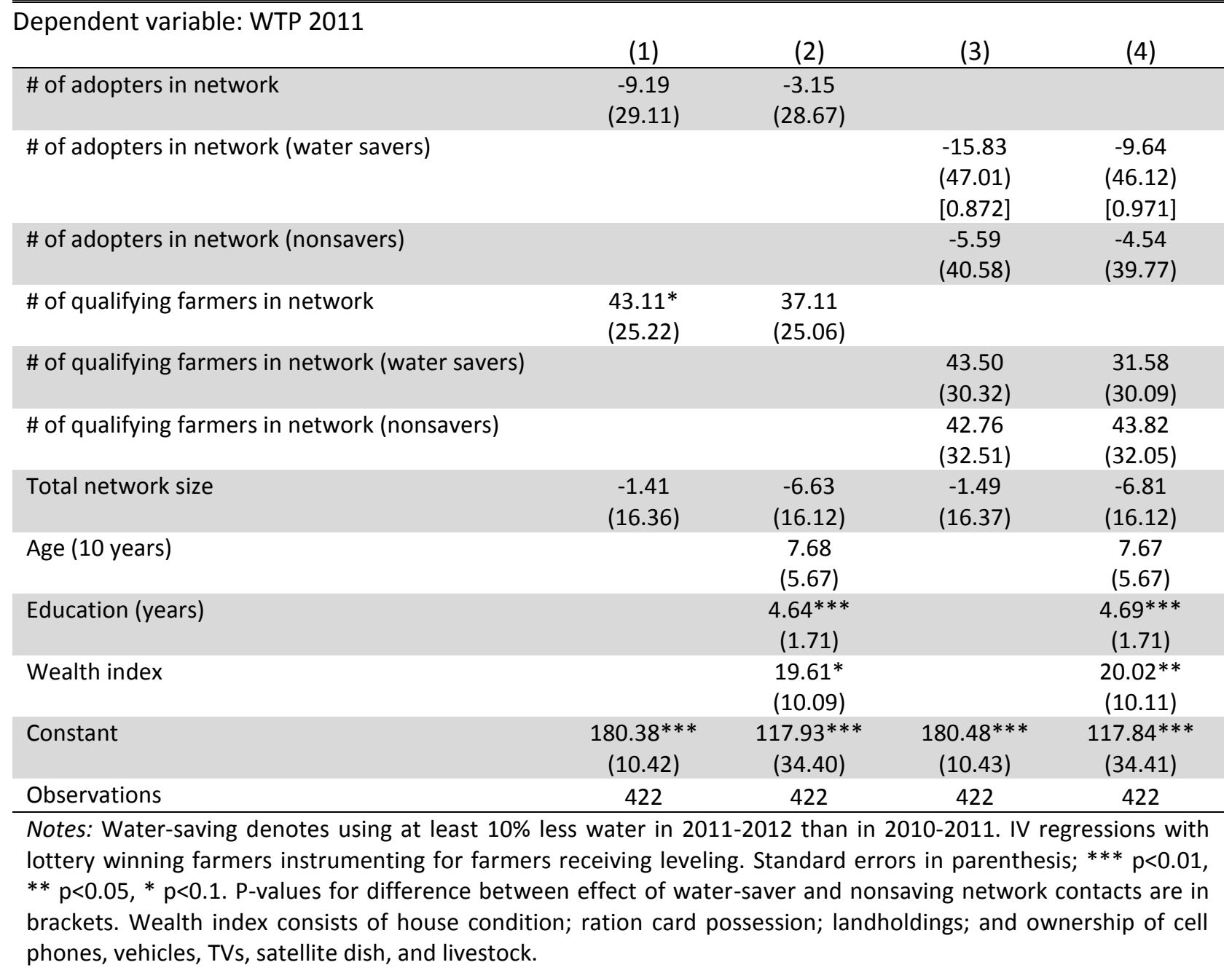


Table C5-Network effects using alternate network types

\begin{tabular}{|c|c|c|c|c|c|c|}
\hline \multirow[t]{2}{*}{$\begin{array}{l}\text { Dependent variable: } \\
\text { WTP } 2012\end{array}$} & \multicolumn{2}{|c|}{$\begin{array}{l}\text { Friends and family } \\
(\mathrm{FF}) \text {, unidirectional }\end{array}$} & \multicolumn{2}{|c|}{$\begin{array}{l}\text { Friends and family } \\
\text { (FF), bidirectional }\end{array}$} & \multicolumn{2}{|c|}{$\begin{array}{l}\text { Agricultural contacts, } \\
\text { bidirectional }\end{array}$} \\
\hline & (1) & $(2)$ & (3) & $(4)$ & $(5)$ & (6) \\
\hline \# of adopters in network & $\begin{array}{l}10.73 \\
(25.07)\end{array}$ & & $\begin{array}{l}14.24 \\
(19.94)\end{array}$ & & $\begin{array}{c}36.78 \\
(24.42)\end{array}$ & \\
\hline $\begin{array}{l}\text { \# of adopters in network } \\
\text { (water savers) }\end{array}$ & & $\begin{array}{l}27.97 \\
(34.03) \\
{[0.202]}\end{array}$ & & $\begin{array}{c}28.96 \\
(25.66) \\
{[0.387]}\end{array}$ & & $\begin{array}{l}65.84^{*} \\
(34.46) \\
{[0.066]}\end{array}$ \\
\hline $\begin{array}{l}\text { \# of adopters in network } \\
\text { (nonsavers) }\end{array}$ & & $\begin{array}{l}-28.42 \\
(32.94)\end{array}$ & & $\begin{array}{l}-16.04 \\
(26.70)\end{array}$ & & $\begin{array}{c}-7.23 \\
(28.84)\end{array}$ \\
\hline $\begin{array}{l}\text { \# of qualifying farmers in } \\
\text { network }\end{array}$ & $\begin{array}{c}4.38 \\
(20.57)\end{array}$ & & $\begin{array}{c}1.12 \\
(13.96)\end{array}$ & & $\begin{array}{c}8.86 \\
(17.61)\end{array}$ & \\
\hline $\begin{array}{l}\text { \# of qualifying farmers in } \\
\text { network (water savers) }\end{array}$ & & $\begin{array}{l}-22.77 \\
(23.84)\end{array}$ & & $\begin{array}{l}-18.15 \\
(16.85)\end{array}$ & & $\begin{array}{l}-13.17 \\
(20.87)\end{array}$ \\
\hline $\begin{array}{l}\text { \# of qualifying farmers in } \\
\text { network (nonsavers) }\end{array}$ & & $\begin{array}{l}48.85^{*} \\
(26.99)\end{array}$ & & $\begin{array}{c}25.85 \\
(17.72)\end{array}$ & & $\begin{array}{l}40.46^{*} \\
(21.72)\end{array}$ \\
\hline Total network size & $\begin{array}{l}-6.36 \\
(8.89)\end{array}$ & $\begin{array}{l}-8.00 \\
(8.87)\end{array}$ & $\begin{array}{l}-5.02 \\
(7.03)\end{array}$ & $\begin{array}{l}-4.98 \\
(6.99)\end{array}$ & $\begin{array}{c}-8.18 \\
(10.42)\end{array}$ & $\begin{array}{c}-7.36 \\
(10.38)\end{array}$ \\
\hline Age (10 years) & $\begin{array}{l}-0.30 \\
(5.89)\end{array}$ & $\begin{array}{l}-0.72 \\
(5.83)\end{array}$ & $\begin{array}{l}-0.35 \\
(5.89)\end{array}$ & $\begin{array}{l}-0.88 \\
(5.86)\end{array}$ & $\begin{array}{l}-1.32 \\
(5.88)\end{array}$ & $\begin{array}{l}-1.61 \\
(5.85)\end{array}$ \\
\hline Education (years) & $\begin{array}{c}0.58 \\
(1.80)\end{array}$ & $\begin{array}{c}0.75 \\
(1.79)\end{array}$ & $\begin{array}{c}0.53 \\
(1.81)\end{array}$ & $\begin{array}{c}0.56 \\
(1.80)\end{array}$ & $\begin{array}{c}0.22 \\
(1.78)\end{array}$ & $\begin{array}{c}0.13 \\
(1.77)\end{array}$ \\
\hline Wealth index & $\begin{array}{c}12.81 \\
(10.48)\end{array}$ & $\begin{array}{c}12.20 \\
(10.38)\end{array}$ & $\begin{array}{c}13.12 \\
(10.52)\end{array}$ & $\begin{array}{c}13.58 \\
(10.46)\end{array}$ & $\begin{array}{c}9.63 \\
(10.82)\end{array}$ & $\begin{array}{c}10.27 \\
(10.79)\end{array}$ \\
\hline WTP 2011 (Rs. 100/hour) & $\begin{array}{c}0.27^{* * *} \\
(0.05)\end{array}$ & $\begin{array}{c}0.27^{* * *} \\
(0.05)\end{array}$ & $\begin{array}{c}0.27^{* * *} \\
(0.05)\end{array}$ & $\begin{array}{c}0.27^{* * *} \\
(0.05)\end{array}$ & $\begin{array}{c}0.26^{* * *} \\
(0.05)\end{array}$ & $\begin{array}{c}0.25^{* * *} \\
(0.05)\end{array}$ \\
\hline Constant & $\begin{array}{c}255.39 * * * \\
(35.81)\end{array}$ & $\begin{array}{c}256.55^{* * *} \\
(35.48)\end{array}$ & $\begin{array}{c}256.38^{* * *} \\
(35.92)\end{array}$ & $\begin{array}{c}258.82^{* * *} \\
(35.74)\end{array}$ & $\begin{array}{c}251.96 * * * \\
(35.70)\end{array}$ & $\begin{array}{c}253.74^{* * *} \\
(35.49)\end{array}$ \\
\hline Observations & 422 & 422 & 422 & 422 & 422 & 422 \\
\hline
\end{tabular}




\section{Appendix D: Intent to treat estimates}

Table D1-Network effects on demand for LLL

\begin{tabular}{|c|c|c|c|c|}
\hline Dependent variable: WTP 2012 & $(1)$ & $(2)$ & (3) & (4) \\
\hline At least one adopter in network & $\begin{array}{l}78.33^{* *} \\
(31.81)\end{array}$ & $\begin{array}{l}78.21^{* *} \\
(30.99)\end{array}$ & & \\
\hline $\begin{array}{l}\text { At least one adopter in network } \\
\text { (water savers) }\end{array}$ & & & $\begin{array}{c}126.70 * * * \\
(41.76) \\
{[0.038]}\end{array}$ & $\begin{array}{c}134.45^{* * *} \\
(40.44) \\
{[0.012]}\end{array}$ \\
\hline $\begin{array}{l}\text { At least one adopter in network } \\
\text { (nonsavers) }\end{array}$ & & & $\begin{array}{c}2.16 \\
(41.94)\end{array}$ & $\begin{array}{l}-10.51 \\
(40.49)\end{array}$ \\
\hline One qualifying farmer in network & $\begin{array}{c}19.24 \\
(32.16)\end{array}$ & $\begin{array}{c}8.94 \\
(31.22)\end{array}$ & & \\
\hline Two qualifying farmers in network & $\begin{array}{l}-11.37 \\
(59.21)\end{array}$ & $\begin{array}{l}-55.68 \\
(58.23)\end{array}$ & & \\
\hline Three qualifying farmers in network & $\begin{array}{l}-21.16 \\
(93.25)\end{array}$ & $\begin{array}{l}-55.07 \\
(92.02)\end{array}$ & & \\
\hline Four qualifying farmers in network & $\begin{array}{c}295.25 \\
(234.30)\end{array}$ & $\begin{array}{c}210.70 \\
(227.99)\end{array}$ & & \\
\hline $\begin{array}{l}\text { One qualifying farmer in network } \\
\text { (water savers) }\end{array}$ & & & $\begin{array}{l}-19.73 \\
(36.96)\end{array}$ & $\begin{array}{l}-37.38 \\
(35.87)\end{array}$ \\
\hline $\begin{array}{l}\text { Two qualifying farmers in network } \\
\text { (water savers) }\end{array}$ & & & $\begin{array}{c}-132.79 * \\
(77.84)\end{array}$ & $\begin{array}{c}-183.09 * * \\
(76.85)\end{array}$ \\
\hline $\begin{array}{l}\text { Three qualifying farmers in network } \\
\text { (water-savers) }\end{array}$ & & & $\begin{array}{c}-96.32 \\
(217.78)\end{array}$ & $\begin{array}{l}-178.95 \\
(211.45)\end{array}$ \\
\hline $\begin{array}{l}\text { One qualifying farmer in network } \\
\text { (nonsavers) }\end{array}$ & & & $\begin{array}{c}60.38 \\
(37.24)\end{array}$ & $\begin{array}{c}46.42 \\
(36.06)\end{array}$ \\
\hline $\begin{array}{l}\text { Two qualifying farmers in network } \\
\text { (water-savers) }\end{array}$ & & & $\begin{array}{c}29.72 \\
(78.88)\end{array}$ & $\begin{array}{c}23.98 \\
(76.38)\end{array}$ \\
\hline $\begin{array}{l}\text { Three qualifying farmers in network } \\
\text { (water-savers) }\end{array}$ & & & $\begin{array}{c}15.26 \\
(194.82)\end{array}$ & $\begin{array}{c}75.10 \\
(189.18)\end{array}$ \\
\hline $\begin{array}{l}\text { Four qualifying farmers in network } \\
\text { (water-savers) }\end{array}$ & & & $\begin{array}{c}336.87 \\
(238.86)\end{array}$ & $\begin{array}{c}267.99 \\
(231.99)\end{array}$ \\
\hline Total network size & $\begin{array}{c}-8.69 \\
(18.17)\end{array}$ & $\begin{array}{c}-7.11 \\
(17.71)\end{array}$ & $\begin{array}{c}-4.32 \\
(18.87)\end{array}$ & $\begin{array}{c}-3.29 \\
(18.38)\end{array}$ \\
\hline Age (10 years) & & $\begin{array}{l}-3.14 \\
(6.02)\end{array}$ & & $\begin{array}{l}-2.54 \\
(5.93)\end{array}$ \\
\hline Education (years) & & $\begin{array}{c}0.61 \\
(1.79)\end{array}$ & & $\begin{array}{c}0.83 \\
(1.78)\end{array}$ \\
\hline Wealth index & & $\begin{array}{c}14.27 \\
(10.50)\end{array}$ & & $\begin{array}{c}14.43 \\
(10.51)\end{array}$ \\
\hline WTP 2011 (Rs. 100/hour) & & $\begin{array}{c}0.27^{* * *} \\
(0.05)\end{array}$ & & $\begin{array}{c}0.27^{* * *} \\
(0.05)\end{array}$ \\
\hline Constant & $\begin{array}{c}295.96 * * * \\
(11.61)\end{array}$ & $\begin{array}{c}260.27^{* * *} \\
(36.25)\end{array}$ & $\begin{array}{c}295.54 * * * \\
(11.41)\end{array}$ & $\begin{array}{c}256.89 * * * \\
(36.03)\end{array}$ \\
\hline Observations & 422 & 422 & 422 & 422 \\
\hline R-squared & 0.03 & 0.11 & 0.05 & 0.13 \\
\hline
\end{tabular}

Notes: Water-saving denotes using 14 percent less water in 2011-2012 than in 2010-2011. OLS regressions. Standard errors in parenthesis; ${ }^{* * *} \mathrm{p}<0.01,{ }^{*} \mathrm{p}<0.05, * \mathrm{p}<0.1$. P-values for difference between effect of water-saver and nonsaving network contacts are in brackets. 
Table D2-Network effects on demand at various prices

\begin{tabular}{|c|c|c|c|c|c|c|c|c|c|c|}
\hline Dependent variable: WTP 2012 & $\begin{array}{c}1(1) \\
\text { Rs.250 }\end{array}$ & $\begin{array}{c}\text { (2) } \\
\text { Rs.350 }\end{array}$ & $\begin{array}{c}1(3) \\
\text { Rs.500 } \\
\end{array}$ & $\begin{array}{c}(4) \\
\text { Rs. } 600 \\
\end{array}$ & $\begin{array}{c}\text { (5) } \\
\text { Adoption }\end{array}$ & $\begin{array}{c}16) \\
\text { Rs. } 250 \\
\end{array}$ & $\begin{array}{c}17) \\
\text { Rs.350 }\end{array}$ & $\begin{array}{c}18) \\
\text { Rs.500 } \\
\end{array}$ & $\begin{array}{c}\text { (9) } \\
\text { Rs. } 600 \\
\end{array}$ & $\begin{array}{c}\text { (10) } \\
\text { Adoption }\end{array}$ \\
\hline At least one adopter in network & $\begin{array}{l}0.15^{* *} \\
(0.07)\end{array}$ & $\begin{array}{l}0.22 * * \\
(0.09)\end{array}$ & $\begin{array}{c}0.08 \\
(0.06)\end{array}$ & $\begin{array}{c}0.05 \\
(0.05)\end{array}$ & $\begin{array}{c}0.14 * * \\
(0.06)\end{array}$ & & & & & \\
\hline At least one adopter in network (water savers) & & & & & & $\begin{array}{c}0.25 * * * \\
(0.09) \\
{[0.027]}\end{array}$ & $\begin{array}{c}0.24 * * \\
(0.11) \\
{[0.406]}\end{array}$ & $\begin{array}{c}0.18 * * \\
(0.08) \\
{[0.049]}\end{array}$ & $\begin{array}{c}0.15 * * \\
(0.07) \\
{[0.029]}\end{array}$ & $\begin{array}{c}0.10 \\
(0.09) \\
{[0.657]}\end{array}$ \\
\hline At least one adopter in network (nonsavers) & & & & & & $\begin{array}{l}-0.03 \\
(0.09)\end{array}$ & $\begin{array}{c}0.11 \\
(0.11)\end{array}$ & $\begin{array}{l}-0.04 \\
(0.08)\end{array}$ & $\begin{array}{l}-0.06 \\
(0.07)\end{array}$ & $\begin{array}{c}0.04 \\
(0.09)\end{array}$ \\
\hline $\begin{array}{l}\text { Controls for number of qualifying farmers in } \\
\text { network }\end{array}$ & Yes & Yes & Yes & Yes & Yes & & & & & \\
\hline $\begin{array}{l}\text { Controls for number of qualifying water saving } \\
\text { farmers in network }\end{array}$ & & & & & & Yes & Yes & Yes & Yes & Yes \\
\hline $\begin{array}{l}\text { Controls for number of qualifying nonsaving } \\
\text { farmers in network }\end{array}$ & & & & & & Yes & Yes & Yes & Yes & Yes \\
\hline Total network size & $\begin{array}{c}0.01 \\
(0.04)\end{array}$ & $\begin{array}{l}-0.05 \\
(0.05)\end{array}$ & $\begin{array}{l}-0.00 \\
(0.03)\end{array}$ & $\begin{array}{c}0.00 \\
(0.03)\end{array}$ & $\begin{array}{l}-0.04 \\
(0.04)\end{array}$ & $\begin{array}{c}0.01 \\
(0.04)\end{array}$ & $\begin{array}{l}-0.04 \\
(0.05)\end{array}$ & $\begin{array}{c}0.00 \\
(0.04)\end{array}$ & $\begin{array}{c}0.01 \\
(0.03)\end{array}$ & $\begin{array}{l}-0.05 \\
(0.04)\end{array}$ \\
\hline Age (10 years) & $\begin{array}{l}-0.00 \\
(0.01)\end{array}$ & $\begin{array}{l}-0.01 \\
(0.02)\end{array}$ & $\begin{array}{l}-0.01 \\
(0.01)\end{array}$ & $\begin{array}{l}-0.00 \\
(0.01)\end{array}$ & $\begin{array}{c}0.00 \\
(0.01)\end{array}$ & $\begin{array}{l}-0.00 \\
(0.01)\end{array}$ & $\begin{array}{l}-0.01 \\
(0.02)\end{array}$ & $\begin{array}{l}-0.01 \\
(0.01)\end{array}$ & $\begin{array}{c}0.00 \\
(0.01)\end{array}$ & $\begin{array}{c}0.01 \\
(0.01)\end{array}$ \\
\hline Education (years) & $\begin{array}{c}0.00 \\
(0.00)\end{array}$ & $\begin{array}{c}0.00 \\
(0.00)\end{array}$ & $\begin{array}{l}-0.00 \\
(0.00)\end{array}$ & $\begin{array}{l}-0.00 \\
(0.00)\end{array}$ & $\begin{array}{c}0.01^{* *} \\
(0.00)\end{array}$ & $\begin{array}{c}0.00 \\
(0.00)\end{array}$ & $\begin{array}{c}0.00 \\
(0.00)\end{array}$ & $\begin{array}{l}-0.00 \\
(0.00)\end{array}$ & $\begin{array}{l}-0.00 \\
(0.00)\end{array}$ & $\begin{array}{c}0.01 * * \\
(0.00)\end{array}$ \\
\hline Wealth index & $\begin{array}{c}0.05^{* *} \\
(0.02)\end{array}$ & $\begin{array}{c}0.01 \\
(0.03)\end{array}$ & $\begin{array}{c}-0.00 \\
(0.02)\end{array}$ & $\begin{array}{c}-0.00 \\
(0.02)\end{array}$ & $\begin{array}{l}-0.01 \\
(0.02)\end{array}$ & $\begin{array}{c}0.06 * * \\
(0.02)\end{array}$ & $\begin{array}{c}0.01 \\
(0.03)\end{array}$ & $\begin{array}{l}-0.00 \\
(0.02)\end{array}$ & $\begin{array}{c}-0.00 \\
(0.02)\end{array}$ & $\begin{array}{l}-0.01 \\
(0.02)\end{array}$ \\
\hline WTP 2011 (Rs. 100/hour) & $\begin{array}{c}0.04 * * * \\
(0.01)\end{array}$ & $\begin{array}{c}0.06 * * * \\
(0.01)\end{array}$ & $\begin{array}{c}0.04 * * * \\
(0.01)\end{array}$ & $\begin{array}{c}0.03 * * * \\
(0.01)\end{array}$ & $\begin{array}{c}0.02 * * \\
(0.01)\end{array}$ & $\begin{array}{c}0.04 * * * \\
(0.01)\end{array}$ & $\begin{array}{c}0.06 * * * \\
(0.01)\end{array}$ & $\begin{array}{c}0.04^{* * *} \\
(0.01)\end{array}$ & $\begin{array}{c}0.04 * * * \\
(0.01)\end{array}$ & $\begin{array}{c}0.02 * * \\
(0.01)\end{array}$ \\
\hline Constant & $\begin{array}{c}0.74 * * * \\
(0.08)\end{array}$ & $\begin{array}{c}0.42 * * * \\
(0.10)\end{array}$ & $\begin{array}{c}0.10 \\
(0.07)\end{array}$ & $\begin{array}{c}0.02 \\
(0.06)\end{array}$ & $\begin{array}{c}0.05 \\
(0.08)\end{array}$ & $\begin{array}{c}0.74 * * * \\
(0.08)\end{array}$ & $\begin{array}{c}0.42 * * * \\
(0.10)\end{array}$ & $\begin{array}{c}0.09 \\
(0.07)\end{array}$ & $\begin{array}{c}0.02 \\
(0.06)\end{array}$ & $\begin{array}{c}0.04 \\
(0.08)\end{array}$ \\
\hline Observations & 422 & 422 & 422 & 422 & 422 & 422 & 422 & 422 & 422 & 422 \\
\hline R-squared & 0.07 & 0.08 & 0.06 & 0.07 & 0.04 & 0.09 & 0.09 & 0.06 & 0.09 & 0.04 \\
\hline
\end{tabular}

Notes: Water-saving denotes using 14 percent less water in 2011-2012 than in 2010-2011. OLS regressions. Standard errors in parenthesis; $* * * p<0.01, * *$ $\mathrm{p}<0.05, * \mathrm{p}<0.1$. P-values for difference between effect of water-saver and nonsaving network contacts are in brackets. 
Table D3-Network effects on mode of exposure to LLL

\begin{tabular}{|c|c|c|c|c|c|c|}
\hline \multirow[t]{2}{*}{ Exposure to LLL through... } & \multicolumn{2}{|c|}{$\begin{array}{l}\text {... conversation with } \\
\text { adopting farmer about LLL }\end{array}$} & \multicolumn{2}{|c|}{$\begin{array}{l}\text {...seeing LLL unit } \\
\text { operate }\end{array}$} & \multicolumn{2}{|c|}{$\begin{array}{l}\text {...observing field of } \\
\text { adopting farmer }\end{array}$} \\
\hline & $(1)$ & $(2)$ & (3) & $(4)$ & (5) & (6) \\
\hline $\begin{array}{l}\text { At least one adopter in } \\
\text { network }\end{array}$ & $\begin{array}{l}0.14^{*} \\
(0.08)\end{array}$ & & $\begin{array}{c}0.06 \\
(0.09)\end{array}$ & & $\begin{array}{c}0.23^{* * *} \\
(0.09)\end{array}$ & \\
\hline $\begin{array}{l}\text { At least one adopter in } \\
\text { network (water savers) }\end{array}$ & & $\begin{array}{c}0.10 \\
(0.11) \\
{[0.953]}\end{array}$ & & $\begin{array}{c}0.02 \\
(0.11) \\
{[0.893]}\end{array}$ & & $\begin{array}{c}0.08 \\
(0.12) \\
{[0.366]}\end{array}$ \\
\hline $\begin{array}{l}\text { At least one adopter in } \\
\text { network (nonsavers) }\end{array}$ & & $\begin{array}{c}0.10 \\
(0.11)\end{array}$ & & $\begin{array}{c}0.04 \\
(0.11)\end{array}$ & & $\begin{array}{l}0.23^{*} \\
(0.12)\end{array}$ \\
\hline $\begin{array}{l}\text { One qualifying farmer in } \\
\text { network }\end{array}$ & $\begin{array}{l}-0.01 \\
(0.09)\end{array}$ & & $\begin{array}{l}-0.01 \\
(0.09)\end{array}$ & & $\begin{array}{c}-0.31 * * * \\
(0.09)\end{array}$ & \\
\hline $\begin{array}{l}\text { Two qualifying farmers in } \\
\text { network }\end{array}$ & $\begin{array}{l}-0.16 \\
(0.16)\end{array}$ & & $\begin{array}{l}-0.05 \\
(0.16)\end{array}$ & & $\begin{array}{l}-0.29 * \\
(0.16)\end{array}$ & \\
\hline $\begin{array}{l}\text { Three qualifying farmers in } \\
\text { network }\end{array}$ & $\begin{array}{c}0.04 \\
(0.25)\end{array}$ & & $\begin{array}{c}0.18 \\
(0.25)\end{array}$ & & $\begin{array}{l}-0.54^{* *} \\
(0.25)\end{array}$ & \\
\hline $\begin{array}{l}\text { Four qualifying farmers in } \\
\text { network }\end{array}$ & $\begin{array}{c}0.24 \\
(0.62)\end{array}$ & & $\begin{array}{c}0.47 \\
(0.64)\end{array}$ & & $\begin{array}{l}-1.32^{* *} \\
(0.64)\end{array}$ & \\
\hline $\begin{array}{l}\text { One qualifying farmer in } \\
\text { network (water savers) }\end{array}$ & & $\begin{array}{c}0.04 \\
(0.10)\end{array}$ & & $\begin{array}{c}0.01 \\
(0.10)\end{array}$ & & $\begin{array}{l}-0.13 \\
(0.10)\end{array}$ \\
\hline $\begin{array}{l}\text { Two qualifying farmers in } \\
\text { network (water savers) }\end{array}$ & & $\begin{array}{l}-0.04 \\
(0.21)\end{array}$ & & $\begin{array}{l}-0.09 \\
(0.21)\end{array}$ & & $\begin{array}{l}-0.17 \\
(0.22)\end{array}$ \\
\hline $\begin{array}{l}\text { Three qualifying farmers in } \\
\text { network (water savers) }\end{array}$ & & $\begin{array}{c}0.38 \\
(0.58)\end{array}$ & & $\begin{array}{c}0.48 \\
(0.60)\end{array}$ & & $\begin{array}{c}0.03 \\
(0.60)\end{array}$ \\
\hline $\begin{array}{l}\text { One qualifying farmer in } \\
\text { network (nonsavers) }\end{array}$ & & $\begin{array}{l}-0.04 \\
(0.10)\end{array}$ & & $\begin{array}{c}0.04 \\
(0.10)\end{array}$ & & $\begin{array}{c}-0.29 * * * \\
(0.10)\end{array}$ \\
\hline $\begin{array}{l}\text { Two qualifying farmers in } \\
\text { network (water-savers) }\end{array}$ & & $\begin{array}{c}0.04 \\
(0.21)\end{array}$ & & $\begin{array}{c}0.06 \\
(0.22)\end{array}$ & & $\begin{array}{l}-0.35 \\
(0.22)\end{array}$ \\
\hline $\begin{array}{l}\text { Three qualifying farmers in } \\
\text { network (water-savers) }\end{array}$ & & $\begin{array}{l}-0.55 \\
(0.52)\end{array}$ & & $\begin{array}{c}0.46 \\
(0.53)\end{array}$ & & $\begin{array}{l}-0.88 \\
(0.54)\end{array}$ \\
\hline $\begin{array}{l}\text { Four qualifying farmers in } \\
\text { network (water-savers) }\end{array}$ & & $\begin{array}{l}0.42 \\
(0.64)\end{array}$ & & $\begin{array}{c}0.55 \\
(0.65)\end{array}$ & & $\begin{array}{l}-1.25^{*} \\
(0.66)\end{array}$ \\
\hline Total network size & $\begin{array}{c}0.01 \\
(0.05)\end{array}$ & $\begin{array}{l}-0.01 \\
(0.05)\end{array}$ & $\begin{array}{l}-0.02 \\
(0.05)\end{array}$ & $\begin{array}{l}-0.02 \\
(0.05)\end{array}$ & $\begin{array}{c}0.08 \\
(0.05)\end{array}$ & $\begin{array}{c}0.07 \\
(0.05)\end{array}$ \\
\hline Age (10 years) & $\begin{array}{l}0.04 * * \\
(0.02)\end{array}$ & $\begin{array}{l}0.04 * * \\
(0.02)\end{array}$ & $\begin{array}{l}-0.01 \\
(0.02)\end{array}$ & $\begin{array}{l}-0.01 \\
(0.02)\end{array}$ & $\begin{array}{c}0.02 \\
(0.02)\end{array}$ & $\begin{array}{c}0.01 \\
(0.02)\end{array}$ \\
\hline Education (years) & $\begin{array}{l}0.01 * * \\
(0.00)\end{array}$ & $\begin{array}{l}0.01^{* *} \\
(0.00)\end{array}$ & $\begin{array}{c}0.01^{* *} \\
(0.00)\end{array}$ & $\begin{array}{l}0.01^{* *} \\
(0.00)\end{array}$ & $\begin{array}{c}0.00 \\
(0.00)\end{array}$ & $\begin{array}{c}0.00 \\
(0.00)\end{array}$ \\
\hline Constant & $\begin{array}{c}0.34^{* * *} \\
(0.09)\end{array}$ & $\begin{array}{c}0.34^{* * *} \\
(0.09)\end{array}$ & $\begin{array}{c}0.55^{* * *} \\
(0.10)\end{array}$ & $\begin{array}{c}0.54^{* * *} \\
(0.10)\end{array}$ & $\begin{array}{c}0.39 * * * \\
(0.10)\end{array}$ & $\begin{array}{c}0.40^{* * *} \\
(0.10)\end{array}$ \\
\hline Observations & 422 & 422 & 422 & 422 & 422 & 422 \\
\hline R-squared & 0.04 & 0.04 & 0.02 & 0.02 & 0.04 & 0.03 \\
\hline
\end{tabular}

Notes: Water-saving denotes using 14 percent less water in 2011-2012 than in 2010-2011. OLS regressions. Standard errors in parenthesis; ${ }^{* *} p<0.01,{ }^{* *} p<0.05,{ }^{*} p<0.1$. P-values for difference between effect of watersaver and nonsaving network contacts are in brackets. 
Table D4-Placebo test for spurious network effects

\begin{tabular}{|c|c|c|c|c|}
\hline Dependent variable: WTP 2011 & $(1)$ & $(2)$ & (3) & (4) \\
\hline At least one adopter in network & $\begin{array}{c}23.19 \\
(30.38)\end{array}$ & $\begin{array}{c}30.08 \\
(30.08)\end{array}$ & & \\
\hline At least one adopter in network (water-savers) & & & $\begin{array}{c}-17.45 \\
(40.16) \\
{[0.324]}\end{array}$ & $\begin{array}{l}-15.19 \\
(39.68) \\
{[0.658]}\end{array}$ \\
\hline At least one adopter in network (nonsavers) & & & $\begin{array}{c}39.24 \\
(40.32)\end{array}$ & $\begin{array}{c}33.25 \\
(39.70)\end{array}$ \\
\hline One qualifying farmer in network & $\begin{array}{c}19.97 \\
(30.71)\end{array}$ & $\begin{array}{c}12.29 \\
(30.34)\end{array}$ & & \\
\hline Two qualifying farmers in network & $\begin{array}{l}110.74 * \\
(56.55)\end{array}$ & $\begin{array}{l}98.10^{*} \\
(56.39)\end{array}$ & & \\
\hline Three qualifying farmers in network & $\begin{array}{c}36.35 \\
(89.05)\end{array}$ & $\begin{array}{c}26.33 \\
(89.44)\end{array}$ & & \\
\hline Four qualifying farmers in network & $\begin{array}{c}238.89 \\
(223.75)\end{array}$ & $\begin{array}{c}262.22 \\
(221.24)\end{array}$ & & \\
\hline One qualifying farmer in network (water savers) & & & $\begin{array}{c}45.82 \\
(35.54)\end{array}$ & $\begin{array}{c}40.85 \\
(35.14)\end{array}$ \\
\hline Two qualifying farmers in network (water savers) & & & $\begin{array}{c}88.11 \\
(74.84)\end{array}$ & $\begin{array}{c}56.52 \\
(75.35)\end{array}$ \\
\hline $\begin{array}{l}\text { Three qualifying farmers in network (water- } \\
\text { savers) }\end{array}$ & & & $\begin{array}{c}217.86 \\
(209.40)\end{array}$ & $\begin{array}{c}215.35 \\
(207.21)\end{array}$ \\
\hline One qualifying farmer in network (nonsavers) & & & $\begin{array}{c}43.08 \\
(35.80)\end{array}$ & $\begin{array}{c}43.26 \\
(35.31)\end{array}$ \\
\hline Two qualifying farmers in network (water-savers) & & & $\begin{array}{c}25.69 \\
(75.84)\end{array}$ & $\begin{array}{c}43.52 \\
(74.92)\end{array}$ \\
\hline $\begin{array}{l}\text { Three qualifying farmers in network (water- } \\
\text { savers) }\end{array}$ & & & $\begin{array}{l}-203.75 \\
(187.32)\end{array}$ & $\begin{array}{l}-147.80 \\
(185.49)\end{array}$ \\
\hline Four qualifying farmers in network (water-savers) & & & $\begin{array}{c}221.12 \\
(229.67)\end{array}$ & $\begin{array}{c}260.23 \\
(227.28)\end{array}$ \\
\hline Total network size & $\begin{array}{c}-5.57 \\
(17.35)\end{array}$ & $\begin{array}{l}-11.74 \\
(17.21)\end{array}$ & $\begin{array}{c}-4.98 \\
(18.14)\end{array}$ & $\begin{array}{l}-11.43 \\
(18.02)\end{array}$ \\
\hline Age (years) & & $\begin{array}{c}7.74 \\
(5.84)\end{array}$ & & $\begin{array}{c}7.06 \\
(5.81)\end{array}$ \\
\hline Education (years) & & $\begin{array}{c}4.55^{* * *} \\
(1.73)\end{array}$ & & $\begin{array}{c}4.64 * * * \\
(1.73)\end{array}$ \\
\hline Wealth index & & $\begin{array}{c}20.99 * * \\
(10.15)\end{array}$ & & $\begin{array}{l}19.19 * \\
(10.27)\end{array}$ \\
\hline Constant & $\begin{array}{c}182.50 * * * \\
(11.08)\end{array}$ & $\begin{array}{c}121.00 * * * \\
(34.72)\end{array}$ & $\begin{array}{c}179.44 * * * \\
(10.97)\end{array}$ & $\begin{array}{c}120.52 * * * \\
(34.85)\end{array}$ \\
\hline Observations & 422 & 422 & 422 & 422 \\
\hline R-squared & 0.04 & 0.08 & 0.04 & 0.08 \\
\hline
\end{tabular}

Notes: Water-saving denotes using at least $10 \%$ less water in 2011-2012 than in 2010-2011. OLS regressions. Standard errors in parenthesis; $* * * \mathrm{p}<0.01, * * \mathrm{p}<0.05, * \mathrm{p}<0.1$. P-values for difference between effect of watersaver and nonsaving network contacts are in brackets. Wealth index consists of house condition; ration card possession; landholdings; and ownership of cell phones, vehicles, TVs, satellite dish, and livestock. 
Table D5-Network effects using alternate network types

\begin{tabular}{|c|c|c|c|c|c|c|}
\hline \multirow[t]{2}{*}{$\begin{array}{l}\text { Dependent variable: } \\
\text { WTP } 2012\end{array}$} & \multicolumn{2}{|c|}{$\begin{array}{l}\text { Friends and family } \\
\text { (FF), unidirectional }\end{array}$} & \multicolumn{2}{|c|}{$\begin{array}{l}\text { Friends and family } \\
\text { (FF), bidirectional }\end{array}$} & \multicolumn{2}{|c|}{$\begin{array}{l}\text { Agricultural contacts, } \\
\text { bidirectional }\end{array}$} \\
\hline & (1) & $(2)$ & (3) & (4) & (5) & (6) \\
\hline $\begin{array}{l}\text { At least one adopter in } \\
\text { network }\end{array}$ & $\begin{array}{c}20.68 \\
(31.88)\end{array}$ & & $\begin{array}{c}18.01 \\
(25.58)\end{array}$ & & $\begin{array}{c}42.60 \\
(28.69)\end{array}$ & \\
\hline $\begin{array}{l}\text { At least one adopter in } \\
\text { network (water-savers) }\end{array}$ & & $\begin{array}{l}50.45 \\
(37.24) \\
{[0.054]}\end{array}$ & & $\begin{array}{l}57.41^{*} \\
(30.51) \\
{[0.142]}\end{array}$ & & $\begin{array}{c}103.75^{* * *} \\
(34.74) \\
{[0.006]}\end{array}$ \\
\hline $\begin{array}{l}\text { At least one adopter in } \\
\text { network (nonsavers) }\end{array}$ & & $\begin{array}{l}-52.76 \\
(39.46)\end{array}$ & & $\begin{array}{l}-23.04 \\
(31.65)\end{array}$ & & $\begin{array}{l}-30.68 \\
(34.10)\end{array}$ \\
\hline $\begin{array}{l}\text { Control for number of would } \\
\text { be adopters, dummy variables }\end{array}$ & Yes & & Yes & & Yes & \\
\hline $\begin{array}{l}\text { Control for number of } \\
\text { qualifying farmers (water- } \\
\text { savers), dummy variables }\end{array}$ & & Yes & & Yes & & Yes \\
\hline $\begin{array}{l}\text { Control for number of } \\
\text { qualifying farmers } \\
\text { (nonsavers), dummy variables }\end{array}$ & & Yes & & Yes & & Yes \\
\hline Total network size & $\begin{array}{c}-8.37 \\
(11.95)\end{array}$ & $\begin{array}{l}-14.06 \\
(11.88)\end{array}$ & $\begin{array}{l}-6.53 \\
(9.11)\end{array}$ & $\begin{array}{l}-8.58 \\
(8.79)\end{array}$ & $\begin{array}{c}-1.91 \\
(11.32)\end{array}$ & $\begin{array}{c}1.02 \\
(11.58)\end{array}$ \\
\hline Age (years) & $\begin{array}{l}-0.90 \\
(6.06)\end{array}$ & $\begin{array}{l}-0.45 \\
(5.97)\end{array}$ & $\begin{array}{c}0.47 \\
(6.04)\end{array}$ & $\begin{array}{l}-3.76 \\
(6.03)\end{array}$ & $\begin{array}{l}-2.66 \\
(6.05)\end{array}$ & $\begin{array}{l}-2.31 \\
(5.95)\end{array}$ \\
\hline Education (years) & $\begin{array}{c}0.65 \\
(1.83)\end{array}$ & $\begin{array}{c}1.24 \\
(1.83)\end{array}$ & $\begin{array}{c}0.48 \\
(1.85)\end{array}$ & $\begin{array}{c}0.40 \\
(1.85)\end{array}$ & $\begin{array}{c}0.18 \\
(1.81)\end{array}$ & $\begin{array}{c}0.30 \\
(1.80)\end{array}$ \\
\hline Wealth index & $\begin{array}{c}10.83 \\
(11.14)\end{array}$ & $\begin{array}{c}12.23 \\
(10.62)\end{array}$ & $\begin{array}{c}12.00 \\
(10.99)\end{array}$ & $\begin{array}{l}19.49^{*} \\
(10.85)\end{array}$ & $\begin{array}{c}9.25 \\
(10.95)\end{array}$ & $\begin{array}{c}8.33 \\
(11.02)\end{array}$ \\
\hline WTP 2011 (Rs./hour) & $\begin{array}{c}0.27 * * * \\
(0.05)\end{array}$ & $\begin{array}{c}0.25 * * * \\
(0.05)\end{array}$ & $\begin{array}{c}0.27^{* * *} \\
(0.05)\end{array}$ & $\begin{array}{c}0.26 * * * \\
(0.05)\end{array}$ & $\begin{array}{c}0.26 * * * \\
(0.05)\end{array}$ & $\begin{array}{c}0.25 * * * \\
(0.05)\end{array}$ \\
\hline Constant & $\begin{array}{c}253.63^{* * *} \\
(37.20)\end{array}$ & $\begin{array}{c}254.52^{* * *} \\
(36.57)\end{array}$ & $\begin{array}{c}247.58^{* * *} \\
(37.53)\end{array}$ & $\begin{array}{c}273.17^{* * *} \\
(37.44)\end{array}$ & $\begin{array}{c}248.43^{* * *} \\
(36.24)\end{array}$ & $\begin{array}{c}251.05^{* * *} \\
(35.94)\end{array}$ \\
\hline Observations & 422 & 422 & 422 & 422 & 422 & 422 \\
\hline R-squared & 0.09 & 0.12 & 0.10 & 0.12 & 0.11 & 0.14 \\
\hline
\end{tabular}

Notes: Water-saving denotes using at least 10\% less water in 2011-2012 than in 2010-2011. OLS regressions. Standard errors in parenthesis; ${ }^{* * *} \mathrm{p}<0.01,{ }^{* *} \mathrm{p}<0.05,{ }^{*} \mathrm{p}<0.1$. P-values for difference between effect of watersaver and nonsaving network contacts are in brackets. Wealth index consists of house condition; ration card possession; landholdings; and ownership of cell phones, vehicles, TVs, satellite dish, and livestock. 
APPENDIX E: Results using only farmers with at least one in-network qualifying farmer

Table E1-Network effects on demand for LLL

\begin{tabular}{|c|c|c|c|c|}
\hline Dependent variable: WTP 2012 & $(1)$ & $(2)$ & (3) & (4) \\
\hline At least one adopter in network & $\begin{array}{l}95.59 * * \\
(39.61)\end{array}$ & $\begin{array}{l}78.06 * * \\
(38.10)\end{array}$ & & \\
\hline $\begin{array}{l}\text { At least one adopter in network } \\
\text { (water savers) }\end{array}$ & & & $\begin{array}{c}151.18 * * * \\
(49.92) \\
{[0.037]}\end{array}$ & $\begin{array}{c}144.36 * * * \\
(47.49) \\
{[0.020]}\end{array}$ \\
\hline $\begin{array}{l}\text { At least one adopter in network } \\
\text { (nonsavers) }\end{array}$ & & & $\begin{array}{c}-2.03 \\
(53.76)\end{array}$ & $\begin{array}{l}-18.24 \\
(51.30)\end{array}$ \\
\hline One qualifying farmer in network & $\begin{array}{c}-550.16 * * \\
(259.57)\end{array}$ & $\begin{array}{l}-469.08^{*} \\
(251.44)\end{array}$ & & \\
\hline Two qualifying farmers in network & $\begin{array}{c}-538.50 * * \\
(237.41)\end{array}$ & $\begin{array}{c}-472.49 * * \\
(228.08)\end{array}$ & & \\
\hline Three qualifying farmers in network & $\begin{array}{c}-487.35^{* *} \\
(225.98)\end{array}$ & $\begin{array}{l}-412.00^{*} \\
(215.61)\end{array}$ & & \\
\hline $\begin{array}{l}\text { One qualifying farmer in network } \\
\text { (water savers) }\end{array}$ & & & $\begin{array}{c}14.10 \\
(55.62)\end{array}$ & $\begin{array}{c}-2.13 \\
(55.53)\end{array}$ \\
\hline $\begin{array}{l}\text { Two qualifying farmers in network } \\
\text { (water savers) }\end{array}$ & & & $\begin{array}{l}-48.26 \\
(97.50)\end{array}$ & $\begin{array}{c}-71.71 \\
(100.38)\end{array}$ \\
\hline $\begin{array}{l}\text { Three qualifying farmers in network } \\
\text { (water-savers) }\end{array}$ & & & $\begin{array}{c}102.14 \\
(253.17)\end{array}$ & $\begin{array}{c}36.37 \\
(248.48)\end{array}$ \\
\hline $\begin{array}{l}\text { One qualifying farmer in network } \\
\text { (nonsavers) }\end{array}$ & & & $\begin{array}{c}92.82 \\
(56.76)\end{array}$ & $\begin{array}{c}72.40 \\
(56.72)\end{array}$ \\
\hline $\begin{array}{l}\text { Two qualifying farmers in network } \\
\text { (water-savers) }\end{array}$ & & & $\begin{array}{c}117.61 \\
(102.03)\end{array}$ & $\begin{array}{c}95.80 \\
(100.25)\end{array}$ \\
\hline $\begin{array}{l}\text { Three qualifying farmers in network } \\
\text { (water-savers) }\end{array}$ & & & $\begin{array}{c}120.96 \\
(205.31)\end{array}$ & $\begin{array}{c}190.25 \\
(200.71)\end{array}$ \\
\hline $\begin{array}{l}\text { Four qualifying farmers in network } \\
\text { (water-savers) }\end{array}$ & & & $\begin{array}{l}644.93^{* *} \\
(291.23)\end{array}$ & $\begin{array}{l}547.50 * \\
(285.71)\end{array}$ \\
\hline Total network size & $\begin{array}{l}-51.93^{*} \\
(27.06)\end{array}$ & $\begin{array}{l}-44.29 * \\
(26.14)\end{array}$ & $\begin{array}{l}-44.79 \\
(28.98)\end{array}$ & $\begin{array}{l}-37.06 \\
(28.16)\end{array}$ \\
\hline Age (10 years) & & $\begin{array}{c}9.62 \\
(10.12)\end{array}$ & & $\begin{array}{l}10.93 \\
(9.96)\end{array}$ \\
\hline Education (years) & & $\begin{array}{l}-3.41 \\
(3.11)\end{array}$ & & $\begin{array}{l}-2.36 \\
(3.04)\end{array}$ \\
\hline Wealth index & & $\begin{array}{c}9.60 \\
(14.54)\end{array}$ & & $\begin{array}{c}9.38 \\
(14.20)\end{array}$ \\
\hline WTP 2011 (Rs. 100/hour) & & $\begin{array}{c}0.27^{* * *} \\
(0.08)\end{array}$ & & $\begin{array}{c}0.27^{* * *} \\
(0.08)\end{array}$ \\
\hline Constant & $\begin{array}{c}919.89 * * * \\
(283.95)\end{array}$ & $\begin{array}{l}750.41 * * * \\
(275.46)\end{array}$ & $\begin{array}{c}315.45^{* * *} \\
(50.62)\end{array}$ & $\begin{array}{c}229.81^{* * * *} \\
(85.08)\end{array}$ \\
\hline Observations & 150 & 150 & 150 & 150 \\
\hline \multicolumn{5}{|c|}{$\begin{array}{l}\text { Notes: Water-saving denotes using } 14 \text { percent less water in } 2011-2012 \text { than in } 2010-2011 \text {. IV } \\
\text { model with lottery winning farmers instrumenting for farmers receiving leveling. Standard errors } \\
\text { in parenthesis; } * * * p<0.01, * * p<0.05, * p<0.1 \text {. P-values for difference between effect of water- } \\
\text { saver and nonsaving network contacts are in brackets. }\end{array}$} \\
\hline
\end{tabular}


Table E2-Network effects on demand at various prices

\begin{tabular}{|c|c|c|c|c|c|c|c|c|}
\hline Dependent variable: WTP 2012 & $\begin{array}{c}(1) \\
\text { Rs. } 250\end{array}$ & $\begin{array}{c}(2) \\
\text { Rs.350 }\end{array}$ & $\begin{array}{c}(3) \\
\text { Rs.500 } \\
\end{array}$ & $\begin{array}{c}(4) \\
\text { Rs. } 600 \\
\end{array}$ & $\begin{array}{c}(5) \\
\text { Rs. } 250\end{array}$ & $\begin{array}{c}(6) \\
\text { Rs. } 350\end{array}$ & $\begin{array}{c}(7) \\
\text { Rs.500 }\end{array}$ & $\begin{array}{c}(8) \\
\text { Rs. } 600 \\
\end{array}$ \\
\hline \multirow[t]{2}{*}{ At least one adopter in network } & $0.15^{*}$ & $0.25 * *$ & 0.07 & 0.04 & & & & \\
\hline & $(0.08)$ & $(0.10)$ & $(0.08)$ & $(0.06)$ & & & & \\
\hline \multirow[t]{3}{*}{ At least one adopter in network (water savers) } & & & & & $0.27^{* * *}$ & $0.28 * *$ & $0.19 *$ & $0.16^{* *}$ \\
\hline & & & & & $(0.09)$ & $(0.13)$ & $(0.10)$ & $(0.08)$ \\
\hline & & & & & {$[0.026]$} & {$[0.435]$} & {$[0.092]$} & [0.034] \\
\hline \multirow{2}{*}{ At least one adopter in network (nonsavers) } & & & & & -0.04 & 0.13 & -0.06 & -0.08 \\
\hline & & & & & (0.10) & $(0.14)$ & $(0.11)$ & $(0.08)$ \\
\hline $\begin{array}{l}\text { Controls for number of qualifying farmers in } \\
\text { network }\end{array}$ & Yes & Yes & Yes & Yes & & & & \\
\hline $\begin{array}{l}\text { Controls for number of qualifying water saving } \\
\text { farmers in network }\end{array}$ & & & & & Yes & Yes & Yes & Yes \\
\hline $\begin{array}{l}\text { Controls for number of qualifying nonsaving } \\
\text { farmers in network }\end{array}$ & & & & & Yes & Yes & Yes & Yes \\
\hline \multirow[t]{2}{*}{ Total network size } & -0.05 & $-0.14 * *$ & -0.07 & -0.05 & -0.03 & -0.11 & -0.07 & -0.05 \\
\hline & $(0.05)$ & $(0.07)$ & $(0.05)$ & $(0.04)$ & $(0.06)$ & $(0.08)$ & $(0.06)$ & $(0.05)$ \\
\hline \multirow[t]{2}{*}{ Age (10 years) } & 0.03 & 0.02 & 0.00 & -0.00 & $0.04 *$ & 0.01 & 0.00 & 0.00 \\
\hline & $(0.02)$ & $(0.03)$ & $(0.02)$ & $(0.02)$ & $(0.02)$ & $(0.03)$ & $(0.02)$ & $(0.02)$ \\
\hline \multirow[t]{2}{*}{ Education (years) } & -0.00 & 0.00 & $-0.02 * *$ & $-0.01 *$ & 0.00 & 0.00 & $-0.01 * *$ & $-0.01 *$ \\
\hline & $(0.01)$ & $(0.01)$ & $(0.01)$ & $(0.01)$ & $(0.01)$ & $(0.01)$ & $(0.01)$ & $(0.00)$ \\
\hline \multirow[t]{2}{*}{ Wealth index } & 0.04 & 0.01 & 0.00 & -0.00 & 0.04 & 0.01 & -0.00 & -0.01 \\
\hline & $(0.03)$ & $(0.04)$ & $(0.03)$ & $(0.02)$ & $(0.03)$ & $(0.04)$ & $(0.03)$ & $(0.02)$ \\
\hline \multirow[t]{2}{*}{ WTP 2011 (Rs. 100/hour) } & 0.02 & $0.06 * * *$ & $0.04 * * *$ & $0.05^{* * *}$ & 0.02 & $0.06 * * *$ & $0.05 * * *$ & $0.06 * * *$ \\
\hline & $(0.02)$ & $(0.02)$ & $(0.02)$ & $(0.01)$ & $(0.02)$ & $(0.02)$ & $(0.02)$ & $(0.01)$ \\
\hline \multirow[t]{2}{*}{ Constant } & $0.99 *$ & $1.50 * *$ & $1.44^{* *}$ & $1.19 * * *$ & $0.50 * * *$ & 0.32 & 0.22 & 0.16 \\
\hline & $(0.56)$ & $(0.73)$ & $(0.56)$ & $(0.44)$ & $(0.17)$ & $(0.23)$ & $(0.18)$ & $(0.14)$ \\
\hline Observations & 150 & 150 & 150 & 150 & 150 & 150 & 150 & 150 \\
\hline
\end{tabular}

Notes: Water-saving denotes using 14 percent less water in 2011-2012 than in 2010-2011. IV model with lottery winning farmers instrumenting for farmers receiving leveling. Standard errors in parenthesis; ${ }^{* *} p<0.01, * * p<0.05, * p<0.1$. P-values for difference between effect of water-saver and nonsaving network contacts are in brackets. 
Table E3-Network effects on mode of exposure to LLL

\begin{tabular}{|c|c|c|c|c|c|c|}
\hline \multirow[t]{2}{*}{ Exposure to LLL through... } & \multicolumn{2}{|c|}{$\begin{array}{l}\text {... conversation with } \\
\text { adopting farmer about LLL }\end{array}$} & \multicolumn{2}{|c|}{$\begin{array}{l}\text {...seeing LLL unit } \\
\text { operate }\end{array}$} & \multicolumn{2}{|c|}{$\begin{array}{l}\text {...observing field of } \\
\text { adopting farmer }\end{array}$} \\
\hline & $(1)$ & $(2)$ & $(3)$ & (4) & (5) & $(6)$ \\
\hline $\begin{array}{l}\text { At least one adopter in } \\
\text { network }\end{array}$ & $\begin{array}{l}0.16^{*} \\
(0.10)\end{array}$ & & $\begin{array}{c}0.09 \\
(0.11)\end{array}$ & & $\begin{array}{c}0.29 * * * \\
(0.10)\end{array}$ & \\
\hline $\begin{array}{l}\text { At least one adopter in } \\
\text { network (water savers) }\end{array}$ & & $\begin{array}{c}0.10 \\
(0.13) \\
{[0.876]}\end{array}$ & & $\begin{array}{c}0.03 \\
(0.14) \\
{[0.948]}\end{array}$ & & $\begin{array}{c}0.13 \\
(0.13) \\
{[0.364]}\end{array}$ \\
\hline $\begin{array}{l}\text { At least one adopter in } \\
\text { network (nonsavers) }\end{array}$ & & $\begin{array}{c}0.13 \\
(0.14)\end{array}$ & & $\begin{array}{c}0.05 \\
(0.15)\end{array}$ & & $\begin{array}{r}0.29 * * \\
(0.14)\end{array}$ \\
\hline $\begin{array}{l}\text { One qualifying farmer in } \\
\text { network }\end{array}$ & $\begin{array}{l}0.16^{*} \\
(0.10)\end{array}$ & & $\begin{array}{c}0.09 \\
(0.11)\end{array}$ & & $\begin{array}{c}0.29 * * * \\
(0.10)\end{array}$ & \\
\hline $\begin{array}{l}\text { Two qualifying farmers in } \\
\text { network }\end{array}$ & $\begin{array}{l}-0.20 \\
(0.63)\end{array}$ & & $\begin{array}{l}-0.22 \\
(0.70)\end{array}$ & & $\begin{array}{c}1.71^{* * *} \\
(0.66)\end{array}$ & \\
\hline $\begin{array}{l}\text { Three qualifying farmers in } \\
\text { network }\end{array}$ & $\begin{array}{l}-0.36 \\
(0.58)\end{array}$ & & $\begin{array}{l}-0.33 \\
(0.63)\end{array}$ & & $\begin{array}{c}1.57^{* * *} \\
(0.60)\end{array}$ & \\
\hline $\begin{array}{l}\text { One qualifying farmer in } \\
\text { network (water savers) }\end{array}$ & & $\begin{array}{c}0.01 \\
(0.14)\end{array}$ & & $\begin{array}{c}0.03 \\
(0.16)\end{array}$ & & $\begin{array}{l}-0.09 \\
(0.15)\end{array}$ \\
\hline $\begin{array}{l}\text { Two qualifying farmers in } \\
\text { network (water savers) }\end{array}$ & & $\begin{array}{l}-0.04 \\
(0.25)\end{array}$ & & $\begin{array}{l}-0.13 \\
(0.28)\end{array}$ & & $\begin{array}{l}-0.29 \\
(0.26)\end{array}$ \\
\hline $\begin{array}{l}\text { Three qualifying farmers in } \\
\text { network (water savers) }\end{array}$ & & $\begin{array}{c}0.41 \\
(0.65)\end{array}$ & & $\begin{array}{c}0.32 \\
(0.70)\end{array}$ & & $\begin{array}{l}-0.46 \\
(0.67)\end{array}$ \\
\hline $\begin{array}{l}\text { One qualifying farmer in } \\
\text { network (nonsavers) }\end{array}$ & & $\begin{array}{l}-0.08 \\
(0.15)\end{array}$ & & $\begin{array}{c}0.07 \\
(0.16)\end{array}$ & & $\begin{array}{l}-0.22 \\
(0.15)\end{array}$ \\
\hline $\begin{array}{l}\text { Two qualifying farmers in } \\
\text { network (water-savers) }\end{array}$ & & $\begin{array}{c}0.00 \\
(0.26)\end{array}$ & & $\begin{array}{c}0.02 \\
(0.28)\end{array}$ & & $\begin{array}{l}-0.51^{*} \\
(0.27)\end{array}$ \\
\hline $\begin{array}{l}\text { Three qualifying farmers in } \\
\text { network (water-savers) }\end{array}$ & & $\begin{array}{l}-0.51 \\
(0.53)\end{array}$ & & $\begin{array}{c}0.40 \\
(0.58)\end{array}$ & & $\begin{array}{l}-1.05^{*} \\
(0.55)\end{array}$ \\
\hline $\begin{array}{l}\text { Four qualifying farmers in } \\
\text { network (water-savers) }\end{array}$ & & $\begin{array}{c}0.44 \\
(0.74)\end{array}$ & & $\begin{array}{c}0.33 \\
(0.80)\end{array}$ & & $\begin{array}{c}-1.98^{* * *} \\
(0.77)\end{array}$ \\
\hline Total network size & $\begin{array}{c}0.02 \\
(0.07)\end{array}$ & $\begin{array}{l}-0.02 \\
(0.07)\end{array}$ & $\begin{array}{c}0.02 \\
(0.07)\end{array}$ & $\begin{array}{c}0.01 \\
(0.08)\end{array}$ & $\begin{array}{l}0.17^{* *} \\
(0.07)\end{array}$ & $\begin{array}{l}0.18^{* *} \\
(0.08)\end{array}$ \\
\hline Age (10 years) & $\begin{array}{c}0.08^{* * *} \\
(0.03)\end{array}$ & $\begin{array}{c}0.07^{* * *} \\
(0.03)\end{array}$ & $\begin{array}{l}-0.02 \\
(0.03)\end{array}$ & $\begin{array}{l}-0.02 \\
(0.03)\end{array}$ & $\begin{array}{c}0.02 \\
(0.03)\end{array}$ & $\begin{array}{c}0.01 \\
(0.03)\end{array}$ \\
\hline Education (years) & $\begin{array}{r}0.02 * * \\
(0.01)\end{array}$ & $\begin{array}{l}0.01^{*} \\
(0.01)\end{array}$ & $\begin{array}{c}0.01 \\
(0.01)\end{array}$ & $\begin{array}{c}0.01 \\
(0.01)\end{array}$ & $\begin{array}{c}0.00 \\
(0.01)\end{array}$ & $\begin{array}{c}0.00 \\
(0.01)\end{array}$ \\
\hline Constant & $\begin{array}{c}0.28 \\
(0.70)\end{array}$ & $\begin{array}{c}0.20 \\
(0.22)\end{array}$ & $\begin{array}{c}0.81 \\
(0.77)\end{array}$ & $\begin{array}{l}0.51^{* *} \\
(0.24)\end{array}$ & $\begin{array}{c}-1.75^{* *} \\
(0.72)\end{array}$ & $\begin{array}{c}0.17 \\
(0.23)\end{array}$ \\
\hline Observations & 150 & 150 & 150 & 150 & 150 & 150 \\
\hline
\end{tabular}

Notes: Water-saving denotes using 14 percent less water in 2011-2012 than in 2010-2011. IV linear probability model with lottery winning farmers instrumenting for farmers receiving leveling. Standard errors in parenthesis; ${ }^{* * *} \mathrm{p}<0.01,{ }^{* *} \mathrm{p}<0.05, * \mathrm{p}<0.1$. P-values for difference between effect of water-saver and nonsaving network contacts are in brackets. 
Table E4-Placebo test for spurious network effects

\begin{tabular}{|c|c|c|c|c|}
\hline Dependent variable: WTP 2011 & (1) & $(2)$ & (3) & (4) \\
\hline At least one adopter in network & $\begin{array}{c}28.11 \\
(39.62)\end{array}$ & $\begin{array}{c}36.73 \\
(39.02)\end{array}$ & & \\
\hline At least one adopter in network (water-savers) & & & $\begin{array}{l}-21.42 \\
(51.32) \\
{[0.362]}\end{array}$ & $\begin{array}{l}-20.21 \\
(50.53) \\
{[0.705]}\end{array}$ \\
\hline At least one adopter in network (nonsavers) & & & $\begin{array}{c}47.46 \\
(55.28)\end{array}$ & $\begin{array}{c}39.94 \\
(54.35)\end{array}$ \\
\hline One qualifying farmer in network & $\begin{array}{l}-319.68 \\
(259.62)\end{array}$ & $\begin{array}{l}-255.73 \\
(258.55)\end{array}$ & & \\
\hline Two qualifying farmers in network & $\begin{array}{l}-212.69 \\
(237.46)\end{array}$ & $\begin{array}{l}-170.45 \\
(234.82)\end{array}$ & & \\
\hline Three qualifying farmers in network & $\begin{array}{l}-265.92 \\
(226.02)\end{array}$ & $\begin{array}{l}-238.34 \\
(221.51)\end{array}$ & & \\
\hline One qualifying farmer in network (water savers) & & & $\begin{array}{l}111.48^{*} \\
(57.19)\end{array}$ & $\begin{array}{c}95.69 \\
(58.65)\end{array}$ \\
\hline Two qualifying farmers in network (water savers) & & & $\begin{array}{l}171.37^{*} \\
(100.25)\end{array}$ & $\begin{array}{c}113.24 \\
(106.39)\end{array}$ \\
\hline $\begin{array}{l}\text { Three qualifying farmers in network (water- } \\
\text { savers) }\end{array}$ & & & $\begin{array}{c}377.67 \\
(260.31)\end{array}$ & $\begin{array}{c}300.40 \\
(263.16)\end{array}$ \\
\hline One qualifying farmer in network (nonsavers) & & & $\begin{array}{l}112.51^{*} \\
(58.36)\end{array}$ & $\begin{array}{l}101.48 * \\
(59.69)\end{array}$ \\
\hline Two qualifying farmers in network (water-savers) & & & $\begin{array}{c}109.39 \\
(104.91)\end{array}$ & $\begin{array}{c}95.40 \\
(106.23)\end{array}$ \\
\hline $\begin{array}{l}\text { Three qualifying farmers in network (water- } \\
\text { savers) }\end{array}$ & & & $\begin{array}{l}-104.11 \\
(211.10)\end{array}$ & $\begin{array}{l}-78.55 \\
(213.00)\end{array}$ \\
\hline Four qualifying farmers in network (water-savers) & & & $\begin{array}{c}400.72 \\
(299.45)\end{array}$ & $\begin{array}{c}331.94 \\
(302.31)\end{array}$ \\
\hline Total network size & $\begin{array}{l}-21.24 \\
(27.06)\end{array}$ & $\begin{array}{l}-13.79 \\
(26.93)\end{array}$ & $\begin{array}{l}-20.97 \\
(29.80)\end{array}$ & $\begin{array}{l}-12.61 \\
(29.89)\end{array}$ \\
\hline Age (years) & & $\begin{array}{c}8.24 \\
(10.42)\end{array}$ & & $\begin{array}{c}9.07 \\
(10.55)\end{array}$ \\
\hline Education (years) & & $\begin{array}{c}3.29 \\
(3.19)\end{array}$ & & $\begin{array}{c}3.71 \\
(3.22)\end{array}$ \\
\hline Wealth index & & $\begin{array}{l}26.54^{*} \\
(14.82)\end{array}$ & & $\begin{array}{c}21.67 \\
(14.97)\end{array}$ \\
\hline Constant & $\begin{array}{l}541.79 * \\
(284.00)\end{array}$ & $\begin{array}{c}397.57 \\
(282.38)\end{array}$ & $\begin{array}{c}119.54 * * \\
(52.05)\end{array}$ & $\begin{array}{c}49.33 \\
(90.24)\end{array}$ \\
\hline Observations & 150 & 150 & 150 & 150 \\
\hline
\end{tabular}

Notes: Water-saving denotes using at least 10\% less water in 2011-2012 than in 2010-2011. IV regressions with lottery winning farmers instrumenting for farmers receiving leveling. Standard errors in parenthesis; $* * * p<0.01$, $* * p<0.05, * p<0.1$. P-values for difference between effect of water-saver and nonsaving network contacts are in brackets. Wealth index consists of house condition; ration card possession; landholdings; and ownership of cell phones, vehicles, TVs, satellite dish, and livestock. 
Table E5-Network effects using alternate network types

\begin{tabular}{|c|c|c|c|c|c|c|}
\hline \multirow[t]{2}{*}{$\begin{array}{l}\text { Dependent variable: } \\
\text { WTP } 2012\end{array}$} & \multicolumn{2}{|c|}{$\begin{array}{l}\text { Friends and family } \\
\text { (FF), unidirectional }\end{array}$} & \multicolumn{2}{|c|}{$\begin{array}{l}\text { Friends and family } \\
\text { (FF), bidirectional }\end{array}$} & \multicolumn{2}{|c|}{$\begin{array}{l}\text { Agricultural contacts, } \\
\text { bidirectional }\end{array}$} \\
\hline & $(1)$ & $(2)$ & (3) & (4) & (5) & (6) \\
\hline $\begin{array}{l}\text { At least one adopter in } \\
\text { network }\end{array}$ & $\begin{array}{l}18.12 \\
(35.56)\end{array}$ & & $\begin{array}{l}20.04 \\
(27.04)\end{array}$ & & $\begin{array}{c}37.61 \\
(33.76)\end{array}$ & \\
\hline $\begin{array}{l}\text { At least one adopter in } \\
\text { network (water-savers) }\end{array}$ & & $\begin{array}{c}40.54 \\
(38.20) \\
{[0.066]}\end{array}$ & & $\begin{array}{l}57.08^{*} \\
(30.42) \\
{[0.112]}\end{array}$ & & $\begin{array}{c}113.64 * * * \\
(37.94) \\
{[0.008]}\end{array}$ \\
\hline $\begin{array}{l}\text { At least one adopter in } \\
\text { network (nonsavers) }\end{array}$ & & $\begin{array}{l}-58.14 \\
(42.72)\end{array}$ & & $\begin{array}{l}-14.34 \\
(35.55)\end{array}$ & & $\begin{array}{l}-40.22 \\
(42.84)\end{array}$ \\
\hline $\begin{array}{l}\text { Control for number of would } \\
\text { be adopters, dummy variables }\end{array}$ & Yes & & Yes & & Yes & \\
\hline $\begin{array}{l}\text { Control for number of } \\
\text { qualifying farmers (water- } \\
\text { savers), dummy variables }\end{array}$ & & Yes & & Yes & & Yes \\
\hline $\begin{array}{l}\text { Control for number of } \\
\text { qualifying farmers } \\
\text { (nonsavers), dummy variables }\end{array}$ & & Yes & & Yes & & Yes \\
\hline Total network size & $\begin{array}{l}-16.30 \\
(14.75)\end{array}$ & $\begin{array}{l}-21.17 \\
(14.32)\end{array}$ & $\begin{array}{c}-6.75 \\
(11.02)\end{array}$ & $\begin{array}{c}-8.40 \\
(10.28)\end{array}$ & $\begin{array}{c}-6.24 \\
(13.30)\end{array}$ & $\begin{array}{c}-1.04 \\
(13.64)\end{array}$ \\
\hline Age (years) & $\begin{array}{c}0.48 \\
(8.97)\end{array}$ & $\begin{array}{c}1.08 \\
(8.59)\end{array}$ & $\begin{array}{c}0.02 \\
(7.16)\end{array}$ & $\begin{array}{l}-7.11 \\
(7.04)\end{array}$ & $\begin{array}{l}14.89^{*} \\
(8.75)\end{array}$ & $\begin{array}{l}12.82 \\
(8.58)\end{array}$ \\
\hline Education (years) & $\begin{array}{l}-2.62 \\
(2.83)\end{array}$ & $\begin{array}{l}-1.22 \\
(2.82)\end{array}$ & $\begin{array}{l}-2.82 \\
(2.23)\end{array}$ & $\begin{array}{l}-3.45 \\
(2.23)\end{array}$ & $\begin{array}{l}-0.92 \\
(2.64)\end{array}$ & $\begin{array}{l}-0.98 \\
(2.61)\end{array}$ \\
\hline Wealth index & $\begin{array}{c}4.12 \\
(13.81)\end{array}$ & $\begin{array}{c}6.84 \\
(12.43)\end{array}$ & $\begin{array}{c}10.75 \\
(12.09)\end{array}$ & $\begin{array}{l}21.07^{*} \\
(11.69)\end{array}$ & $\begin{array}{c}3.56 \\
(12.90)\end{array}$ & $\begin{array}{c}4.38 \\
(12.86)\end{array}$ \\
\hline WTP 2011 (Rs./hour) & $\begin{array}{c}0.27^{* * *} \\
(0.07)\end{array}$ & $\begin{array}{c}0.24 * * * \\
(0.07)\end{array}$ & $\begin{array}{c}0.26^{* * *} \\
(0.06)\end{array}$ & $\begin{array}{c}0.26^{* * *} \\
(0.06)\end{array}$ & $\begin{array}{c}0.26^{* * *} \\
(0.07)\end{array}$ & $\begin{array}{c}0.25^{* * *} \\
(0.07)\end{array}$ \\
\hline Constant & $\begin{array}{l}601.02 * \\
(336.01)\end{array}$ & $\begin{array}{c}272.63^{* * *} \\
(64.51)\end{array}$ & $\begin{array}{c}403.91 \\
(262.42)\end{array}$ & $\begin{array}{c}326.56^{* * *} \\
(52.98)\end{array}$ & $\begin{array}{l}412.43^{*} \\
\text { (236.54) }\end{array}$ & $\begin{array}{c}226.71^{* * * *} \\
(69.89)\end{array}$ \\
\hline Observations & 175 & 175 & 258 & 258 & 208 & 208 \\
\hline
\end{tabular}

